T.C.

HACETTEPE ÜNIVERSITESI

SAĞLIK BİLIMLERİ ENSTITÜSÜ

STABIL DURUMDAKİ KOAH HASTALARINDA SOLUNUM FONKSIYYONLARI, EGZERSİZ KAPASITESI, YAŞAM KALİTESİ, ANKSIYYETE İLE BİRLİKTE AĞRI, KAS KUVVETİ VE KEMIKK MINERAL YOĞUNLUĞUNUN İNCELENMESI

Fzt. Fatma Fulden ÇAKIR

Protez Ortez ve Biyomekani Programı

YÜKSEK LİSANS TEZI

ANKARA

2019 

T.C.

HACETTEPE ÜNIVERSITESI

SAĞLIK BILIIMLERİ ENSTITÜSÜ

STABIL DURUMDAKİ KOAH HASTALARINDA SOLUNUM FONKSIYYONLARI, EGZERSIZ KAPASITTESI, YAŞAM KALITESİ, ANKSIYYETE İLE BİRLİKTE AĞRI, KAS KUVVETİ VE KEMIKK MINNERAL YOĞUNLUĞUNUN İNCELENMESI

Fzt. Fatma Fulden ÇAKIR

Protez Ortez ve Biyomekani Programı

YÜKSEK LİSANS TEZI

TEZ DANIŞMANI

Prof. Dr. Filiz CAN

ANKARA

2019 


\section{ONAY SAYFASI}

\section{Stabil Durumdaki KOAH Hastalarında Solunum Fonksiyonları,Egzersiz}

Kapasitesi,Yaşam Kalitesi,Anksiyete İle Birlikte Ağrı, Kas Kuvveti Ve Kemik Mineral Yoğunluğunun İncelenmesi

Öğrenci: Fatma Fulden ÇAKIR

Danışman:Prof.Dr.Filiz Can

Bu tez çalışması 26.03.2019 tarihinde jürimiz tarafından "Protez-Ortez ve Biyomekani Programı” nda yüksek lisans tezi olarak kabul edilmiştir.

Jüri Başkanı:

Tez Danışmanı:

Üye:

Üye:

Üye:

$$
\begin{aligned}
& \text { Prof.Dr.Fatma Gül Yazıcıoğlu } \\
& \text { Hacettepe Üniveritesi } \\
& \text { Prof.Dr.Filiz Can } \\
& \text { Hacettepe Üniversitesi } \\
& \text { Prof.Dr.Serap H. Inal } \\
& \text { Bahçeşehir Üniversitesi } \\
& \text { Prof.Dr.Deniz Inal Ince } \\
& \text { Hacettepe Üniversitesi } \\
& \text { Prof.Dr.Zafer Erden } \\
& \text { Hacettepe Üniversitesi }
\end{aligned}
$$
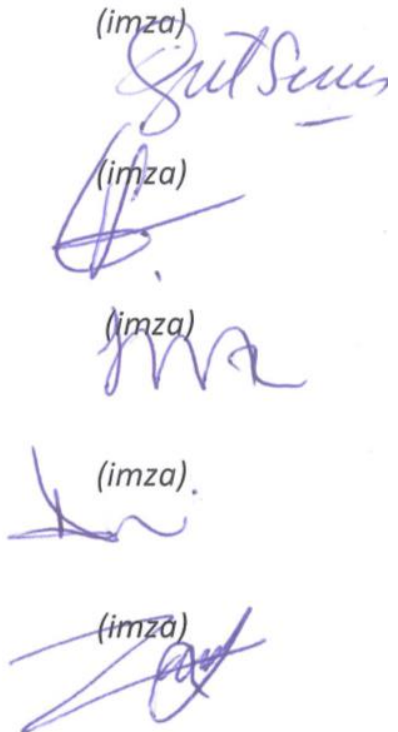

Bu tez Hacettepe Üniversitesi Lisansüstü Eğitim-Öğretim ve Sınav Yönetmeliğinin ilgili maddeleri uyarınca yukarıdaki jüri tarafından uygun bulunmuştur.

11 Nisan 2019

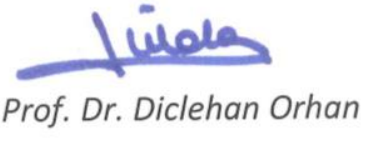

Enstitü Müdürü 


\section{YAYIMLAMA VE FIIKRİ MÜLIKIYET HAKLARI BEYANI}

Enstitü tarafından onaylanan lisansüstü tezimin/raporumun tamamını veya herhangi bir kısmını, basılı (kağıt) ve elektronik formatta arşivleme ve aşağıda verilen koşullarla kullanıma açma iznini Hacettepe Üniversitesine verdiğimi bildiririm. Bu izinle Üniversiteye verilen kullanım hakları dıșındaki tüm fikri mülkiyet haklarım bende kalacak, tezimin tamamının ya da bir bölümünün gelecekteki çalışmalarda (makale, kitap, lisans ve patent vb.) kullanım hakları bana ait olacaktır.

Tezin kendi orijinal çalışmam olduğunu, başkalarının haklarını ihlal etmediğimi ve tezimin tek yetkili sahibi olduğumu beyan ve taahhüt ederim. Tezimde yer alan telif hakkı bulunan ve sahiplerinden yazılı izin alınarak kullanılması zorunlu metinlerin yazılı izin alınarak kullandığımı ve istenildiğinde suretlerini Üniversiteye teslim etmeyi taahhüt ederim.

Yükseköğretim Kurulu tarafindan yayınlanan "Lisansüstü Tezlerin Elektronik Ortamda Toplanması, Düzenlenmesi ve Erişime Açılmasına İlişkin Yönerge" kapsamında tezim aşağıda belirtilen koşullar haricince YÖK Ulusal Tez Merkezi / H.Ü. Kütüphaneleri Açık Erişim Sisteminde erişime açılır.

○ Enstitü / Fakülte yönetim kurulu kararı ile tezimin erişime açılması mezuniyet tarihimden itibaren 2 yıl ertelenmiştir. ${ }^{(1)}$

○ Enstitü / Fakülte yönetim kurulunun gerekçeli kararı ile tezimin erişime açılması mezuniyet tarihimden itibaren .. ay ertelenmiştir. ${ }^{(2)}$

○ Tezimle ilgili gizlilik kararı verilmişt

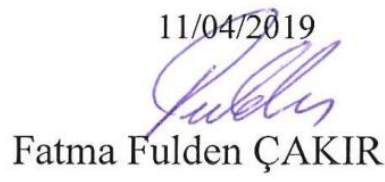

1 "Lisansüstü Tezlerin Elektronik Ortamda Toplanması, Düzenlenmesi ve Erişime Açılmasına İlişkin Yönerge”

(1) Madde 6. 1. Lisansüstü tezle ilgili patent başvurusu yapılması veya patent alma sürecinin devam etmesi durumunda tez danışmanının önerisi ve enstitü anabilim dalının uygun görüşü üzerine enstitü veya fakülte yönetim kurulu iki yıl süre ile tezin erişime açılmasının ertelenmesine karar verebilir.

(2) Madde 6. 2. Yeni teknik, materyal ve metotların kullanıldığı, henüz makaleye dönüssmemiş veya patent gibi yöntemlerle korunmamış ve internetten paylaşılması durumunda 3. şahıslara veya kurumlara haksız kazanç imkanı oluşturabilecek bilgi ve bulguları içeren tezler hakknnda tez danışmanının önerisi ve enstitü anabilim dalının uygun görüşü üzerine enstitü veya fakülte yönetim kurulunun gerekçeli kararı ile altı ayı aşmamak üzere tezin erişime açılması engellenebilir.

(3) Madde 7. 1. Ulusal çıkarlart veya güvenliği ilgilendiren, emniyet, istihbarat, savunma ve güvenlik, sağlık vb. konulara ilişkin lisansüstü tezlerle ilgili gizlilik kararı, tezin yapıldığı kurum tarafından verilir *. Kurum ve kuruluşlarla yapılan işbirliği protokolü çerçevesinde hazırlanan lisansüstü tezlere ilişkin gizlilik karart ise, ilgili kurum ve kuruluşun önerisi ile enstitü veya fakültenin uygun görüşü üzerine üniversite yönetim kurulu tarafindan verilir. Gizlilik kararı verilen tezler Yükseköğretim Kuruluna bildirilir. Madde 7.2. Gizlilik kararı verilen tezler gizlilik süresince enstitü veya fakülte tarafından gizlilik kuralları çerçevesinde muhafaza edilir, gizlilik kararının kaldırlması halinde Tez Otomasyon Sistemine yüklenir

* Tez danışmanının önerisi ve enstitü anabilim dalının uygun görüşü üzerine enstitü veya fakülte yönetim kurulu tarafindan karar verilir. 


\section{ETÍK BEYAN}

Bu çalışmadaki bütün bilgi ve belgeleri akademik kurallar çerçevesinde elde ettiğimi, görsel, işitsel ve yazılı tüm bilgi ve sonuçları bilimsel ahlak kurallarına uygun olarak sunduğumu, kullandığım verilerde herhangi bir tahrifat yapmadığımı, yararlandığım kaynaklara bilimsel normlara uygun olarak atıfta bulunduğumu, tezimin kaynak gösterilen durumlar dışında özgün olduğunu, Prof. Dr. Filiz CAN danışmanlığında tarafımdan üretildiğini ve Hacettepe Üniversitesi Sağlık Bilimleri Enstitüsü Tez Yazım Yönergesi’ne göre yazıldığını beyan ederim.

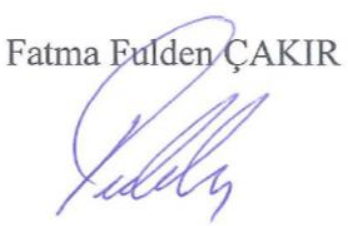




\section{TEŞEKKÜR}

Büyük bir emek ile gerçekleştirdiğim yüksek lisans tezimde başta danışmanım olarak çalışmanın oluşmasında, düzenlenmesinde, yürütülmesinde ve sonuçlanmasında bilgi ve deneyimleri ile bana destek olup katkıda bulunan, değerli fikirleriyle her zaman yol gösteren ve hayatımda da manevi desteğini esirgemeyen Prof. Dr. Filiz Can'a en içten teşekkürlerimi sunarım.

Bahçeşehir Üniversitesi Sağlı Bilimleri Fakültesi Fizik Tedavi ve Rehabilitasyon Bölüm Başkanı Prof. Dr. Serap İNAL'a bana her zaman vermiş olduğu destekleri ve değerli katkılarından dolayı yürekten teşekkür ederim. Ayrıca sevgili hocam Yrd. Doç. Dr. Dilber KARAGÖZOĞLU ÇOŞKUNSU'ya hayatımda her zaman yanımda olduğu için desteğinden dolayı sonsuz teşekkür ederim.

Çalışmamın gerçekleşmesinde ve hasta alımında büyük katkıları olan İstanbul Liv Hospital Hastanesi Göğüs Hastalıkları Polikliniği hekimleri, Prof. Dr. Ferah ECE ve Doç. Dr. Tuğçe HÜRKAL'a, her zaman yanımda olan çalışma arkadaşım Özge Nur BİLİM'e teşekkür ederim.

Tezimde yanımda olup, olumlu yaklaşımları ile beni güçlendiren değerli arkadaşlarım Uzm.Dyt.Ecenur ÖZKUL’a ,Uzm.Fzt.Pelin Pişirici, Uzm.Fzt.Çiçek Duman ve Uzm. Fzt. İpek İKİZ’e candan teşekkür ederim.

Beni yetiştiren bugünlerde olabilmem için hayatımın her aşamasında olduğu gibi tezimin de her aşamasında maddi ve manevi çok büyük emeği olan bana daima güç veren canım annem Tülin ŞAHMAN'a; her koşulda benimle olan babam Cengiz ŞAHMAN'a, tüm hayatımda ve tezimde büyük özveri ve emeği olan sevgili eşim Berke ÇAKIR ve yaşam kaynağım, en büyük şansım, canım kızım Melisa ÇAKIR'a sonsuz teşekkür ederim. 


\section{ÖZET}

Şahman Çakır F, Stabil durumdaki KOAH hastalarında solunum fonksiyonları, egzersiz kapasitesi, yaşam kalitesi, anksiyete ile birlikte ağrı, kas kuvveti ve kemik mineral yoğunluğunun incelenmesi, Hacettepe Üniversitesi, Sağlık Bilimleri Enstitüsü, Fizik Tedavi ve Rehabilitasyon Anabilim Dalı, Protez Ortez ve Biyomekanik Programı, Yüksek Lisans Tezi, Ankara, 2019. Kronik obstrüktif akciğer hastalığ $1(\mathrm{KOAH})$, akciğer kapasitesinde azalma ve hava yolu direncinde artma ile karakterize önemli mortalite ve morbiditeye sebep olan bir hastalıktır. Bu çalışmanın amacı; GOLD evre I ve II olan stabil durumdaki KOAH'lı hastalarda solunum fonksiyonları, egzersiz kapasitesi, yaşam kalitesi, anksiyete ile birlikte ağrı, kas kuvveti ve kemik mineral yoğunluğunun incelenmesidir. Çalışmaya 40-70 yıl yaş aralığında değişen klinik olarak stabil 40 KOAH'lı birey ve aynı yaş grubunda $35 \mathrm{KOAH}$ olmayan birey alınmıştır. KOAH'lı hastaların ve kontrol grubunun değerlendirilmesinde solunum fonksiyonları ve diffüzyon kapasiteleri spirometre ile, ağrı değerlendirmeleri vizüel analog skalası (VAS) ile, her iki grubun egzersiz kapasiteleri 6 Dakika Yürüme Testi (6DYT) ile, depresyon düzeyleri, Beck Depresyon Anketi ile, anksiyete düzeyleri Beck Anksiyete Ölçeği ile, yaşam kalitesi Sağlık Değerlendirme Anketi (HAQ) ve Kısa form SF36 anketleri ile, kemik mineral yoğunlukları ise kemik mineral dansitometrisi (BMD) ile değerlendirilmiştir. Çalışma sonucunda KOAH'lı hastaların solunum fonksiyon test değerleri tüm parametrelerinde $\left(\mathrm{FVC} \%, \mathrm{FEV}_{1} \%, \mathrm{FEV}_{1} / \mathrm{FVC} \%, \mathrm{FEF}_{25-75} \%\right)$, kontrol grubuna göre azalmıştır. $(\mathrm{p}<0,05)$ 6DYT sonuçları KOAH grubunda kontrol grubuna göre azalmıştır $(\mathrm{p}<0,001)$. Beck Anksiyete ve Beck Depresyon ölçeği KOAH grubunda kontrol grubuna göre daha yüksektir $(\mathrm{p}<0,001)$. 6DYT sonrası ağrı (VAS) ve istirahatte ağrı değerleri KOAH grubunda daha yüksek bulunmuştur $(p<0,05)$. KOAH ve kontrol gruplarının Gastroknemius ve Abdominal kas kuvveti KOAH grubunda kontrol grubuna göre daha düşük bulunmuştur $(\mathrm{p}<0,05)$. Hamstring, Kuadriseps ve Sırt Ekstansörler iki grup karşılaştırıldığında benzer bulunmuştur ( $p>0,05)$. Kemik mineral yoğunluğu da iki grupta benzer bulunmuştur $(p>0,05)$.

Sonuçlarımıza göre, stabil KOAH hastalarında pulmoner fonksiyonlar, egzersiz kapasitesi, yaşam kalitesi ve kas kuvveti azalırken, ağrı seviyesi, anksiyete ve depresyon düzeyleri artmıştır, postür ve kemik mineral yoğunluğunda ise $\mathrm{KOAH}$ grubunda azalması beklenirken, aksine fark görülmemiştir.

Anahtar Kelimeler: KOAH, ağrı, egzersiz kapasitesi, kemik mineral yoğunluğu, yaşam kalitesi 


\begin{abstract}
Şahman Çakır F, An analysis of respiratory function, exercise capacity, quality of life, anxiety, pain, muscle strength and bone mineral density in patients with stable COPD. Hacettepe University, Graduate school of Medical Sciences, Department of Physical Medicine and Rehabilitation, Prosthesis Orthesis and Biomechanics Programme, Master's Thesis, Ankara, 2019. Chronic Obstructive pulmonary disease is characterized by decreased lung capacity and increased airway resistance (COPD) and causes significant mortality and morbidity. The aim of this study was to examine pulmonary function, exercise capacity, quality of life, anxiety, pain, muscle strength, bone mineral density in patients with stable COPD. The study and control groups aged between 40 and 70 years consisted of 40 clinically in stable COPD patients with GOLD stage I and II and 35 non-COPD individuals, respectively. Before and after the treatment, the patients' pulmonary function and diffusion capacity were evaluated using a spirometer, pain assessments were performed using Numeric Pain Rating Scale (NPRS). Exercise capacity was evaluated using 6 Minute Walk Test (6MWT), depression levels were assessed using Beck Depression Inventory, anxiety levels were evaluated with Beck Anxiety Inventory, quality of life levels were evaluated using Health Assessment Questionnaire (HAQ) and Short From SF36 Survey, whereas bone mineral density was determined using Bone Mineral Densitometry (BMD). Our findings showed that all parameters of the respiratory function tests $\left(\mathrm{FVC} \%, \mathrm{FEV}_{1} \%, \mathrm{FEV}_{1} / \mathrm{FVC}, \mathrm{FEF}_{25-75} \%\right.$ ) of patients with $\mathrm{COPD}$ significantly decreased compared to the control group $(p<0.05)$. The difference between the SMWT of patients with COPD significantly decreased compared to the control group $(p<0.001)$. The differences in the Beck Anxiety Scale and the Beck Depression Scale of patients with COPD significantly increased compared to the control group $(\mathrm{p}<0.001, \mathrm{p}<0.05$, respectively). VAS after $6 \mathrm{MWT}$ and VAS at rest patients with COPD significantly increased compared to the control group $(p<0.001, p<0.05$, respectively). The gastrocnemius and abdominal muscle strengths of patients with COPD significantly decreased compared to the control group $(\mathrm{p}<0.05)$. The difference between Hamstring, Quadriceps and Back Extensors was not significant between the two groups $(\mathrm{p}>0.05)$. When the BMD was evaluated, there was no statistically significant difference in any of the variables between the COPD and the Control Groups ( $\mathrm{p}>0.05)$. According to our results, in stable COPD patients, pulmonary function, exercise capacity, quality of life and muscle strength decreased, whereas pain level, anxiety and depression level were increased, and contrary to expectations, there was no change in posture and BMD skores.
\end{abstract}

Keywords: COPD, pain, exercise capacity, bone mineral density, quality of life. 


\section{İÇINDEKILER}

$\begin{array}{ll}\text { ONAY SAYFASI } & \text { iii }\end{array}$

YAYIMLAMA VE FIKRİ MÜLKIYYT HAKLARI BEYANI iv

ETIK BEYAN $\mathrm{V}$

TEŞEKKÜR vi

ÖZET vii

ABSTRACT viii

İÇİNDEKİLER

SIMGELER VE KISALTMALAR xii

ŞEKİLLLER $\quad$ xvi

TABLOLAR Xvii

1. GÍRIŞ VE AMAÇ

2. GENEL BİLGILER 4

2.1. Kronik Obstrüktif Akciğer Hastalığı (KOAH) Risk Faktörleri 7

2.2. Kronik Obstrüktif Akciğer Hastalığının Patoloji, Patogenez ve Patofizyolojisi 9

2.3. Kronik Obstrüktif Akciğer Hastalığının Alt Tipleri 11

2.4. Kronik Obstrüktif Akciğer Hastalığının Semptomları ve Bulguları: 12

2.5. Kronik Obstrüktif Akciğer Hastalığında Değerlendirme 14

$\begin{array}{ll}\text { 2.5.1. Fizik Muayene } & 14\end{array}$

2.5.2. Spirometrik Değerlendirme 15

$\begin{array}{ll}\text { 2.5.3. Fizyoterapi Değerlendirmesi } & 17\end{array}$

3. BİREYLER VE YÖNTEM 20

3.1. Bireyler 20

3.2. Yöntem 21

3.3. Değerlendirme 21

3.3.1. Demografik Özellikler 22

3.3.2. Sosyodemografik Özellikler 22

3.3.3. Özgeçmiş 22

3.3.4. Alışkanlıklar 22

3.3.5.Ağrının Değerlendirilmesi 22

3.3.6. Postür Değerlendirilmesi 22

3.3.7. Solunum ve Kalp Hızı Değerlendirilmesi 22 
3.3.8. Kronik Obstrüktif Akciğer Hastalığı Semptomlarının Değerlendirilmesi 23

3.3.9. Solunum Testlerinin Değerlendirilmesi

3.3.10. Egzersiz Kapasitesinin Değerlendirilmesi 26

3.3.11. Kas Kuvvetinin Değerlendirilmesi 26

3.3.12. Anksiyete ve Depresyonun Değerlendirilmesi 26

3.3.13. Yaşam Kalitesinin Değerlendirilmesi 27

3.3.14. Kemik Mineral Yoğunluğu 27

3.4. İstatistiksel Analiz 27

4. BULGULAR 29

4.1. Demografik Özellikler 29

4.2. Sigara Tüketimi 30

4.3. Ağr1 31

4.4. Postür 32

4.5. Solunum Fonksiyon Testleri 32

4.6. Egzersiz Kapasitesi 33

4.7. Kas Kuvveti 34

4.8. Anksiyete- Depresyon 34

4.9. Yaşam Kalitesi 35

4.10. Kemik Mineral Yoğunluğu 36

4.11. Değerlendirme Parametrelerinin Etki Büyüklüklerinin Karşılaştırılması 37

5. TARTIŞMA 38

6. SONUÇLAR VE ÖNERILLER 54

7. KAYNAKLAR 56

\section{EKLER}

Ek 1. Modifiye MRC Dispne Skalası

Ek 2. KOAH Değerlendirme Anketi (COPD- Assessement Test=CAT)

Ek 3. St.George's Respiratory Questionnaire (SGRQ)

Ek 4. Beck Anksiyete Ölçeği

Ek 5. Beck Depresyon Ölçeği

Ek 6. Sağlık Değerlendirme Anketi HAQ

EK 7. SF-36 Yaşam Kalitesi Ölçeği

EK 8. Etik Kurul Formu 
EK 9. Orjinallik Ekran Çıktısı

EK 10. Dijital Makbuz

9. ÖZGEÇMIŞ 


\section{SIMGELER VE KISALTMALAR}

\begin{tabular}{|c|c|}
\hline$\$$ & Dolar \\
\hline$\%$ & Yüzde \\
\hline$\circ$ & Derece \\
\hline 6DYT & 6 Dakika Yürüme Testi \\
\hline $\mathbf{a}$ & Arter \\
\hline AAT & Alfa-1 antitripsin \\
\hline ABD & Amerika Birleşik Devletleri \\
\hline $\mathrm{ACE}$ & Angiotensin Converting Enzyme \\
\hline ACSM & American College of Sports Medicine \\
\hline AHA & American Heart Association \\
\hline ATP & Adenozin Trifosfat \\
\hline ATS & American Thoracic Society \\
\hline BAÖ & Beck Anksiyete Ölçeği \\
\hline BDI & Başlangıç Dispne İndeksi \\
\hline BDÖ & Beck Depresyon Ölçeği \\
\hline BT & Bilgisayarlı Tomografi \\
\hline CAT & COPD Assesment Test \\
\hline CIS & Checklist individual strength \\
\hline $\mathbf{c m}$ & Santimetre \\
\hline $\mathrm{cmH}_{2} \mathrm{O}$ & Santimetresu \\
\hline $\mathrm{CO}_{2}$ & Karbondioksit \\
\hline DALYs & The Disability-Adjusted Life Years \\
\hline DH & Dinamik Hiperinflasyon \\
\hline dk & Dakika \\
\hline DKB & Diyastolik Kan Basıncı \\
\hline DLCO & Diffüzyon Kapasitesi \\
\hline DSÖ & Dünya Sağlık Örgütü \\
\hline EELV & Ekspirasyon Sonrası Akciğer Volümü \\
\hline ERS & European Respiratory Society \\
\hline $\mathbf{F}$ & Tekrarlı Ölçümlerde Varyans Analizi Değeri \\
\hline FEF & Ekspiratuvar Akım Hizları \\
\hline FEF $_{25-75 \%}$ & Zorlu Vital Kapasitenin \% 25-75 Akım Hızı \\
\hline
\end{tabular}


FEV 1 Birinci Saniyedeki Zorlu Ekspiratuar Volüm

$\mathbf{F E V}_{\mathbf{1}} / \mathbf{F E V}_{\mathbf{6}}$ Bir saniyedeki zorlu ekspiratuvar volümün altı saniyedeki zorlu ekspiratuvar volume oranı

FEV $_{1}$ /FVC Birinci Saniyedeki Zorlu Ekspiratuar Volümün Zorlu Vital Kapasiteye Oran1

FEV $\quad$ Altı saniyedeki Zorlu Ekspiratuvar Volüm

FRC Fonksiyonel Rezidüel Kapasite

FVC Zorlu Vital Kapasite

GÇÖ Göğüs Çevre Ölçümleri

GOLD Global Initiative for Chronic Obstructive Lung Disease

GPB Glossofarenjiyal solunum

GST GlutatyonS-transferaz

GYA Günlük Yaşam Aktiviteleri

HAQ Health Assessment Questionnaire

Hz Hertz

IC İnspiratuar Kapasite

IRV İnspiratuar Rezerv Volüm

KAH Koroner Arter Hastalığ1

kg Kilogram

$\mathbf{k g} / \mathbf{m}^{2} \quad$ Kilogram/metrekare

kgF Kilogram-Kuvvet

KH Kalp Hizı

KOAH Kronik Obstrüktif Akciğer Hastalığ1

It Litre

M Musculus

m Metre

Max Maksimum

mEH Mikrozomal epokside hidrolaz

MEP Maksimal Ekspiratuar Basınç

MIP Maksimal İnspiratuar Basınç

Min Minimum

mlt Mililitre

mmHg Milimetre civa

MMRC Modifiye Medical Research Council Dispne Skalas1 


\begin{tabular}{|c|c|}
\hline MVV & Maksimum Volunter Ventilasyon \\
\hline $\mathbf{n}$ & Birey say1sı \\
\hline $\mathbf{N}$ & Newton \\
\hline NEADLS & Nottingham Extended Activities of Daily Living Scale \\
\hline $\mathbf{O}_{2}$ & Oksijen \\
\hline $\mathbf{p}$ & Yanılma Olasılığı \\
\hline PEF & Tepe Akım Hızı \\
\hline PEP & Pozitif ekspiratuar basınç \\
\hline PND & Paroksismal Noktürnal Dispne \\
\hline PR & Pulmoner Rehabilitasyon \\
\hline Sf & Solunum Frekans1 \\
\hline SF36 & Medical Outcome Kisaform \\
\hline SFT & Solunum fonksiyon testi \\
\hline SGRQ & St. George's Respiratory Questionnaire \\
\hline SK & Solunum Kontrolü \\
\hline SKB & Sistolik Kan Basıncı \\
\hline sn & Saniye \\
\hline $\mathrm{SpO}_{2}$ & Pulse Oksimetre ile Ölçülen Oksijen Satürasyonu \\
\hline SPSS & İstatistiksel Analiz Programı \\
\hline SS & Standart Sapma \\
\hline SVC & Yavaş Vital Kapasite \\
\hline $\mathbf{t}$ & İki Ortalama Arasındaki Farkın Önemlilik Testi Değeri \\
\hline TAK & Toplam Akciğer Kapasitesi \\
\hline TEE & Torakal Ekspansiyon Egzersizleri \\
\hline TLC & Total Akciğer Kapasitesi \\
\hline TNF & Tümör Nekroz Faktörü \\
\hline TV & Tidal Volü \\
\hline $\mathbf{v}$ & ven \\
\hline VAS & Vizüel Ağrı Skalası \\
\hline VC & Vital Kapasite \\
\hline $\mathrm{VCO}_{2}$ & Karbondioksit Üretimi \\
\hline $\mathbf{V}_{\mathbf{E}}$ & Dakika Ventilasyonu \\
\hline VKİ & Vücut Kitle İndeksi \\
\hline $\mathrm{VO}_{2}$ & Oksijen Tüketimi \\
\hline
\end{tabular}


VO2max Maksimal Oksijen Tüketimi

VT Tidal Volüm

X Aritmetik Ortalama

YLD Years of Healty Life Lost Due to Disability 


\section{ŞEKILLLER}

Şekil

Sayfa

2.1. KOAH'ın patogenezi (Marieb, E., Hoehn, K. (2017) Anatomy and

Physiology (5.bs) (İ. Tatar). İstanbul: Nobel Yayınevi. (2017) s:730.) 10

3.1. Solunum Fonksiyon Testi

25 


\section{TABLOLAR}

Tablo

Sayfa

2.1. KOAH'l1 hastalardaki kas güçsüzlüğünün nedenleri.

2.2. KOAH'lı hastalarda havayolu limitasyonu şiddeti sınıflandırılmasıGOLD 2017 (1) raporundan alınmıştır.

4.1. Grupların Demografik Özellikleri.

4.2. Grupların Sigara Tüketimi.

4.3. Grupların ağrı parametrelerinin karşılaştırılması.

4.4. Grupların Postür Parametrelerinin Karşılaştırılması.

4.5. Grupların Solunum Fonksiyon Test Parametrelerinin Karşılaştırılması. 33

4.6. Grupların egzersiz kapasitelerinin karşıllaştırılması.

4.7. Grupların kas kuvveti karşılaştırılması.

4.8. Grupların BECK Anksiyete Ölçeği ve BECK Depresyon Ölçeği Değerleri Karşılaştırmaları.

4.9. Grupların Yaşam Kalitesi Anketlerinin Karşılaştırılması.

4.10. Grupların Kemik Mineral Yoğunluğu Değerleri Karşılaştırılması. 


\section{GÍRİ̧̧ VE AMAÇ}

Kronik Obstrüktif Akciğer Hastalığı (KOAH), akciğer kapasitesinde azalma ve hava yolu direncinde artma ile karakterize, kronik ilerleyici bir akciğer hastalığıdır (1). KOAH akciğer fonksiyonları üzerine olan bu karakteristik özellikleri ile kısmen geri döndürülebilir ve tedavi edilebilir bir hastalık olarak düşünülmesine rağmen, ilerleyen durumlarda akut respiratuvar yetmezliğe kadar giden ve tüm toplumlarda yüksek mortalite ve morbilite oranına sahip olan kronik bir hastalıktır. KOAH'lı hastalarda görülen alveoler hipoventilasyon, ölü boşluk hiperventilasyonu, ventilasyon-perfüzyon ilişkisindeki bozulma ve sonucunda ortaya çıkan hipoksemi, akciğer fonksiyonlarında negatif etkilere yol açar. Hastalarda akciğerin iş yükü ve ventilasyonun litre cinsinden işi artar. Buna bağlı olarak bireylerde solunum yetersizliği, efor dispnesi ve fiziksel kapasitede azalma ortaya çıkar (2).

KOAH'lı hastaların çoğu, basit aktiviteler sırasında bile ortaya çıkan efor dispnesi nedeniyle günlük yaşam aktivitelerini yapmakta zorluk çeker ve gelişen hareket korkusu sonucu sedanter bir yaşam tarzı sürer. Bunun sonucunda fiziksel aktivite düzeyleri düşer ve egzersiz kapasiteleri azalır. Azalan fiziksel aktivite ve sedanter yaşam tarzı, hastaların kas-iskelet sistemleri üzerinde de olumsuz etkilere yol açar ve postüral bozukluklara neden olur.

Sonuç olarak hastalar, günlük yaşamlarında düşük fonksiyonel kapasitesiteye sahip ve ilaca bağımlı bireyler haline gelirler. Bu durum, hastalığın semptomlarının açığa çıkmasını veya ilerlemesini hızlandırır; depresyon ve anksiyeteye yol açarak yaşam kalitelerini düşürür. Bir süre sonra da kısır bir döngüye yol açarak hastalığın tedavisini zorlaştırır (3). KOAH'ın tıbbi tedavisinde birçok yöntem uygulanmasına rağmen, ortaya çıkan bu kısır döngü nedeniyle tedavideki başarı bazen oldukça düşük olur.

Literatürde KOAH üzerine yapılan çalışmalarda kriter olarak alınan parametreler, KOAH'nın semptom ve bulguları (4), pulmoner fonksiyonlar (5), fiziksel aktivite düzeyi ve yaşam kalitesine yönelik $(6,7)$ parametreler olmuş ve çalışmaların çoğunda bunlar tek tek ele alınmıştır. Hastalıkla ilişkili bu parametreler, hastaların günlük yaşamı ve fonksiyonel düzeyleri ile birebir ilişkili parametreler olmalarına rağmen, bunların hepsini bir arada inceleyen çok az sayıda çalışma vardir.(8) 
Literatürde KOAH'lı hastaların hastalıkları veya uygulanan tıbbi tedavilere bağlı olarak ortaya çıkabilen sekonder problemlerine yönelik çalışmalar da yok denecek kadar azdır. Yeni yapılan bir çalışmada, KOAH'lı hastalarda kemik mineral yoğunluğu incelenerek osteoporoz ve osteopeninin varlığı ortaya konulmuştur (9). Ancak KOAH'lı hastalarda pulmoner kapasite, fiziksel aktivite düzeyi, yaşam kalitesi gibi parametrelerin yanısıra, kemik mineral yoğunluğunu ve kas-iskelet sistem problemlerini bir bütün olarak değerlendiren bir çalışmaya henüz rastlanmamıştır.

KOAH'lı hastalarda, hastalığa bağlı olarak görülen azalmış pulmoner fonksiyonlar, düşük efor kapasitesi ve düşük fiziksel aktivite düzeyi gibi primer problemlerin yanı sıra, kas zayıflıkları, kas kısalıkları veya uzun süreli kortikosteroid kullanımına bağlı olarak ortaya çıkabilecek osteoporoz, kifoz veya diğer postural deformiteler gibi kas-iskelet sistemine ait sekonder problemlerin de ortaya konulması oldukça önemlidir. Bu problemlerin varlığı, hem hastalığın prognozunu, hem de tedaviye olan yanıtlarını negatif yönde etkileyerek hastaların yaşam kalitesini daha da düşürür ve kısır bir döngü ile tıbbi bakıma ve rehabilitasyona olan gereksinimi artırır.

Günümüzde tüm toplumlarda giderek artan KOAH hastaları ve bu hastaların yaşamları sırasında ortaya çıkan sekonder problemler, tıbbi bakım veya rehabilitasyona olan gereksinimi arttırdığı gibi sağlık harcamalarını da arttıracaktır (10). KOAH'lı hastaların sadece pulmoner fonksiyonlar, fiziksel aktivite düzeyi veya yaşam kalitesi gibi belli parametreler yönünden değerlendirilmesi yerine, ortaya çıkabilecek osteoporoz gibi sekonder kas-iskelet sistem problemleri ile birlikte değerlendirilmesi, hastalığın hem tıbbi tedavisine hem de rehabilitasyonuna farklı bir bakış açısı kazandıracaktır. Rehabilitasyonunda da sadece interdisipliner olarak değil, transdisipliner olarak gögüs fizyoterapisi ve ortopedik rehabilitasyon alanında özelleşen fizyoterapistlerin yakın iletişiminin veya ortak çalışmasının önemini de ortaya koyacaktır. Ayrıca bu problemler oluşmadan önce, problemlerin önlenmesine yönelik olarak yapılacak çalışmalar için de bir temel teşkil edecek ve hastaların bakım gereksinimini ve sağlık harcamalarını azaltacaktır.

KOAH'lı hastaları, komorbiditeleri, semptomları ve sekonder problemleri ile birlikte değerlendiren; fiziksel durumlarını, ağrılarını, pulmoner fonksiyonlarını ve 
psikososyal faktörlerini birlikte inceleyen kapsaml, sistematik bir test yöntemine ihtiyaç duyulmaktadır. Çalışmamızda da literatürdeki bu boşluğu doldurmak, $\mathrm{Bu}$ çalışmada KOAH'lı hastalarda çok yönlü bir değerlendirme yaparak hastaları bir bütün olarak ele almak ve osteoporoz dahil, bu hastalığa veya tedavisine sekonder olarak ortaya çıkabilecek kas-iskelet sistem problemlerinin varlığını incelemek amaçlanmıştır.

Çalışmamızda ortaya koyduğumuz hipotezler:

Hipotez-1: KOAH'lı hastalarda solunum fonksiyonları ve egzersiz kapasitesi KOAH olmayan bireylere göre azalmıştır.

Hipotez-2: KOAH'lı hastalarda yaşam kalitesi ve psikososyal durum KOAH olmayan bireylere göre farklıdır.

Hipotez-3: KOAH'lı hastalarda kemik mineral yoğunluğu, ağrı ve kas kuvveti KOAH olmayan bireylere göre farklıdır. 


\section{GENEL BİLGILER}

Kronik Obstrüktif Akciğer Hastaliği (KOAH); zararl1 gaz ve partiküllere karş1 havayolları ve akciğerin artmış kronik inflamatuvar yanıtı ile ilişkili, genellikle ilerleyici özellikteki kalıcı hava akımı kısıtlanması ile karakterize, yaygın, sıklıkla önlenebilir ve tedavi edilebilir bir hastalıktır. KOAH gelişmiş ve gelişmekte olan ülkelerde görülen en önemli kronik hastalıklardan biridir. Akciğerler dışında yol açtığı akciğer dışı sistemik etkiler de hastalığın şiddetine katkıda bulunmaktadır. Alevlenmeler ve komorbiditeler hastalığın şiddetine katkıda bulunmaktadır (11).

Son yüzyılda gelişen küreselleşme, hızlı ve plansız şehirleşme, nüfusun giderek yaşlanması, batılı yaşam tarzının yaygınlaşması ve insan sağlığını olumsuz yönde etkileyen yeni risk faktörlerinin (tütün kullanımı, iç-dış ortam hava kirleticiler, allerjenler, mesleki maruziyet, sağlısız beslenme, obezite ve fiziksel aktivite yetersizliği) ortaya çıkması hastalığın oluşma hızını artırmıştır. Gelişmekte olan ülkelerde insidans ve prevalansı daha yüksek olan $\mathrm{KOAH}$, bu ülkeler açısından ciddi sosyoekonomik yük oluşturmaktadır. Hastalığı önleyici ve hastalıktan koruyucu çabalara rağmen, KOAH'ın mortalitesinin ve görülme sıklığının önümüzdeki yıllarda hızla artacağı öngörülmektedir $(12,13)$.

Hastalık genellikle yavaş ilerleme gösterir ve bu nedenle KOAH'lı hastalar erken dönemdeki semptomlarını genellikle sigara içiminin veya yaşlanmanın doğal sonucu olarak görürler. Ancak semptomları, özellikle nefes darlığ1 ve öksürüğün çok belirgin hale geldiği ileri evrelerde hastaneye başvururlar. $\mathrm{KOAH}$, tüm dünyada önemli bir halk sağlığı sorunu olmasına karşın, halen kamuoyu ve hekimler tarafından yeterince bilinmeyen, yeterince teşhis edilmeyen ve genellikle de eksik tedavi edilen bir hastalıktır $(14,15)$.

\section{Kronik Obstrüktif Akciğer Hastalığı (KOAH) Epidemiyolojisi}

KOAH, tüm dünyada önde gelen mortalite ve morbidite nedenidir. Neden olduğu büyük ekonomik ve sosyal yük giderek artmaktadır. Hastalığın mortalite, morbidite ve prevalansı ülkeler arasında ve hatta aynı ülke içindeki farklı topluluklarda farklılıklar göstermektedir. KOAH'ın prevalansı ve hastalık yükünün risk faktörleriyle (tütün dumanı, iç ortam hava kirliliği ve mesleki maruziyet) sürekli 
karşılaşma ve dünya nüfusunun giderek yaşlanmasına paralel olarak önümüzdeki yıllarda artmaya devam edeceği düşünülmektedir.

Sağlık Bakanlığı'nca 2000 yılında yapılan ve Türkiye'de ölüm nedenlerini tahmin etmeyi hedefleyen Ulusal Hastalık Yükü Çalışmasında, KOAH'ın üçüncü ölüm nedeni olduğu bildirilmiştir. Adana ilinde 2004 Ocak ayı içinde yapılan bir prevalans çalışmasında, bu ildeki 40 yaş üstü yetişkinlerde sabit oran ölçütü kullanıldığında KOAH prevalansının \%19,1 olduğu (erkeklerde \%28,5 kadınlarda \%10,3) saptanmıştır (16). Arslan ve ark. 2013 yılında Kocaeli bölgesinde yaptığı çalışmada ise Evre I KOAH prevalansı \%13,3 Evre II KOAH prevalansı ise \%7,1 olarak bulunmuştur (17).

\section{KOAH Prevalansı}

Günümüzde $\operatorname{artan} \mathrm{KOAH}$ farkındalığı ve yaşlanan nüfusun etkisi ile bu hastalığın prevalansının çok daha yüksek olduğu düşünülmektedir.1996'da, 16 milyon KOAH hastasının bulunduğu bildirildiği halde, gerçek sayının 22 milyon civarında olduğu tahmin edilmektedir; çünkü KOAH prevalansında en önemli sorun yetersiz tanıdır. KOAH hastalarının sadece dörtte birinin bir sağlık kuruluşunda tanı aldığı gösterilmiştir. Amerika Birleşik Devletleri (ABD)'de yapılan bir çalışmada, hava akımı obstrüksiyonu saptanan yetişkinlerin \%70'inin, Latin Amerikada yapılan bir çalışmada ise \%88,7'sinin KOAH tanısı almadığı görülmüştür (18). Tanı almamış bu hasta grubu genellikle hafif-orta şiddette KOAH'a sahiptirler. İspanya'da yapılan bir çalışmada KOAH prevalansı \%10 bulunurken, bu hastaların sadece \%27'sinin daha önce KOAH tanısı aldıkları görülmüştür (19). Norveç’te yeni yapılmış bir epidemiyolojik çalışmada, \%70’i solunum semptomlara sahip olmalarına rağmen, KOAH'lı erkek hastaların sadece \%20'sine, kadın hastaların ise ancak \%30’una bir doktor tarafından KOAH tanısının konduğu gözlenmiştir.

KOAH prevalansından bahsedilirken yaş ilerledikçe prevalansın da belirgin şekilde arttığı unutulmamalıdır. 40-50 yaş grubunda prevalans \%5'in altında iken 70 yaş üstü hastalarda \%30'un üstüne çıkmaktadır. Her ne kadar KOAH 40 yaşın altında nadiren görülse de, tüm KOAH'lı hastaların yaklaşık \%10'unun 40 yaş altı kişilerde olduğu akılda tutulması gerekir (20). Erken yaşta sigara içmeye başlayanlar, yoğun sigara içicileri ve başta alfa-1 antitripsin eksikliği olan kişiler olmak üzere kuvvetli 
genetik yatkınlığı olan kişilerde KOAH çok daha erken dönemde ortaya çıkmaktadır $(21,22)$.

\section{Mortalite ve morbidite}

ABD'de yaşa uyarlanmış KOAH mortalite hızları 1970-2002 arasında ikiye katlanırken, son çalışmalar bazı gelişmiş ülkelerde (Avustralya, İspanya) KOAH mortalite hızlarında azalma başladığını göstermektedir. $\mathrm{Bu}$ durumun, sigara içme prevalansında ve hava kirliliğindeki azalma ile ilişkili olduğu belirtilmiştir. "Küresel Hastalık Yükü Çalışması” verilerine göre (2010), KOAH yılda 2,9 milyon ölüme neden olmaktadır. Günümüzde dünyada 3. ölüm nedeni haline gelen $\mathrm{KOAH}$, tüm ölümlerin de $\% 5,5$ 'inden sorumludur $(23,24)$. Ülkelerde $\mathrm{KOAH}$ hastalarının mortalite ve morbidite verileri genellikle sağlıklı bir şekilde elde edilememektedir ve elde edilenlen verilerin güvenilirliği de tartışmalıdır. Bunun temel nedeni de, ülkelerin sağlık sistemlerinde ve tanı-tedavi pratiğindeki farklılıklar ve komorbiditelerdir.

Son y1llarda Dünya Sağlık Örgütü (DSÖ) tarafından hastalık yükünü değerlendirmede "Years of Healty Life Lost Due to Disability (YLD)" ve "Disability Adjusted Life Years (DALY)" ölçütleri kullanılmaktadır. Gerek sakatlık nedeniyle kaybedilen yıllar olarak tanımlanan YLD, gerekse erken ölümler ve sakatlık nedeniyle kaybedilen yılların toplamı olarak tanımlanan DALY açısından KOAH, önemli bir morbidite nedenidir ve önümüzdeki yıllarda hastalığın yaygınlaşmasına paralel olarak KOAH'a ikincil YLD ve DALY'nin daha çok artması beklenmektedir $(25,26)$.

\section{Mali Yük}

KOAH'ta doğrudan (tanı ve tedavi harcamaları) ve dolaylı (sakatlığın ekonomik sonuçları, kaybedilen iş gücü, erken ölüm, hastalık nedeni ile yapılan harcamalar vb.) maliyet oldukça yüksek düzeylerdedir (27). KOAH alevlenmeleri doğrudan maliyetin yaklaşık \%60'ına neden olmaktadır. KOAH'ın neden olduğu küresel ekonomik maliyet günümüzde 2,1 trilyon Amerikan Doları (USD \$) düzeyindedir ve bu maliyetin 2030 yılına kadar 4,8 trilyon USD \$'a yükselmesi beklenmektedir (14). Bu konu ile ilgili Türkiye'de Hacievliyagil ve ark. 2006 
yılında yaptıkları bir çalışmada ise KOAH'lıların hastane yatış maliyetlerini araştırmış ve hasta başına ortalama 1336 TL olarak saptamışlardır (26).

\subsection{Kronik Obstrüktif Akciğer Hastalığı (KOAH) Risk Faktörleri}

$\mathrm{KOAH}$, genetik duyarlılık ve çevresel uyaranlara maruz kalma arasında karşılıklı etkileşim sonucu ortaya çıkan bir hastalıktır. Aktif sigara içimi, hastalığın en önemli nedenidir (28). Ancak, mesleki koşullar ve hava kirliliği de önemli risk faktörleridir. Yoksulluk, yetersiz beslenme ve fiziksel inaktivite gibi diğer risk faktörleri, hastalığın gelişimi ve prognozunda daha dolaylı etkilere sahiptir.

Genetik faktörler: KOAH'ta iyi tanımlanmış genetik risk faktörü olan serin proteaz alfa-1antitripsin (AAT) eksikliğidir (21). Sigara içiminin eşlik etmesi durumunda, AAT eksikliği panlobüler amfizem gelişme riskini belirgin şekilde artırır (48). KOAH gibi karmaşık hastalıklar genellikle genetik altyapı ve çevre etkileşimi sonucu ortaya çıkar. Bu nedenle hastalık gelişimi ile ilgili olabilecek birçok aday genler yaygın şekilde araştırılmıştır. Tümör Nekroz Faktörü (TNF) alfa, Matriks Metalloproteinaz (MMP) 9, alfa 1-antikimotripsin (SERPINA-3), GlutatyonStransferaz (GST), vitamin D bağlayan protein, mikrozomal epoxide hidrolaz (mEH) en çok araştırılan genlerdir (29). Bununla birlikte KOAH çok yönlü bir hastalık olup, genetik faktörlerin yanında epigenetik faktörlerden de etkilenir (30).

Sigara kullanımı: Sigara, KOAH için çevresel risk faktörleri içinde başta gelen sebeplerden biri sayılsa da, sigara içenlerin sadece \%15'inde bu hastalığın gelişmesi, hastalığın oluşumunda başka etkenlerin olduğunu düşündürür. Sigara içimi ile pulmoner fonksiyonlar arasında bir doz-cevap ilişkisi saptanmış olsa da, oluşan hava akımı kısıtlılığının bireyler arasında farklılık göstermesi diğer risk faktörlerinin de varlığını destekler. Sigara içmeyenlerin sigara dumanı etkisinde kalmasını ifade eden "pasif sigara içiciliği”"nin etkileri özellikle prenatal ve/veya postnatal dönemde görülür. İntrauterin dönemde annenin sigara kullanması akciğer gelişiminde gerileme ve düşük doğum ağırlığına yol açarken, çocukluk döneminde duman maruziyeti ise akciğer gelişminin gerilemesine yol açar. Yapılan çalışmalarda, sigara kullanmayan kişilerin çocukluk ve erişkin yaş döneminde çevresel tütün dumanına maruz kalma süresi ve yoğunluğu ile $\mathrm{KOAH}$ gelişimi arasında anlamlı ilişki saptanmıştır (31). 
Mesleki toz, buhar ve duman maruziyeti: Mesleki toz ve kimyasallara (buhar, irritan ve duman) yeterli yoğunluk ve süre boyunca maruz kalmak da KOAH gelişimine neden olabilir. İşyerlerinde organik ve inorganik tozlara, kimyasal ajanlara ve dumanlara maruziyet, KOAH gelişimi için önemli bir risk faktörüdür; sigaradan bağımsız olarak KOAH gelişimine neden olabilir ve sigara içen kişilerde bu riski daha da artırır. Gaz ve partiküllerin yoğunluğu ve miktarı ve maruz kalma süresi, fonksiyonel etkilenme ile paralellik gösterir. KOAH gelisme riski yüksek olan meslekler arasında maden işçiliği (silika, kadmiyum ve kömür gibi), metal işçiliği, ulaşım sektörü ve odun/kağıt üretiminde çalışma, çimento, tahıl ve tekstil işçiliği ön planda yer alır $(32,33)$.

Hava kirliliği: Sosyo-ekonomik düzeyi yüksek ülkelerde hava kiırliliği \% 1 oranında KOAH'a sebep olurken Dünya Sağlık Örgütü'ne göre sosyo-ekonomik düzeyi düşük ülkelerde bu oran \% 2 olarak görülmektedir. KOAH progresyonunda etkili olan hava kirliliği aynı zamanda alt solunum yolu enfeksiyonları ve kardiyopulmoner olaylarla da ilişkilidir (34).

Yaş ve cinsiyet: Yaş, KOAH için önemli bir risk faktörüdür. Fakat, yaşın yaşam boyu toplam maruziyeti mi yansıttığı, yoksa bizzat yaşlanmanın mı hastalık gelişimine katkıda bulunduğu çok iyi bilinmemektedir. Cinsiyetin KOAH gelişimine olan etkisi tartışmalı olup, gelir düzeyi düşük ülkelerde mesleki maruziyete ve sigara kullanımına bağlı erkeklerde daha yüksek oranda görülürken,gelir düzeyi yüksek ülkelerde bu oran kadın ve erkeklerde neredeyse eşitlenmektedir (35).

Solunum sistemi enfeksiyonları: Solunum sistemi enfeksiyonlarının KOAH etyolojisi, patogenezi ve KOAH'ın doğal seyrinde etkileri olduğu bilinir. Ayrıca çocuklukta geçirilen enfeksiyonların (RSV, Adenovirüs gibi) yaşamın sonraki yıllarında solunum semptomlarında artış ve akciğer fonksiyonlarında azalma ile ilişkili olduğu ve her yeni alt solunum yolu enfeksiyonunun KOAH'da solunum fonksiyonlarındaki azalmayı hızlandırdığı bilinmektedir (36).

Sosyoekonomik durum: Düşük sosyoekonomik düzeyi olan bölgelerde beslenme, mesleki faktörler, iç ve dış ortam hava kirliliği gibi KOAH'ın diğer risk faktörleri bir arada olduğu için sosyoekonomik durumun KOAH'la doğrudan ilişkisini araştıran çalışma sayısı azdır. Yapılan çalışmalarda toplam gelirle ölçülen düşük sosyoekonomik durumun KOAH için bir risk faktörü olduğu ve bu gruptaki 
insanların akciğer fonksiyonlarının düşük olmaya meyilli olduğu gösterilmiştir (37, $38)$.

Beslenme: Diyetle alınan antioksidan özellikteki vitaminlerin (Vitamin A, C ve E) ve doymamış yağ asitlerinin, magnezyumun KOAH'a karşı koruyucu etkilerinin olduğu ileri sürülmustur. Buna karsılık,fazla tuzlu diyetin $\mathrm{KOAH}$ gelişimi için olası bir risk faktörü olduğu düşünülmektedir $(39,40)$. Malnutrisyon ve kilo kaybı solunum kas gücü ve kas kütlesini azaltarak, egzersiz kapasitesinde azalmaya ve yüksek morbiditeye neden olur. Vücut kitle indeksi (VKİ) düşük olan erkeklerde KOAH gelişme riskinin yüksek olduğunu bildiren çok sayıda çalışma mevcuttur (41).

\subsection{Kronik Obstrüktif Akciğer Hastalığının Patoloji, Patogenez ve Patofizyolojisi}

KOAH'ta özgü patolojik değişikler, proksimal ve periferal havayollarında , akciğer parankimi ve pulmoner vasküler yapılarda gözlenir. Bu patolojik değişiklikler, akciğerin farklı bölümlerinde yer alan sayıları artmış özel inflamatuvar hücre tiplerini içeren kronik infamasyon ve tekrarlayan zedelenme ve tamir süreçleri sonucunda gelişen yapısal değişikliklerdir. Genel olarak hastalığın şiddetinin artması ve sigara dumanına maruziyetin sürdürülmesi ile havayollarındaki inflamatuar ve yapısal değişiklikler değişim gösterir. KOAH’ta inflamasyon ; akciğerlerin başta sigara dumanı olmak üzere çeşitli zararlı partikül ve gazlara maruz kalması sonucu ortaya çıkar. İnhalasyon yoluyla alınan zararlı gaz ve partiküller, hastaların akciğerlerinde normalden daha abartılı bir inflamatuvar yanıta neden olur. $\mathrm{Bu}$ nedenle bu hastaların akciğer parankiminde ve pulmoner vasküler yapısında makrofajlar, nötrofiller, B ve T lenfositler gibi çeşitli inflamatuvar hücreler görülür. Kronik inflamasyon, küçük havayollarında yapısal değişim ve daralma ile sonuçlanır. Aynı zamanda parankimal doku harabiyetine (amfizem) ve normal doku tamir ve savunma mekanizmalarında bozulmaya (küçük hava yollarında fibrozis) yol açar. Sonuc olarak, akciğerlerin parankiminde, bronşioller ve alveollerde harabiyete yol açar; bu da alveolar bağların kaybına neden olur. Bu inflamasyon ile ilgili patolojik değişikliklerin her ikisi de, ekspirasyon sırasında hava yolunun açık kalma yeteneğini 
azaltır; hiperinflasyona veya hava hapsine ve ilerleyici hava akımı kısıtlamasına yol açar $(4,42,43)$.

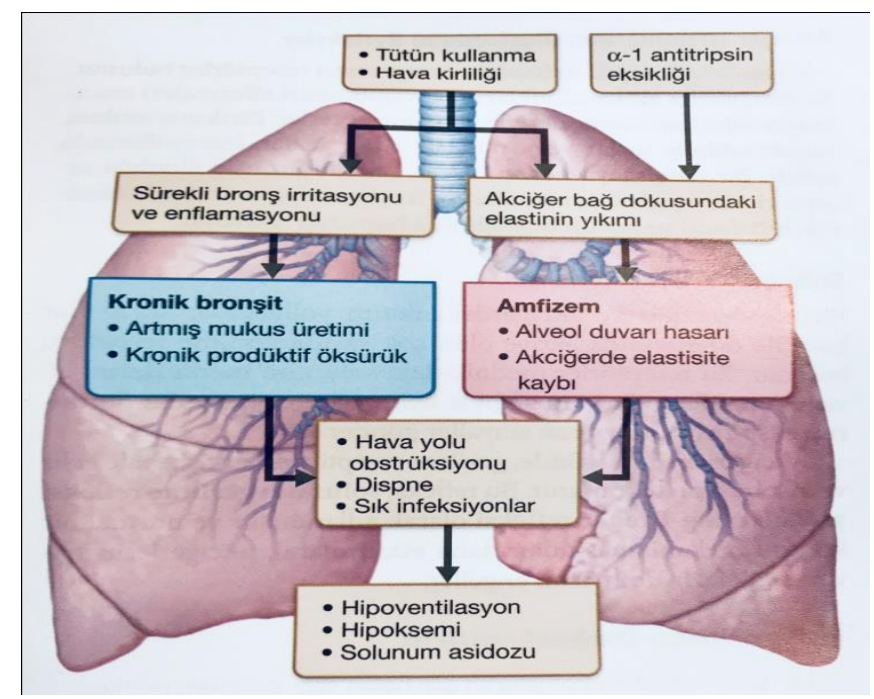

Şekil 2.1. KOAH'ın patogenezi (Marieb, E., Hoehn, K. (2017) Anatomy and Physiology (5.bs) (İ. Tatar). İstanbul: Nobel Yayınevi. (2017) s: 730.)

KOAH' ta gelişen anormal yanıtın patogenezde temel rol oynayan patoloji olduğu düşünülmektedir. KOAH'lı hastalarda, solunum yolunun sigara gibi irritan maddelere verdiği inflamatuar cevabın mekanizması henüz anlaşılmamıştır.Çalışmalar sigara içmeyi bırakmış KOAH hastalarında akciğer inflamasyonunun devam ettiğini kanıtlamıştır. İnflamasyon birincil olarak akciğer parankimi ve periferal havayollarında olsa da, sigara içmeyen ve ya içen ancak KOAH olmayan bireylerdeki bronş biyopsi örnekleri, stabil hafif-orta şiddetli KOAH'lıların bronş mukozasında inflamatuar hücre infiltrasyonunun arttığını kanıtlamıştır $(44,45,46)$.

KOAH'a özgü patofizyolojik değişikliklere genel olarak bakıldığında; aşırı mukus sekresyonu, siliyer disfonksiyon, hava akım kısitlanması, pulmoner hiperinflasyon, gaz alışverişinde bozulma, pulmoner hipertansiyon ve kor pulmonale ön plana çıkar. Hava yollarındaki inflamatuvar ve yapısal değişiklikler hastalık ilerledikçe artar ve sigara içiminin bırakılmasına rağmen devam eder (47). 


\subsection{Kronik Obstrüktif Akciğer Hastalığının Alt Tipleri}

Kronik Bronșit: Ardarda iki yılda, en az üç ay süre ile devam eden öksürük ve balgam varlığı kronik bronşitin göstermektedir. Kronik bronşitte öksürük ve balgam üretimi, zararlı gazların inhalasyonu sonucu gelişen immün cevaptan dolayı olmaktadır. Kronik bronşitte santral havayolları epitelinde ve mukus üreten bezlerde inflamasyon varlığı mevcuttur. Havayollarındaki inflamasyon, mukus üretiminde artış, mukosiliyer temizlenmede azalma ve hava boşluğu epitel bariyerinin geçirgenliğinde artış ile doğrudan ilişkilidir.

Sigara kullanımı, kronik bronşit için en önemli risk faktörleri arasındadır. Nikotine maruz kalma sonucunda oluşan inflamatuar cevap mukus sekresyonuna, kapiller sistem ve havayollarının yapısında bozulmaya sebep olmaktadır. Prognoz, yaş, sigara kullanımı ve havayolu obstrüksiyonunun derecesine göre bu değer değişim göstermektedir. Sigara içicilerinde 10 yıllık mortalite oranı \% 60 iken, bu oran sigara kullanmayanlarda \% 15 olarak görülmektedir. Bir günün en az yarısını yatakta geçirenler, mobil olanlara göre mortalite açısından dört kat daha riskli hasta grubudur $(48,49)$.

Amfizem: Amfizem, havayollarının yıkımı nedeniyle distal hava yollarının anormal ve geri dönüşümsüz genişlemesi olarak bilinmektedir. Amfizematöz akciğer yıkımı, elastik geri çekilim kuvvetini azaltarak, maksimal ekspiratuar hava akış hızını azaltmaktadır. Amfizemin daha çok sigara kullanımı ile ilgili olan sentrilobüler formu, respiratuar bronşiollerin dilatasyonu sonucu oluşmaktadır. Antitripsin eksikliği ile ilgili olan panlobüler formu ise, tüm asinüsün genişlemesi veya yıkımı ile sonuçlanmaktadır. Amfizemin şiddeti ile sigara kullanma süresi arasında da ilişki mevcuttur. Ağır sigara içicilerinin \% 40’’nda, amfizem kaynaklı akciğer yıkımı görülmektedir. Sigara kullanımını sürdüren amfizemli hastalarla karşılaştıııldığında, sigarayı bırakanlarda $\mathrm{FEV}_{1}$ 'deki düşme daha yavaş görülmektedir. $\mathrm{Bu}$ nedenle sigarayı bıraktırma, amfizemli hastalarda tedavinin önemli bir parçası olarak bilinmektedir.

Amfizemli hastaların en önemli şikayeti, efor sırasında hissedilen dispne hissidir. Göğüs duvarının anterior-posterior çapında genişleme saptanmaktadır. Yardımcı solunum kasları genellikle hipertrofiye uğramıştır. Enfeksiyona bağlı olarak kronik öksürük ve balgam üretimi görülebilir (48). 
Küçük Havayolu Hastalığı: KOAH’ta havayolu obstrüksiyonunun büyük bir bölümü, çapı 2 mm'den küçük iletici havayollarında oluşmaktadır. Hastalığın şiddeti ile havayolu lümenindeki inflamatuar fibröz sıvı (eksuda) kaynaklı tıkanıklık arasında ilişki görülmektedir. İnflamasyon ve peribronşiyal fibrözis, küçük havayollarında obstrüksiyona katkıda bulunmaktadır (49).

\subsection{Kronik Obstrüktif Akciğer Hastalığının Semptomları ve Bulguları:}

Dispne (nefes darlığı) KOAH'ta başlıca semptomdur ve kronik progresif özellik gösterir. Ayrıca, öksürük ve balgam çıkarma da en önemli semptomlar arasında yer alır. KOAH ilerledikçe artmış öksürük, artmış nefes darlığı, pürülan balgam ve hırıltı (wheezing) varlığı gibi bulgular da ortaya çıkar.

KOAH'ta semptomlar günden güne hatta gün içinde bile değişkenlik gösterebilir ve gün içinde en sık sabah saatlerinde daha yoğun hissedilir.

KOAH'lı hastalarda nefes alma sırasındaki hava akımı hasarlanmış alveol duvarları ve kalınlaşmış bronşioller nedeni ile bozulmuştur. Bu durum KOAH'lı hastalarda düşük enerjili aktiviteler ve istirahat halinde bile sağlıklı erişkinlerin yüksek enerjili aktivitelerinde olduğu gibi solunum güçlüğü yaşamasına neden olur. KOAH'lı hastalar daha fazla nefes almasına rağmen, akciğerlere olan hava akımı oldukça azdır. $\mathrm{Bu}$ durum, ekspirumda alveollerin boşalmasındaki bozulma (ekshalasyon yetersizliği) nedeni ile olur ve solunum sayısındaki artış ile daha fazla hava hapsine yol açar (38). Bu nedenle bu hastalarda kronik ve ilerleyici nefes darlığı, hastayı doktora başvurmaya yönlendiren en önemli semptomdur.

Dispne hastalar tarafından "nefes almada zorluk", "ağırlık", "hava açlığı" veya "zorlukla solumak" olarak tanımlanır ve bu nefes güçlügü tipik olarak kalıcı ve ilerleyicidir. Dispne genellikle yorucu egzersiz sırasında, merdiven veya yokuş çıkarken veya düz yüzeylerde hızlı yürürken fark edilir. Geceleri ortaya çıkan dispneye paraksismal nokturnal dispne (PND) denir. Hastalarda dispne nedeniyle uzun yürüyüşler kısıtlanabilir ve hastaların yaşıtlarına göre yürüyüş hızı düşebilir. Hastalık ilerledikçe, giyinme, bakım ve banyo gibi iki taraflı baş üstü kol aktivitelerini içeren fonksiyonel aktiviteler veya efor gerektiren bazı aktivitelerile dispne tetiklenir veya dispnenin şiddeti artar. Dispne, hastanın yaşı, sahip olduğu diğer hastalıklar ve hastalığg hakkındaki düşüncelerinden etkilenebilir (9). 
Antoniu'ya göre KOAH'lı hastalarda nefes darlığ 1 sıklıkla dinamik hiperinflasyonun sonucudur (49). $\mathrm{Bu}$ durum akciğerlerin ekspirasyon sirasında tam olarak boşalamaması ve artmış reziduel volüm ile açıklanır. Dinamik hiperinflasyonla ilişkili diğer faktörler ise; nöro-kimyasal disfonksiyon, hipoksemi, hiperkapni veya ventilasyon perfüzyon dengesizliğinin olduğu klinik durumlardır $(50,51)$.

Birçok hasta nefes darlığı veya dispneden kaçınmak için günlük hareketlerini kısıtlar; bu da hastaların daha sedanter bir hayat sürmelerine neden olur ve egzersiz intoleransı gelişir. KOAH'lı hastalarda dispne ve egzersiz intoleransı, birçok faktörden etkilenir. Ekspiratuvar havayolu obstrüksiyonu önemli bir nedendir (42). Ayrıca inspiratuvar kas disfonksiyonu, gaz değişim anormallikleri ve kardiyak disfonksiyon diğer önemli nedenlerdendir (52, 53). Egzersiz intoleransı dinamik hiperinflasyon konsepti ile açıklanabilir (54). Toraksın hareketleri hiperinflasyona bağlı olarak kısıtlanır ve egzersiz sırasında tidal volümde yeterli artış sağlanamaz. Hiperinflasyon ayrıca inspiratuvar kasların yeterli gücü oluşturamamasına ve güçsüzleşmesine yol açar (55). Sonuç olarak, KOAH'lı birçok birey günlük aktivite seviyesini azaltır ve sosyal aktivitelerini minimuma çeker.

Tablo 2.1. KOAH'lı hastalardaki kas güçsüzlüğünün nedenleri

\section{KOAH’lı hastalardaki kas güçsüzlüğünün nedenleri.}

\begin{tabular}{|l|l|}
\hline Kondisyon eksikliği & Sistemik kortikosteroidler \\
\hline Sistemik inflamasyon & Hipoksemi \\
\hline Oksidatif stres & Hiperkapni \\
\hline Beslenme dengesizliği & Elektrolit bozuklukları \\
\hline Azalmış anabolik aktivite & Kalp yetmezliği \\
\hline
\end{tabular}

KOAH'lı bireylerde en sık karşılaşılan semptom öksürük olmasına rağmen, solunum güçlüğü çekmeye başladıklarında genellikle doktora başvururlar. Öksürük $\mathrm{KOAH}$ etyolojisinde yer alan zararlı gaz ve partiküllere havayollarının ilk cevabı öksürüktür. Başlangıçta aralıklarla ve non-prodüktif iken, daha sonra her gün olan bir yakınma haline gelebilir. Kronik kuru öksürük de olabilir. Hastanın doktora başvurduğu süreçte prodüktif nitelik kazanabilir. 
Balgam çıkarma, KOAH hastalarında hava akımı kısıtlanması ile birlikte balgam genelde yapışkan, çıkartılması zor, mukoid niteliktedir. Hava akım kısıtlanması olmaksızın birbirini izleyen iki yıl ve özellikle kış aylarında 3 ay ya da daha fazla süreyle balgam çıkarma ve öksürüğün varlığı klinik olarak "kronik bronşit" olarak tanımlanır. Balgam çıkarma yakınması KOAH'lı olgularda bronşektaziyi düşündürebilir. Balgamın pürülan özellikte olması, içindeki inflamatuvar mediatörlerin artışına bağlıdır ve bakteriyel enfeksiyonu gösterebilir. Balgam üretimi genellikle bir günde "kısıtlı" ya da "birkaç çorba kaşığı sümüksü, seyrek, sulu salgıdan daha az" şeklinde tanımlanır. İrin içeren pürülan salgıları, enfeksiyon atakları sırasında görülür.

Risk faktörlerine maruz kalan kişilerde kronik öksürük ve balgam çıkarma, hava akım kısıtlanması gelişiminden yıllar önce ortaya çıkabilir. Bu hastaların bir kısmında kronik yakınmalar varken, bazı hastalar ilk akut alevlenmeye bağlı yakınmalarla gelebilir. Kronik semptomları ve risk faktörlerine maruziyet öyküsü bulunan orta-ileri yaştaki yetişkinlerde spirometrik değerlendirmede yerleşik hava akımı obstrüksiyonu saptanması (post bronkodilatör $\mathrm{FEV}_{1} / \mathrm{FVC}<\% 70$ ) tanıyı doğrular. KOAH tanısını koymak içi GOLD tarafından tanımlanmış algoritmaya uygun yolun izlenmesi önerilir (1).

\subsection{Kronik Obstrüktif Akciğer Hastalığında Değerlendirme}

\subsubsection{Fizik Muayene}

Inspeksiyon: İnspeksiyon sırasında hastaların odaya girme, yürüme, oturma ve hafif aktiviteleri dahil, bazı aktivitelerdeki postürü ve solunum paterni incelenir. $\mathrm{Bu}$ aktiviteler sırasında solunum sıkıntısı yaşayıp yaşamadığı değerlendirilir. Solunum yetmezliği gelişen hastalardaki paradoksal solunum paterni, sırtüstü yatış pozisyonunda daha net gözlemlenir. Özellikle ileri dönem hastalarda solunumun derinliği azalırken, frekansı artar ve istirahatte bile 20 soluk/dk'nın üzerinde olur. Hasta dispnesi nedeni ile uzun cümleler kuramaz.

Alt lateral göğüs duvarının inspirasyonda içeri çekilmesi Hoover belirtisi olup ileri dönem KOAH hastalarında ayırıcı tanı olarak kabul edilir. Hiperinflasyon sebebi ile gögüs ön arka çapının artması sonucu fiçı gögüs görülebilir. Göğüs kafesinin ön arka hareketliliği azalmıştır. Bunların yanısıra, hipoksemik hastalarda santral 
siyanoz, ekspirasyonda büzük dudak solunumu ve yardımcı solunum kaslarının hiperaktivitesi, hiperkapni ve takipne de görülebilir. Kor pulmonale gelişen hastalarda periferik ödem ve juguler venöz dolgunluk gözlemlenebilir.

Palpasyon: Toraksın solunum ile genişlemesinde kısıtlanma tespit edilebilir. Hiperinflasyona bağlı karaciğer en alt kosta altında palpe edilebilir. Kalp tepe atımı güçleşebilir. Kor pulmonalede alt ekstremitedeki ödem palpe edildiğinde godet birakabilir.

Perküsyon: Perküsyonda diyafragma hareketinde azalma tespit edilebilir.

Oskültasyon: Dinleme ile solunum seslerinde azalma, ekspirasyon süresinde uzama tespit edilir. Hastaya zorlu ekspirasyon zamanı tayini yapılabilir. KOAH'l1 hastalarda spesifik olmasa da ronküsler duyulabilir. Atak dönemlerinde de inspiratuar raller işitilebilir.

\subsubsection{Spirometrik Değerlendirme}

Spirometrik değerlendirme ile solunum fonksiyonları ölçülür ve obstrüksiyonun şiddeti belirlenir.

\section{Solunum Fonksiyon Testleri}

KOAH'ın varlığına ve şiddetine karar vermek için iki zorunlu spirometri ölçümleri rutin olarak kullanılır:

1 Saniyedeki Zorlu Ekspiratuvar Volüm (Forced Expiratory Volume in one second $=\mathrm{FEV}_{1}$ )

Zorlu vital kapasite (Forced VitalCapasity=FVC)

Spirometrik ölçümler ile ayrıca $\mathrm{FEV}_{1} / \mathrm{FVC}$ oranı da hesaplanmalıdır. KOAH'ta görülen $\mathrm{FEV}_{1}$ 'deki azalma öncelikli olarak enflamasyondan kaynaklanır. Hesaplanan bir $\mathrm{FEV}_{1} / \mathrm{FVC}<0,7$ ile tahmin edilen $\mathrm{FEV}_{1}<\%$ 80'lik bir postbronkodilatatörün varlığı, tamamen geri döndürülemeyen bir hava akımı sınırlamasının varlığını doğrular. 
Tablo 2.2. KOAH'lı hastalarda havayolu limitasyonu şiddeti sınıflandırılmasıGOLD 2017 (1) raporundan alınmıştır.

\begin{tabular}{l|l|l|}
\hline FEV $/$ FVC $<\mathbf{0 . 7 0}$ olan hastalar \\
\hline GOLD 1 & Hafif & $\mathrm{FEV}_{1} \geq \% 80$ (Tahmin edilen) \\
\hline GOLD 2 & Orta & $\% 50 \leq \mathrm{FEV}_{1}<\% 80$ (Tahmin edilen) \\
\hline GOLD 3 & Ciddi & $\% 30 \leq \mathrm{FEV}_{1}<50$ (Tahmin edilen) \\
\hline GOLD 4 & Çok ciddi & $\mathrm{FEV}_{1}<\% 30$ (Tahmin edilen)
\end{tabular}

Spirometrik ölçümler yaş, boy, cins ve ırka göre belirlenen referans değerlerle karşılaştırılarak değerlendirilir $(56,57)$.

\section{Diffüzyon Kapasitesi}

Vücudun oksijen ihtiyacını karşılayıp karşılamadığı belirlenmek için diffüzyon kapasitesi ölçümü yapılır.

Test sırasında organizmaya zarar vermediği bilinen karbonmonoksit (CO) ve helium (HE) gazı kullanılarak akciğer hacimleri ölçülür; böylece solunum havasının ne kadar alındığı ve bunun içindeki CO yardımıyla ne kadar gazın kana geçtiği saptanmış olur $(41,58)$.

\section{Arteryel kan gazı ölçümleri}

Arteryel kan gazlarının belirlenmesi bu hastalarda oldukça önemlidir. Arteryel oksijen düzeyindeki $\left(\mathrm{PaO}_{2}\right)$ azalma, KOAH'lı bireylerde hastalığın ilerlediğini gösterir. Arteryel karbondioksit $\left(\mathrm{PaCO}_{2}\right)$ düzeyi, hafif $\mathrm{KOAH}$ 'da normal olabilir veya güçlü anfizemli bileşene sahip hastalarda azalmış olabilir. İleri derecede bronşit bileşeni olan $\mathrm{KOAH}$ hastalarında hastalık ilerledikçe $\mathrm{PaCO}_{2}$ düzeyi de artar. Kan gazlarındaki anormallikler, genellikle hastalığın akut şiddetlenmeleri sırasında veya uyku veya egzersiz sırasında da görülür. Solunum yetmezliği riskini teşhis etmek için, hastanın $\mathrm{CO}_{2}$ seviyeleri ile ilgili bilgiler bilinmelidir. Koridor yürüyüşü veya bisiklet sürme gibi modifiye egzersiz testleri, oksijen takviyesi için bir ihtiyaç olup olmadığını belirlemek için kullanılabilir. 


\subsubsection{Fizyoterapi Değerlendirmesi}

\section{Solunum değerlendirilmesi}

Hastaların değerlendirmesinde öncelikle solunumun frekansı, tipi ve derinliği değerlendirilir. Ayrıca, torakal hareketliliği ölçmek için göğüs çevre ölçümü yapılır. Solunum frekansı, 1 dakikada alınan solunum sayısı olarak eğitime başlamadan önce, dinlenme durumunda ve eğitim sonrası dinlenme durumunda ölçülür.

\section{Dispne değerlendirilmesi}

Nokturnal dispne ve efor dispne ataklarının sayısı ve sıklığı, dispneyi arttıran ve azaltan nedenler değerlendirilir.

Ayrıca hastaların nefes darlığının günlük yaşam aktivitelerine olan etkisi Modifiye Medikal Araştırma Skalası ile (Modified Medical Research Council= mMRC), KOAH değerlendirme anketi CAT (COPD Assessement Test=CAT) ve BDI ( Başlangıç Dispne İndeksi) ile değerlendirilir $(4,19)$.

\section{Postür}

KOAH hastalarının çoğunda geri dönüşlü postür bozuklukları görülür. Genellikle omuzlarda elevasyon, torasik kifoz ve kompansatuvar lordoz görülür. Kifozda toraksın antero-posterior çapı artarken, lordozda azalır. Akciğerlerdeki hiperinflasyon sonucu fiçı göğüs görülür. Bu postür bozukluklarını değerlendirmek için detaylı bir postür analizi yapılır (59).

\section{A ̆grı}

Hastaların ağrı şiddetinin seviyesi egzersiz öncesi, egzersiz sonrası, gece, günlük aktiviteler sırasında değerlendirilir. Ağrının şiddeti ve özelliği, görsel ağrı skalası (VAS), Sözel Kategori Ölçeği, Numerik Ağrı Skalası, Burford Ağrı Termometresi, sayısal ölçekler, McGill Ağrı Anketi gibi değerlendirme yöntemleri kullanılarak değerlendirilebilir $(60,61)$. 


\section{Balgam ve öksürük}

Öksürme sıklığı, balgam olup olmadığı, balgamın miktarı, balgamın yapısı ve kokusu değerlendirilir.

\section{Kas kuvveti}

İleri düzeydeki KOAH'lı hastalarda sedanter yaşama bağlı olarak özellikle alt ekstremite kaslarında atrofi görülür. Kas statik veya izometrik kuvveti, tensinometre veya dinamometreler ile ölçülebileceği gibi manuel kas testi ile de değerlendirilebilir.

\section{Yorgunluk paterni}

Hastalar oksijen açlığı ve yorgunluk nedeni ile aktiviteyi çoğunlukla yarıda bırakmak zorunda kalırlar. Yorgunluk paterni Yorgunluk Ölçeği (Checklist Individual Strength=CIS) ile, yorgunluk düzeyi numerik olarak 1-10 arasında puanlanarak ölçülebilir. Yorgunluk aynı zamanda, nabızda artış, dudak ve tırnaklarda siyanoz, solunumda düzensizlik, hastanın postüründe bozulma ile de değerledirilir.

\section{Yaşam kalitesi, Anksiyete ve Depresyon}

Psikolojik olarak, KOAH'ın bireyin hayatı üzerindeki etkisi genellikle depresyon ve anksiyete duygularına yol açabilir. Yaşam kalitesi, SF36 (Medical Outcome Study), Nottingham Sağlı Profili (Nottingham Health Profile), İyilik Kalitesi Skalası (Quality of Well-Being Scale), Hastalık Etki Faktörü (Sickness Impact Profile) gibi anketlerin yanısıra hastalığa özgü yaşam kalitesi değerlendirme anketleri (Chronic Respiratory Questionnaire, Saint George Respiratory Questionnaire, Quality of Life Respiratory Illness Questionnaire) ile değerlendirilmeye alınabilir. Hastaların depresyon düzeyleri, Beck Depresyon Anketi ile, anksiyete düzeyleri ise Beck Anksiyete Ölçeği gibi ölçekler ile sorgulanabilir.

\section{Egzersiz kapasitesinin değerlendirilmesi}

KOAH tanılı hastalarda solunum sistemindeki patoloji sonucunda oksijen temini zorlaşmaktadır. Egzersiz sırasında vücudun ihtiyacı olan enerji ve oksijenin sağlanmasındaki sorunlar nedeni ile egzersiz intoleransı, periferik kaslarda 
güçsüzlük ve kardiyak fonksiyon bozuklukları ortaya çıkmaktadır (62). Bu nedenle egzsersiz kapasitesi ve fiziksel aktivite seviyesinin değerlendirilmesi önemlidir. Egzersiz kapasitesinin ölçümünde;

-Altı dakikalık yürüme testi (6 DYT),

-Artan hızda mekik yürüme testi,

-Kardiyopulmoner egzersiz testi

-Basamak testi gibi farklı yöntemler vardır.

6 Dakika Yürüme Testi (6DYT) genel olarak pulmoner, kardiyovasküler ve kas sistemlerinin entegre yanıtını değerlendirir. Altı dakika yürüme mesafesinin (6DYM) <350 metre olması ve yürüme mesafesinde >30 metrelik (m) azalma, mortalite riskinin arttığını gösterir (63). Artan hızda mekik yürüme testi için , minimal klinik anlamlılık değeri 47,5 metre olarak kabul edilir.

Kardiyopulmoner egzersiz testleri, egzersiz kapasitesindeki kazanımların elde edilip edilmediğini belirlemek için koşu bandı veya bisiklet ergometresi kullanılarak yapılır. Ayrıca kol ergometresi de kullanılabilir. Test sırasında hemodinamik yanıtlar (nabız, tansiyon, oksijen tüketimi, oksijen satürasyonu, elektrokardiyografik değişiklikler ve metabolik eşdeğer) sırasında ön test ve son test ölçümü olarak kullanılır.(64)

\section{Fiziksel aktivite düzeyinin değerlendirilmesi}

Günlük yaşamdaki fiziksel aktivitelerin ölçümü; fiziksel aktivite anketleri, pedometre, akselerometre gibi cihazlar kullanılarak yapılabilmektedir. 


\section{BİREYLER VE YÖNTEM}

Stabil durumdaki KOAH'lı hastalarda, solunum fonksiyonları, egzersiz kapasitesi, yaşam kalitesi, anksiyete, depresyon, ağrl, kas kuvveti ve kemik mineral yoğunluğunu incelemek, bu parametrelerden klinik ortamda uygulanması pratik ve anlamlı olanların belirlenmesi amacıyla yapılan bu çalışma, Haziran 2018- Ağustos 2018 tarihleri arasında Liv Hospital Göğüs Hastalıkları Kliniği ve Bahçeşehir Üniversitesi'nde yapılmıştır. Çalışmaya, aynı göğüs hastalıkları hekimi tarafından KOAH tanısı konulmuş 58 hasta ile başlanmıştır. 12 hasta, ilk değerlendirmeler yapılırken çalışmaya alınma kriterlerine uymadığı için çalışma dışı bırakılmışlardır. Geriye kalan 46 hastanın 6's1, değerlendirmelere katılmak istememeleri ve zaman problemleri olması sebebiyle çalışmayı bırakmışlar ve bu çalışma 40 hasta ile tamamlanmıştır. Kontrol grubu olarak benzer yaş ve cinsiyet dağılımlarına sahip 35 KOAH olmayan birey çalışmaya dahil edilmiştir.

Yaşları 40-70 yıl arasında değişmekte olan ve 19 kadın, 21 erkekten oluşan toplam $40 \mathrm{KOAH}$ 'lı hasta ile yaşları 49-69 yıl yaş aralığında değişen 14 kadın 21 erkek toplam $35 \mathrm{KOAH}$ olmayan birey kontrol grubu olarak programa dahil edilmiştir.

Katılımcılar ile yapılan ön görüş̧mede yapılan sağlık sorgulaması sonucunda uygun görülenler çalışmaya davet edilmiştir. Katılımcılar Helsinki Deklarasyonuna uygun bir şekilde çalışma prosedürleri içerisindeki risklerin kendilerine detaylı bir şekilde açıklanmasından sonra onam formlarını (EK 1) imzalayarak araştırmaya gönüllü olarak katılmışlardır. Katılımcılar çalışmanın herhangi bir aşamasında, istedikleri zaman çalışmadan ayrılabilecekleri konusunda ayrıca detaylı bir biçimde bilgilendirilmişlerdir. Aydınlatılııı̧ Onam Formunun bir kopyası da katılımcıya verilmiştir. Bu çalışma Üsküdar Üniversitesi "Girişimsel Olmayan Klinik Araştırmalar Etik Kurulu” tarafindan “61351342/2018/09” kabul edilmiştir (EK 2).

\subsection{Bireyler}

Çalışmaya, yaşları 40-70 yıl arasında değişen ve Özel LiV Hastanesi'nde aynı hekim tarafından GOLD önerilerine uygun şekilde aynı tetkikler yapılarak KOAH tanısı almış hastalar dahil edilmiştir. Çalışmamıza toplamda 40 KOAH hastası ve kontrol grubu olarak $35 \mathrm{KOAH}$ olmayan birey dahil edilmiş̧ir. 


\section{Çalışmaya Alınma Kriterleri:}

Çalışmaya, GOLD tanımına göre Evre I ve II olan (1) KOAH hastalığı tanısı konulmuş ve 40-70 yaş aralığında olan hastalar alınmıştır. Ayrıca hastaların,

- Son iki ay içinde atak geçirmemiş stabil hastalar olmasına,

- Benzer yaş aralığında olan (49-69 yaş) ve çalışmaya katılmayı kabul eden KOAH olmayan bireyler çalışmaya kontrol grubu olarak alınmıştır.

\section{Çalışma Dışı Bırakılma Kriterleri:}

- Evde oksijen tedavisi alan veya oksijen tedavisine sık gereksinimi olan $\mathrm{KOAH}$ hastalar1,

- Egzersizle indüklenen astımı olan hastalar,

- Kor pulmonale, pnömokonyoz veya interstisyel akciğer hastalığı olanlar,

- Primer pulmoner hipertansiyonu olan hastalar veya pulmoner emboli geçirmiş hastalar,

- Konjestif kalp yetersizliği ve ciddi koroner arter hastalığı olanlar veya koroner arter hastalığına bağlı by-pass cerrahisi geçirmiş olan hastalar,

- Parkinson, hemipleji, multiple skleroz gibi ciddi nörolojik hastalığı olanlar,

- Nöromusküler hastalığı olanlar,

- Demans, Alzheimer veya ileri düzey kognitif problem olan hastalar,

- Akciğer kanseri veya diğer malignite tanısı olan hastalar,

- Morbid obezitesi olan hastalar.

\subsection{Yöntem}

Çalışmaya dahil edilen $40 \mathrm{KOAH}$ hastası ve 35 kontrol grubuyla yapılan çalışmamızda, uyguladığımız tüm test ve parametrelerin herkeste aynı sırada yapılmasına özen gösterilmiştir. Hastalara bu çalışma için özel olarak hazırladığımız değerlendirme formu verilmiştir.

\subsection{Değerlendirme}

Çalışmada aşağıda yer alan değerlendirmeler yapılmıştır: 


\subsubsection{Demografik Özellikler}

Cinsiyet, yaş, boy, vücut ağırlığı ve vücut kütle indeksi (VKİ) kaydedilmiştir.

\subsubsection{Sosyodemografik Özellikler}

Hastaların eğitim durumları, medeni durumları, ekonomik durumları ve aktif çalışma hayatlarının olup olmadığı sorgulanmıştır.

\subsection{3. Özgeçmiş}

Başka kronik hastalıklarının olup olmadığı, herhangi bir cerrahi müdahale geçirip geçirmedikleri ve düzenli olarak kullandıkları ilaçlar sorgulanmıştır.

\subsubsection{Alışkanlıklar}

Alkol, sigara içip içmedikleri, sigara içenlerin sigara içme y1lı, bir günde kullandıkları sigara miktarı, sigarayı bırakanlar için bu zamana kadar geçen süre sorgulanmıştır.

\subsubsection{Ağrının Değerlendirilmesi}

Ağrının durumu Numerik Ağrı Skalası (0 en düşük 10 en yüksek ağrı seviyesi) kullanarak gece istirahatte ve aktivite ağrısı olarak değerlendirmeye alınmıştır.

\subsubsection{Postür Değerlendirilmesi}

Ayakta duruş pozisyonunda ön, yan ve arkadan sarkaç yardımı ile gravite hattından olan sapmalar değerlendirilmiş ve özellikle omurga ve üst gövdede olan postür bozuklukları gözlem yolu ile değerlendirilerek kaydedilmiştir (65).

\subsubsection{Solunum ve Kalp Hızı Değerlendirilmesi}

Solunum frekans1, 1 dakikada alınan solunum sayısı (atım/dakika) olarak dinlenme durumunda ölçülmüştür. Kalp hızı da hem dinlenme hem de efor sonrası değerlendirilmiştir. 


\subsubsection{KOAH Semptomlarının Değerlendirilmesi}

KOAH hastalığının ilk tanısının konma süresi, KOAH hastalığına bağlı olarak 1 yıl içinde geçirdiği atak sayısı, KOAH' tan dolayı yatağa bağımlı olup olmadığı, KOAH'a bağlı kilo kaybı ve gece terlemesi olup olmadığ değerlendirilmeye alınıp tıbbi bilgileri kaydedilmiştir.

-Medikal Araştırma Skalası (mMRC), İngiliz Medical Research Council Dispne Skalası'nın Amerikan Toraks Derneği (ATS) tarafından modifiye edilmiş şeklidir. Dispne ataklarını günlük yaşam aktiviteleri sırasında değerlendiren bir skaladır. Hastaların bulgularının evrelerini temsil eden 5 maddeden oluşur. Dispne, ataklarının şiddeti Evre 1'den Evre 5 doğru gittikçe kötüleşir. Hastaların dispne düzeylerini en iyi tanımlayan ifadeyi seçtiği 0-4 puanlık bir kategori skalasıdır. Hastalar, bu evrelerin temsil ettiği bulgulara bakarak kendi bulgularına uyan evreyi form üzerinde işaretler $(66,67)$ (Ek Tablo 1).

\section{-KOAH Değerlendirme Anketi (COPD- Assessment Test=CAT)}

$\mathrm{KOAH}$ hastalarında sağlık durumunu kısa sürede ortaya koyabilecek kısa ve basit bir testtir. KOAH'ın GYA üzerine olan etkilerini araştırmak üzere kullanılır. Sorular, hastaların nefes darlı̆̆ı, öksürük, balgam ve hırıltı gibi semptomlarını kapsamasının yanı sıra, yorgunluk ve uyku durumu gibi sistemik semptomlarını da kapsar. Anket toplam 8 sorudan oluşur ve her bir soru 0-5 puan arasında değerlendirilir. 0'dan 5 puana doğru gittikçe bulgular kötüleşir (68). Toplam skor 040 puan arasında değişmektedir. Türkçe geçerlik ve güvenirliği, 2012 yılında Yorgancıoğlu ve ark. tarafından yapılmıştır (69).

\section{-Saint George Solunum Anketi}

(Saint George Respiratory Questionnaire) (SGRQ)

Bu anket 3 ana bölümden oluşur:

- Semptomlar (sıklık ve şiddeti)

- Aktiviteler (efor dispnesine yol açan aktiviteler veya efor dipnesi nedeniyle k1sitlanan aktiviteler)

- Etki (hastalığın sosyal ve psikolojik etkileri) 
0-100 puan arasında derecelendiren toplam 76 sorudan oluşur ve yüksek puanlar semptomların daha şiddetli, düşük puanlar daha hafif olduğunu gösterir. Türkçe güvenirlik ve geçerliği Polatlı ve ark. tarafından 2013 yılında yapılmıştır $(70,71)$.

\subsubsection{Solunum Testlerinin Değerlendirilmesi}

\section{-Solunum fonksiyon testi (SFT)}

Solunum fonksiyonlarını ölçmek için kullanılır. Solunum fonksiyon testleri, spirometrik ölçüm yöntemi kullanılarak yapılır. Spirometrik testler, inspirasyon ve ekspirasyon sırasında oluşan hava akımını veya akciğer volüm değişiklerini, zamanın türevine göre ölçen bir fizyolojik testtir.Bu çalışmada solunum fonksiyon testleri spirometre ile, Cosmed Quark PFT ${ }^{\circledR}$ Pulmonary Function Test Machine, London, $U K$ cihazı ile uygulanmıştır. Solunum fonksiyon testlerine başlamadan önce sözel olarak anlatılmıştır. Solunum fonksiyon testi parametreleri yaş, boy, vücut ağırlığı ve cinsiyete göre beklenen değerlerin yüzdesi olarak değerlendirilmiştir. Solunum fonksiyon testinde birinci saniyedeki zorlu ekspiratuar volüm $\left(\mathrm{FEV}_{1}\right)$, zorlu vital kapasite (FVC), birinci saniyedeki zorlu ekspiratuar volümün zorlu vital kapasiteye oranı $\left(\mathrm{FEV}_{1} / \mathrm{FVC}\right)$, tepe akım hızı (PEF), zorlu ekspiratuar volümün \% 25-75 $\left(\% \mathrm{FEF}_{25-75}\right)$ akım hızı değeri, $\% \mathrm{FEF}_{50}$ akım hızı değeri, maksimal istemli ventilasyon (MVV), inspiratuar kapasite (IC), vital kapasite (VC), rezidual volüm (RV) ve total akciğer kapasitesi (TLC) ölçümleri yapılmıştır. (Şekil 3.1). 


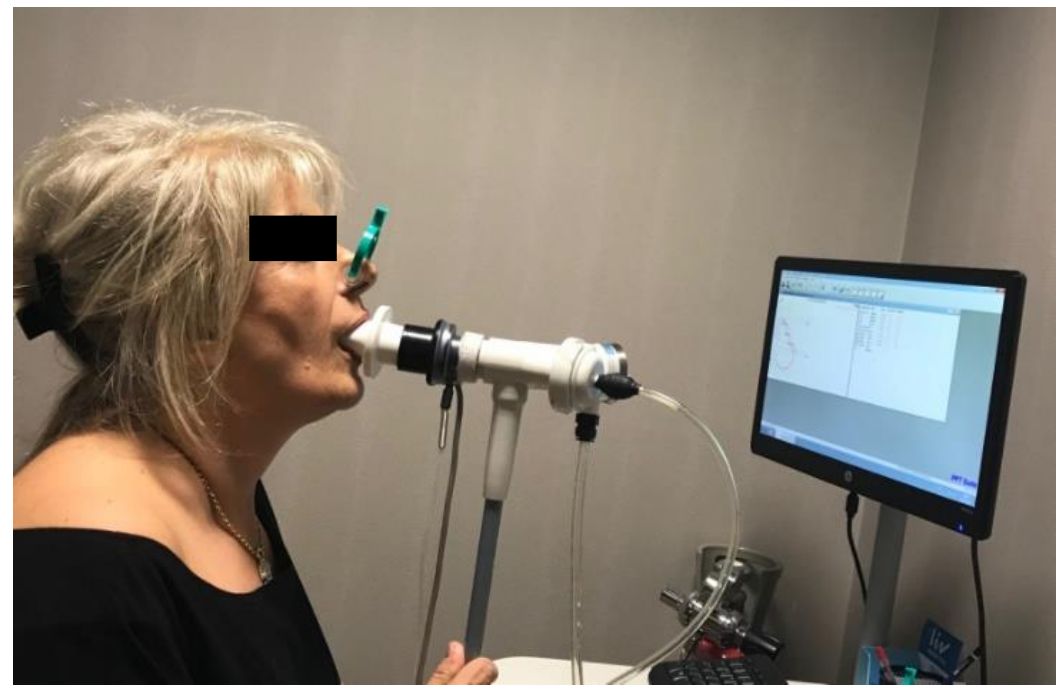

Şekil 3.1. Solunum Fonksiyon Testi.

\section{-Diffüzyon Kapasitesi Testi}

$\mathrm{Bu}$ testle, vücudun oksijen ihtiyacını karşılayıp karşılamadığı belirlenir. Test sırasında organizmaya zarar vermediği bilinen karbonmonoksit (CO) ve helium (HE) gazı kullanılarak akciğer hacimleri ölçülür; böylece solunum havasının ne kadar alındığı ve bunun içindeki CO yardımıyla ne kadar gazın kana geçtiği saptanmış olur $(41,58)$.

$\mathrm{Bu}$ test, hava keseciklerinin ve onların çevresindeki damarların ne kadar etkin görev yaptığını saptamak için hastalara uygulanmış ve önceden hastaya test işlemi ile ilgili bilgi verilmiştir. Test için hastanın burnu yumuşak bir mandal ile kapatılarak önce derin bir ekspirasyon ile akciğerdeki havayı boşaltması istenmiştir. Daha sonra spirometrenin ağızlığını boşluk bırakmadan ağzının içine alıp normal nefes alıp vermesi istenmiştir. Normal nefes alıp verirken cihazın gaz haznesi hazır olduğunda, hastadan tüm nefesini kuvvetlice vermesi istenmiştir ve gaz vermesi için cihazın başlatma tuşuna basılması ile beraber hastadan cihazın verdiği gazı içine çekebildiği kadar çekmesi ve 10 saniye boyunca kaçırmadan tutması istenmiştir. Daha sonra tüm nefesi boşaltması istenip test sonlandırılmıştır (20, 55, $56)$. 


\subsubsection{Egzersiz Kapasitesinin Değerlendirilmesi}

KOAH'lı hastaların egzersiz kapasitesi, 6 dakikalık yürüme testi (6DYT) ile değerlendirilmiştir $(72,73)$. 6DYT, aynı gün, yarım saat arayla, iki defa bireylere uygulanmıştır. Test yapılmadan önce bireyler 10 dakika süre ile istirahat edilmiştir. Teste başlamadan önce bireylere, test sırasında dispne hissi hissederlerse; durup dinlenebilecekleri ve bu sürenin teste dahil edileceği belirtilmiştir. Bireylerden 30 metrelik düz bir koridorda 6 dakika süre boyunca kendi yürüme hızlarında olabildiğince hızlı yürümeleri istenmiştir $(74,75)$. Yürüme mesafeleri metre cinsinden değerlendirmeye alınmıştır. Ayrıca 6DYT sonrası bireylerin aktivite sonrası ağrı (VAS) seviyeleri değerlendirilmiştir.

\subsubsection{Kas Kuvvetinin Değerlendirilmesi}

Kalça çevresi kasları ve alt ekstremitenin diğer kasları (gastroknemius, hamstringler, kuadriceps) ile abdominal kaslar ve sirt ekstansörlerinin kasları manuel kas testi ile ölçülmüştür. Manuel kas testi için Lovett'in manuel kas testi kullanılmıştır $(76,77)$. Kas kuvveti 0 en düşük 5 en yükssek puan cinsinden değerlendirilmiştir.

\subsubsection{Anksiyete ve Depresyonun Değerlendirilmesi}

Hastaların depresyon düzeyleri, Beck Depresyon Anketi ile, anksiyete düzeyleri Beck Anksiyete Ölçeği ile değerlendirilmeye alınmıştır. Her iki ölçek 21 sorudan oluşur ve her bir soru 0-3 puan aralığında derecelenir. Bu skala, bedensel hastalığı olan hastalar ve birinci basamak sağlık hizmetlerine başvuranlar için kullanılır. Toplam 14 sorudan yedisi (tek sayılar) anksiyeteyi ve yedisi (çift sayılar) depresyonu ölçmektedir. Skalada hastaların anksiyete ve depresyon alt ölçeklerinden alabilecekleri en düşük puan 0 iken en yüksek puan 21 'dir.Puan yükseldikçe, depresyonun veya anksiyetenin şiddeti artar (78). Depresyonu değerlendirmek için güvenirlik ve geçerliliği Tuğlu ve ark. tarafından 2005 yılında yapılan Beck Depresyon Anketinin Türkçe versiyonu (79), anksiyete için ise Beck Anksiyete Ölçeğinin Gülten Seber ve arkadaşları tarafından yapılan Türkçe versiyonu kullanılmıştır (80). (Ek Tablo 5-6) 


\subsubsection{Yaşam Kalitesinin Değerlendirilmesi}

Yaşam kalitesinin düzeyi, Sağlık Değerlendirme Anketi (Health Assessment Questionnaire $=H A Q)$ ve Klsa form SF36 anketleri ile değerlendirilmeye alınmıştır. Sağlık Değerlendirme Anketi (HAQ) 20 sorudan oluşur ve 0-60 arası puan ile derecelendirilir (81). Kısa form SF36 ise 9 bölümden oluşur (82). Anketin Türk popülasyonu için geçerlik ve güvenirlik çalışması yapılmıştır (83). (Ek Tablo 7-8)

\subsubsection{Kemik Mineral Yoğunluğu}

Hastaların kemik mineral yoğunlukları kemik mineral dansitometrisi (BMD) yapılarak ölçülmüştür. Horizon DXA, San Diego, USA ile değerlendirmeye alınılmıştır. Hastalar soyunup önlük giyindikten sonra tetkik masasına yatmaları istenmiştir. Masanın alt tarafında $X$ ışını üreten jeneratör ve üst tarafında da $X$ 1şınlarını toplayan dedektör bulunmaktadır. Omurga ve kalça kemikliklerindeki kemik kayıpları üzerinde yoğunlaşılır. Test sonuçları iki şekilde skorlanır. T skoru, aynı cinsiyette maksimum kemik yoğunluğuna sahip genç erişkin ile karşılaştırıldığında hastanın kemik yoğunluğu düzeyini gösterir.

-1 'in üzerinde değerler normaldir.

-1 ile -2,5 arasındaki değerler kemik kaybının ilk safhası olan osteopeniyi gösterir

$-2,5$ 'tan küçük değerler ise osteoporoz lehine yorumlanır.

Z skoru, aynı yaş grubunda, aynı ölçülerde ve aynı cinsiyetteki bireyler ile karşılaştığında hastanın kemik miktarını gösterir. Çok yüksek ve alçak değerlerde ileri tetkik gerekmektedir.

\section{4. İstatistiksel Analiz}

İstatistiksel analizler, Windows tabanlı için SPSS 25 istatistik paket program kullanılarak gerçekleştirildi. Gruplara ilişkin niteliksel değişkenler frekans ve yüzde ile; nicel veriler ise ortalama, ortanca, standart sapma, minimum ve maksimum şeklinde özetlenmiştir. "Çalışma verileri değerlendirilirken parametrelerin normal dağılıma uygunluğu ShapiroWilks testi ile değerlendirilmiş ve parametrelerin normal dağılım gösterdiği saptanmıştır. Bağımsız gruplarda karşılaştırmalar “İki Ortalama 
Arasındaki Farkın Anlamlılık Testi (Student-t test)" ile test edilmiş, fark bulunan değişkenlerde etki büyüklügünün karşılaştırılması için “Cohen'in d etki büyüklüğü” hesaplanmıştır. KOAH Grubundaki parametrelerin grup içi karşılaştırılmalarında "Eşleştirilmiş Gruplarda t Testi (Paired Samples-t Test)" kullanılmıştır. Verilerin analizi, \%95 güven aralığında ve $\mathrm{p}<0,05$ düzeyindeki anlamlılık düzeyine göre değerlendirilmiştir. 


\section{BULGULAR}

Çalışmamız KOAH'lı hastalarla KOAH hastalığı olmayan sağlıklı bireylerin; solunum fonksiyonları, egzersiz kapasitesi, yaşam kalitesi, anksiyete ile birlikte ağrı, kas kuvveti ve kemik mineral yoğunluğunun incelenmesi amacı ile planlanmıştır. Değerler gruplar arasında ve bazı parametreler KOAH grubu içerisinde karşılaştırılmıştır. Değerler Ortalama \pm Standart Sapma ve (Minimum Maksimum) şeklinde belirtilmiştir.

\subsection{Demografik Özellikler}

Çalışmamıza toplam 75 kişi dahil edilmiştir. 40 kişiden oluşan GOLD evre I ve II tanılı KOAH Grubunda 21 erkek (\% 52) ve 19 kadın (\% 48), Kontrol grubunda ise 21 erkek (\% 60) ve 14 kadın (\% 40) katılımcı bulunmaktadır. KOAH grubundaki katılımcıların yaş ortalamaları 61,63 \pm 6,02 yıl iken Kontrol grubunun 61,17 \pm 4,44 yıldır. KOAH grubunun ortalama boy, vücut ağırlığı ve VKİ'si sırasıyla 167,23 \pm $9.03 \mathrm{~cm}, 70,35 \pm 10,12 \mathrm{~kg}$ ve $25,22 \pm 2,41 \mathrm{~kg} / \mathrm{m}^{2}$ olarak hesaplanmıştır. Benzer şekilde Kontrol grubunun boy, vücut ağırlığı ve VKİ ortalaması sırasıyla şu şekilde bulunmuştur: $168,97 \pm 8,88 \mathrm{~cm}, 71,77 \pm 8,47 \mathrm{~kg}$ ve $21,55 \pm 2,75 \mathrm{~kg} / \mathrm{m}^{2}$.

Gruplardaki bireylerin demografik özellikleri (yaş, vücut ağırlığı, boy ve VKİ) bakımından istatistiksel açıdan anlamlı bir fark olmadığı ve grupların demografik özellikleri açısından birbirine benzer olduğu bulunmuştur $(p>0,05)$ (Tablo 4.1). 
Tablo 4.1. Grupların Demografik Özellikleri.

\begin{tabular}{|c|c|c|c|c|}
\hline & $\begin{array}{c}\text { KOAH Grubu } \\
\text { Ort } \pm \text { SS } \\
\text { (Min }- \text { Maks })\end{array}$ & $\begin{array}{c}\text { KONTROL } \\
\text { Grubu } \\
\text { Ort } \pm \text { SS } \\
\text { (Min - Maks) }\end{array}$ & $\mathbf{t}$ & $\mathbf{p}$ \\
\hline Yaş (y1l) & $\begin{array}{c}61,63 \pm 6,02 \\
(49-69)\end{array}$ & $\begin{array}{c}61,17 \pm 4,44 \\
(53-69)\end{array}$ & 0,366 & 0,715 \\
\hline Boy (cm) & $\begin{array}{c}167,23 \pm 9,03 \\
(153-184)\end{array}$ & $\begin{array}{c}168,97 \pm 8,88 \\
(151-182)\end{array}$ & 0,842 & 0,403 \\
\hline Vücut Ağırlığg $(\mathrm{kg})$ & $\begin{array}{c}70,35 \pm 10,12 \\
(52-95)\end{array}$ & $\begin{array}{c}71,77 \pm 8,47 \\
(55-88)\end{array}$ & 0,654 & 0,515 \\
\hline VKİ $\left(\mathrm{kg} / \mathrm{m}^{2}\right)$ & $\begin{array}{l}25,22 \pm 2,41 \\
(20.1-30.1)\end{array}$ & $\begin{array}{l}21,55 \pm 2,75 \\
(16.3-29.3)\end{array}$ & 0,646 & 0,520 \\
\hline
\end{tabular}

Kısaltmalar: Ort: Ortalama Değer, SS: Standart Sapma, Min: Minimum, Maks: Maksimum, p: Yanılma Olasılığı, t: İki Ortalama Arasındaki Farkın Önemlilik Testi Değeri, VKİ: Vücut kütle indeksi.

\subsection{Sigara Tüketimi}

Çalışmamıza katılmış 75 katılımcıdan KOAH grubundaki hastaların \% 97,5'i ile kontrol grubundaki katılımcıların \% 48,6'sı çalışma öncesinde sigara kullanmadıklarını belirtmiştir. KOAH grubunun sigara bırakma yılı ortalama 4,28 \pm 5,29 y1l iken Kontrol grubunun 1,17 \pm 2,59 yıldır (Tablo 4.2). İki grup arasında sigarayı bırakma süresi bakımından istatistiksel olarak anlamlı bir fark vardır $(\mathrm{p}=0,002)($ Tablo 4.2). KOAH grubundaki $(\mathrm{n}=40) 14$ kişi (\%35) 0-10 yıl arasında, 4 kişi (\%10) 10-19 yıl arasında, 7 kişi (\%17,5) 20-29 yıl arasında, 10 kişi (\%25) 30-39 yıl arasında ve 5 kişi $(\% 12,5)$ de 40 yıldan fazla bir süre sigara içtiğini bildirmiştir. Kontrol grubundaki (n=35) 15 kişi $(\% 42,9)$ 0-10 yıl arasında, 12 kişi $(\% 34,1)$ 10-19 yıl arasında, 7 kişi $(\% 20,1)$ 20-29 yıl arasında ve bir kişi $(\% 2,9)$ de 32 yıl sigara içtiğini belirtmiştir. İki gruptaki katılımcılar sigara içme süresi bakımından karşılaştırıldığında KOAH grubunun kontol grubundan daha fazla olduğu ve farkın istatistiksel olarak anlamlı olduğu bulunmuştur $(p=0,007)$ (Tablo 4.2). Gruplar günlük sigara tüketme adetleri karşılaştırıldığında, iki grup arasında istatistiksel olarak anlamlı bir fark bulunmamıştır ( $\mathrm{p}=0,230)$ (Tablo 4.2). 
Tablo 4.2. Grupların Sigara Tüketimi.

\begin{tabular}{|l|c|c|c|c|}
\hline & $\begin{array}{c}\text { KOAH Grubu } \\
\text { Ort } \pm \text { SS } \\
\text { (Min }- \text { Maks) }\end{array}$ & $\begin{array}{c}\text { KONTROL } \\
\text { Grubu } \\
\text { Ort } \pm \text { SS } \\
\text { Min }- \text { Maks })\end{array}$ & $\mathbf{t}$ & $\mathbf{p}$ \\
\hline Sigara içme (yıl) & $\begin{array}{c}19,50 \pm 16,14 \\
(0-42)\end{array}$ & $\begin{array}{c}11,09 \pm 9,65 \\
(0-32)\end{array}$ & 2,778 & $\mathbf{0 , 0 0 7 *}$ \\
\hline $\begin{array}{l}\text { Sigarayı birakma } \\
\text { (y1l) }\end{array}$ & $\begin{array}{c}4,28 \pm 5,29 \\
(0-20)\end{array}$ & $\begin{array}{c}1,17 \pm 2,59 \\
(0-10)\end{array}$ & 3,295 & $\mathbf{0 , 0 0 2 *}$ \\
\hline $\begin{array}{l}\text { Sigara tüketim } \\
\text { miktar1 (adet/gün) }\end{array}$ & $\begin{array}{c}13,25 \pm 13,84 \\
(0-60)\end{array}$ & $\begin{array}{c}9,83 \pm 9,98 \\
(0-40)\end{array}$ & 1,212 & 0,230 \\
\hline
\end{tabular}

Kısaltmalar: Ort: Ortalama Değer, SS: Standart Sapma, Min: Minimum, Maks: Maksimum, p: Yanılma Olasılı̆̆l, $t$ : İki Ortalama Arasındaki Farkın Önemlilik Testi Değeri (*p<0,05)

\section{3. Ăgrı}

Ağrıyı değerlendirmek için Vizüel Analog Skala (VAS) kullanılmıştır. Değerlendirme Altı Dakika Yürüme Testi sonrası (aktivite sonrası ağrısı) ve gece (istirahat ağrısı) için ayrı ayrı yapıldı. 6DYT sonrası VAS skoru iki grup arasında KOAH grubunda daha yüksek olup istatistiksel olarak anlamlı bulunmuştur $(\mathrm{p}=0,000)$ (Tablo 4.3). Gece ağrısı bakımından KOAH grubu kontrol grubuna göre yine yüksek bulunmuş ve istatistiksel olarak anlamlı çıkmıştır. $(\mathrm{p}=0,001)$ (Tablo 4.3).

Tablo 4.3. Grupların ağrı parametrelerinin karşılaştırılması.

\begin{tabular}{|l|c|c|c|c|}
\hline & $\begin{array}{c}\text { KOAH Grubu } \\
\text { Ort } \pm \text { SS } \\
\text { (Min - Maks) }\end{array}$ & $\begin{array}{c}\text { KONTROL } \\
\text { Grubu } \\
\text { Ort } \pm \text { SS } \\
\text { (Min - Maks) }\end{array}$ & $\mathbf{t}$ & $\mathbf{p}$ \\
\hline $\begin{array}{l}\text { 6DYT Sonrası } \\
\text { Ağr1 VAS Skoru }\end{array}$ & $6,53 \pm 1,08$ & $3,71 \pm 2,02$ & 7,346 & $<\mathbf{0 , 0 0 1}{ }^{*}$ \\
\hline $\begin{array}{l}\text { Gece İstirahatte } \\
\text { Ağr1 VAS Skoru }\end{array}$ & $2,40 \pm 1,19$ & $1,63 \pm 0,73$ & 3,419 & $\mathbf{0 , 0 0 1} *$ \\
\hline
\end{tabular}

Kısaltmalar: Ort: Ortalama Dĕger, SS: Standart Sapma, Min: Minimum, Maks: Maksimum, p: Yanılma Olasılı̆̆l, t: İki Ortalama Arasındaki Farkın Önemlilik Testi Değeri, 6DYT: 6 Dakika Yürüme Testi, VAS: Görsel Analog Ölçĕgi 


\subsection{Postür}

Çalışmaya katılan toplam 75 kişiden KOAH Grubunda (n=40) 19'unda $(\% 47,5)$, Kontrol Grubunda (n=35) 11'inde $(\% 31,4)$ kifoz bulguları saptanmıştır. KOAH Grubunda $(n=40) 5(\% 12,5)$ ve Kontrol Grubunda $(n=35) 2$ kişide $(\% 5,7)$ skolyoz, KOAH Grubunda 12 kişide (\%30) ve Kontrol Grubunda 9 kişide $(\% 25,4)$ lordoz gözlemlenmiştir. KOAH Grubundaki 40 kişinin 12'sinde (\%30) ve 35 kişilik Kontrol Grubunun 5'inde (\%14,3) çökük gögüus gözlemlenmiştir. 14 kişi (\%35) KOAH Grubundan ve 6 kişi $(\% 17,1)$ Kontrol Grubundan olmak üzere toplam 20 kişide fiçı göğüs fenotipi saptanmıştır.

Tablo 4.4. Grupların Postür Parametrelerinin Karşılaştırılması.

\begin{tabular}{|c|c|c|c|c|c|c|}
\hline & \multicolumn{3}{|c|}{$\begin{array}{l}\text { KOAH } \\
\text { Grubu }\end{array}$} & \multicolumn{3}{|c|}{$\begin{array}{c}\text { KONTROL } \\
\text { Grubu }\end{array}$} \\
\hline & & $\mathrm{n}$ & $\%$ & $\mathrm{n}$ & $\%$ & $\mathrm{p} *$ \\
\hline KİFOZ & $\begin{array}{l}\text { YOK } \\
\text { VAR }\end{array}$ & $\begin{array}{l}24 \\
11\end{array}$ & $\begin{array}{l}68,6 \% \\
31,4 \%\end{array}$ & $\begin{array}{l}21 \\
19\end{array}$ & $\begin{array}{l}52,5 \% \\
47,5 \%\end{array}$ & 0,237 \\
\hline SKOLYOZ & $\begin{array}{l}\text { YOK } \\
\text { VAR }\end{array}$ & $\begin{array}{c}30 \\
5\end{array}$ & $\begin{array}{l}85,7 \% \\
14,3 \%\end{array}$ & $\begin{array}{c}35 \\
5\end{array}$ & $\begin{array}{l}87,5 \% \\
12,5 \%\end{array}$ & 0,999 \\
\hline LORDOZ & $\begin{array}{l}\text { YOK } \\
\text { VAR }\end{array}$ & $\begin{array}{c}26 \\
9\end{array}$ & $\begin{array}{l}74,3 \% \\
25,7 \%\end{array}$ & $\begin{array}{l}28 \\
12\end{array}$ & $\begin{array}{l}70,0 \% \\
30,0 \%\end{array}$ & 0,798 \\
\hline $\begin{array}{l}\text { DÜŞÜKK } \\
\text { OMUZ }\end{array}$ & $\begin{array}{l}\text { YOK } \\
\text { VAR }\end{array}$ & $\begin{array}{l}23 \\
12\end{array}$ & $\begin{array}{l}65,7 \% \\
34,3 \%\end{array}$ & $\begin{array}{l}22 \\
18\end{array}$ & $\begin{array}{c}55,0 \% \\
45 \%\end{array}$ & 0,479 \\
\hline $\begin{array}{l}\text { ÇÖKÜK } \\
\text { GÖĞÜS }\end{array}$ & $\begin{array}{l}\text { YOK } \\
\text { VAR }\end{array}$ & $\begin{array}{c}30 \\
5\end{array}$ & $\begin{array}{l}85,7 \% \\
14,3 \%\end{array}$ & $\begin{array}{l}28 \\
12\end{array}$ & $\begin{array}{l}70,0 \% \\
30,0 \%\end{array}$ & 0,166 \\
\hline $\begin{array}{l}\text { FIÇI } \\
\text { GÖĞÜS }\end{array}$ & $\begin{array}{l}\text { YOK } \\
\text { VAR }\end{array}$ & $\begin{array}{c}29 \\
6\end{array}$ & $\begin{array}{l}82,9 \% \\
17,1 \%\end{array}$ & $\begin{array}{l}26 \\
14\end{array}$ & $\begin{array}{l}65,0 \% \\
35,0 \%\end{array}$ & 0,117 \\
\hline
\end{tabular}

Pearson Chi-Square Test, Fisher's Exact Test Kısaltmalar: n:Örneklerin sayıs1 \%: Yüzde değeri p:Yanılma olasılı̆̆ $1 * \mathrm{p}<0,05$

\subsection{Solunum Fonksiyon Testleri}

İki grup solunum fonksiyon testi sonuçları incelendiğinde $\mathrm{FVC} \%, \mathrm{FEV}_{1} \%$, $\mathrm{FEV}_{1} / \mathrm{FVC}$ oran1, $\mathrm{FEF}_{25-75} \%$ oranları her parametrede $\mathrm{KOAH}$ grubunda daha düşük olup istatiksel olarak anlamlı bulunmuştur (Tablo 4.5). KOAH grubunda ortalama FVC(\%) 56,40 \pm 14,12 iken Kontrol grubunda 94,12 \pm 7,85 bulunmuş olup aradaki bu fark istatistiksel olarak anlamlıdır $(\mathrm{p}<0,01)$. Benzer şekilde $\mathrm{FEV}_{1} \%$ ve $\mathrm{FEV}_{1} / \mathrm{FVC}$ oranı da KOAH grubunun daha düşük olması sebebiyle istatistiksel olarak anlamlı bulunmuştur $(p<0,01)$. Diffüzyon kapasitesini ölçen DLCO için KOAH ve Kontrol 
grubunda sırasıyla ortalama $\% 57,75 \pm 12,60$ ve $\% 81,23 \pm 9,94$ bulunmuştur ve iki grup arasındaki fark istatistiksel olarak anlamlıdır $(\mathrm{p}<0,01)$.

Tablo 4.5. Grupların Solunum Fonksiyon Test Parametrelerinin Karşılaştırılması.

\begin{tabular}{|l|c|c|c|c|}
\hline & $\begin{array}{c}\text { KOAH Grubu } \\
\text { Ort } \pm \text { SS } \\
(\text { Min }- \text { Maks) }\end{array}$ & $\begin{array}{c}\text { KONTROL } \\
\text { Grubu } \\
\text { Ort } \pm \text { SS } \\
\text { (Min - Maks) }\end{array}$ & $\mathbf{t}$ & $\mathbf{p}$ \\
\hline $\mathrm{FVC}(\%)$ & $\begin{array}{c}56,40 \pm 14,12 \\
(30-86)\end{array}$ & $\begin{array}{c}94,12 \pm 7,85 \\
(78-108)\end{array}$ & $-14,530$ & $<0,001^{*}$ \\
\hline $\mathrm{FEV}_{1}(\%)$ & $\begin{array}{c}54,03 \pm 18,92 \\
(22-86)\end{array}$ & $\begin{array}{c}95,37 \pm 6,97 \\
(78-106)\end{array}$ & $-12,855$ & $<0,001^{*}$ \\
\hline $\mathrm{FEV}_{1} / \mathrm{FVC}$ & $\begin{array}{c}68,43 \pm 17,26 \\
(\%)\end{array}$ & $\begin{array}{c}103,31 \pm 6,92 \\
(88-119)\end{array}$ & $-10,065$ & $<0,001^{*}$ \\
\hline $\mathrm{FEF}_{25-75}(\%)$ & $\begin{array}{c}25,22 \pm 2,41 \\
(7-90)\end{array}$ & $\begin{array}{c}21,55 \pm 2,75 \\
(76-109)\end{array}$ & $-18,225$ & $<0,001^{*}$ \\
\hline $\mathrm{DLCO}(\%)$ & $\begin{array}{c}57,75 \pm 12,60 \\
(34-85)\end{array}$ & $\begin{array}{c}81,23 \pm 9,94 \\
(62-104)\end{array}$ & $-9,008$ & $<0,001^{*}$ \\
\hline
\end{tabular}

Kısaltmalar: Ort: Ortalama Değer, SS: Standart Sapma, Min: Minimum, Maks: Maksimum, p: Yanılma Olasıllğgl, t: İki Ortalama Arasındaki Farkın Önemlilik Testi Değeri, FEF 25-75\%: Zorlu Vital Kapasitenin \%25-75 Akım Hızl, FEV ${ }_{1}$ : Birinci Saniyedeki Zorlu Ekspiratuar Volüm, FEV $/$ FVC: Birinci Saniyedeki Zorlu Ekspiratuar Volümün Zorlu Vital Kapasiteye Oranı, FVC: Zorlu Vital Kapasite, DLCO: Difüzyon Kapasitesi. *p<0,05

\subsection{Egzersiz Kapasitesi}

Fonksiyonel kapasiteyi değerlendirmek için yapılmış olan 6DYT gruplar arasında; KOAH grubunun $\mathrm{KOAH}$ olmayan bireylere kıyasla daha düşük olması sebebiyle iki grup arası fark istatistiksel olarak anlamlı bulunmuştur $(p<0,001$, $\mathrm{p}<0,05)$. (Tablo 4.6)

Tablo 4.6. Grupların egzersiz kapasitelerinin karşılaştırılması.

\begin{tabular}{|l|c|c|c|c|}
\hline & $\begin{array}{c}\text { KOAH Grubu } \\
\text { Ort } \pm \text { SS }\end{array}$ & $\begin{array}{c}\text { KONTROL } \\
\text { Grubu } \\
\text { Ort } \pm \text { SS }\end{array}$ & t & p \\
\hline 6DYT (metre) & $369,13 \pm 64,91$ & $499,57 \pm 67,08$ & $-8,548$ & $<\mathbf{0 , 0 0 1 *}$ \\
\hline
\end{tabular}

Kısaltmalar: Ort: Ortalama Değer, SS: Standart Sapma, Min: Minimum, Maks: Maksimum, p: Yanılma Olasılığ l, t: İki Ortalama Arasındaki Farkın Önemlilik Testi Değeri, 6DYT: 6 Dakika Yürüme Testi. *p< $<\mathbf{0 , 0 5}$ 


\subsection{Kas Kuvveti}

KOAH ve Kontrol Gruplarının Gastroknemius, Hamstring, Kuadriseps, Abdominaller ve Sırt Ekstansörleri kas kuvvetleri karşılaştırılmıştır. Gastroknemius ve Abdominel kas kuvveti KOAH grubunda daha az olup iki grup arasinda istatistiksel olarak anlamlıdır (sırasıyla $p=0,029, p<0,001$ ) Hamstring, Kuadriseps ve Sırt Ekstansörleri arasındaki fark iki grup karşılaştırıldığında anlamlı bulunmamıştır (p>0,05). (Tablo 4.7)

Tablo 4.7. Grupların kas kuvveti karşılaştırılması.

\begin{tabular}{|l|c|c|c|c|}
\hline & $\begin{array}{c}\text { KOAH Grubu } \\
\text { Ort } \pm \text { SS } \\
\text { (Min }- \text { Maks) }\end{array}$ & $\begin{array}{c}\text { KONTROL } \\
\text { Grubu } \\
\text { Ort } \pm \text { SS } \\
\text { (Min - Maks) }\end{array}$ & $\mathbf{t}$ & $\mathbf{p}$ \\
\hline Gastroknemius & $\begin{array}{c}4,80 \pm 0,24 \\
(4-5)\end{array}$ & $\begin{array}{c}4,92 \pm 1,25 \\
(4-5)\end{array}$ & $-2,223$ & $\mathbf{0 , 0 2 9 *}$ \\
\hline Hamstring & $\begin{array}{c}4,82 \pm 0,20 \\
(4.5-5)\end{array}$ & $\begin{array}{c}4,88 \pm 0,17 \\
(4.5-5)\end{array}$ & $-1,366$ & 0,176 \\
\hline Kuadriseps & $\begin{array}{c}4,81 \pm 0,21 \\
(4.5-5)\end{array}$ & $\begin{array}{c}4,87 \pm 0,19 \\
(4.5-5)\end{array}$ & 0,869 & 0,388 \\
\hline Abdominaller & $\begin{array}{c}4,56 \pm 0,24 \\
(4.25-5)\end{array}$ & $\begin{array}{c}4,85 \pm 0,22 \\
(4.25-5)\end{array}$ & $-5,352$ & $<\mathbf{0 , 0 0 1 *}$ \\
\hline Sirt Ekstansörleri & $\begin{array}{c}4,85 \pm 0,19 \\
(4.5-5)\end{array}$ & $\begin{array}{c}4,90 \pm 0,15 \\
(4.5-5)\end{array}$ & $-1,251$ & 0,215 \\
\hline
\end{tabular}

Kisaltmalar: Ort: Ortalama Değer, SS: Standart Sapma, Min: Minimum, Maks: Maksimum, p: Yanılma Olasılı̆̆ , t: İki Ortalama Arasındaki Farkın Önemlilik Testi Değeri.

\subsection{Anksiyete- Depresyon}

Anksiyete, Beck Anksiyete Ölçeği ile depresyon ise Beck Depresyon ölçeği ile ölçülmüş olup iki grup arasındaki fark KOAH grubunun değerlerinin daha yüksek çıkmış olmasından dolayı istatistiksel olarak anlamlı bulunmuştur (sırasıyla $\mathrm{p}=0,001$, $\mathrm{p}<0,001$ ) (Tablo 4.8). 
Tablo 4.8. Grupların BECK Anksiyete Ölçeği ve BECK Depresyon Ölçeği Değerleri Karşılaştırmaları.

\begin{tabular}{|l|c|c|c|c|}
\hline & $\begin{array}{c}\text { KOAH Grubu } \\
\text { Ort } \pm \text { SS } \\
\text { (Min }- \text { Maks) }\end{array}$ & $\begin{array}{c}\text { KONTROL } \\
\text { Grubu } \\
\text { Ort } \pm \text { SS } \\
\text { (Min }- \text { Maks) }\end{array}$ & $\mathbf{t}$ & $\mathbf{p}$ \\
\hline $\begin{array}{l}\text { BECK } \\
\text { Depresyon } \\
\text { Ölçeği }\end{array}$ & $\begin{array}{c}14,88 \pm 3,14 \\
(6-22)\end{array}$ & $\begin{array}{c}12,83 \pm 3,56 \\
(6-21)\end{array}$ & $-2,639$ & $<\mathbf{0 , 0 0 1 *}$ \\
\hline $\begin{array}{l}\text { BECK } \\
\text { Anksiyete } \\
\text { Ölçeği }\end{array}$ & $\begin{array}{c}20,23 \pm 4,64 \\
(13-29)\end{array}$ & $\begin{array}{c}1,63 \pm 0,73 \\
(6-21)\end{array}$ & $-7,552$ & $<\mathbf{0 , 0 0 1 *}$ \\
\hline
\end{tabular}

Kisaltmalar: Ort: Ortalama Dĕger, SS: Standart Sapma, Min: Minimum, Maks: Maksimum, p: Yanılma Olasılı̆̆ı̆ t: İki Ortalama Arasındaki Farkın Önemlilik Testi Değeri.

$* \mathbf{p}<\mathbf{0 , 0 5}$

\subsection{Yaşam Kalitesi}

Yaşam kalitesi için değerlendirilmeye alınan gruplar öncelikle SF36 anketi ile değerlendirilmiştir. SF-36 anketinin tüm parametrelerinde KOAH grubu kontrol grubuna göre daha düşük değerlerde olup grupların farkları istatistiksel olarak anlamlı bulunmuştur $(* \mathrm{p}<0,05)($ Tablo 4.9$)$.

Yaşam kalitesini değerlendirmek için kullanılan bir diğer anket HAQ için iki grup arasında yine KOAH grubu aleyhine istatiksel olarak anlamlı fark bulunmuştur. $\left({ }^{*} \mathrm{p}<0,05\right)$ (Tablo 4.9). 
Tablo 4.9. Grupların Yaşam Kalitesi Anketlerinin Karşılaştırılması.

\begin{tabular}{|c|c|c|c|c|}
\hline & $\begin{array}{c}\text { KOAH Grubu } \\
\text { Ort } \pm \text { SS } \\
\text { (Min }- \text { Maks })\end{array}$ & $\begin{array}{c}\text { KONTROL } \\
\text { Grubu } \\
\text { Ort } \pm \text { SS } \\
\text { (Min - Maks) }\end{array}$ & $\mathbf{t}$ & $\mathbf{p}$ \\
\hline HAQ & $\begin{array}{c}34,08 \pm 5,51 \\
(24-47)\end{array}$ & $\begin{array}{c}3,77 \pm 4,03 \\
(0-12)\end{array}$ & $-26,841$ & $<0,001 *$ \\
\hline SF-36 Fiziksel Fonksiyon & $\begin{array}{c}33,84 \pm 19,52 \\
(5.5-77.7)\end{array}$ & $\begin{array}{l}77,72 \pm 14,56 \\
(44.4-94.4)\end{array}$ & 10,900 & $<0,001 *$ \\
\hline SF-36 Rol Kisitlamaları & $\begin{array}{l}12,50 \pm 17,90 \\
(0-50)\end{array}$ & $\begin{array}{l}62,14 \pm 22,98 \\
(25-100)\end{array}$ & 10,499 & $<0,001 *$ \\
\hline SF-36 Vücut Ağrıs1 & $\begin{array}{c}45,50 \pm 15,69 \\
(10-77.5) \\
\end{array}$ & $\begin{array}{c}82,57 \pm 13,10 \\
(57.50-100)\end{array}$ & 11,011 & $<0,001 *$ \\
\hline SF-36 Sosyal Fonksiyon & $\begin{array}{c}62,50 \pm 17,21 \\
(12.5-87.5) \\
\end{array}$ & $\begin{array}{c}76,78 \pm 15,79 \\
(90-100) \\
\end{array}$ & 3,725 & $<0,001 *$ \\
\hline $\begin{array}{l}\text { SF-36 Genel Ruh Sağlığı } \\
\text { Durumu }\end{array}$ & $\begin{array}{l}57,30 \pm 10,30 \\
(40-76)\end{array}$ & $\begin{array}{l}77,26 \pm 13,88 \\
(44-92)\end{array}$ & 7,124 & $<0,001 *$ \\
\hline SF-36 Emosyonel Durum & $\begin{array}{c}14,98 \pm 18,39 \\
(0-66.6)\end{array}$ & $\begin{array}{c}68,53 \pm 25,50 \\
(33.3-100)\end{array}$ & 10,519 & $<0,001 *$ \\
\hline SF-36 Enerji/Yorgunluk & $\begin{array}{l}35,25 \pm 18,07 \\
(15-85)\end{array}$ & $\begin{array}{c}79,86 \pm 17,66 \\
(45-100)\end{array}$ & 10,714 & $<0,001 *$ \\
\hline SF-36 Genel Sağlık Algıs1 & $\begin{array}{c}43,38 \pm 10,76 \\
(30-60)\end{array}$ & $\begin{array}{l}76,86 \pm 9,08 \\
(60-90)\end{array}$ & 14,443 & $<0,001 *$ \\
\hline $\begin{array}{l}\text { SF-36 Geçen Y1la Oranla } \\
\text { Sağlık Durumu }\end{array}$ & $\begin{array}{l}11,25 \pm 15,96 \\
(0-50)\end{array}$ & $\begin{array}{l}45,71 \pm 17,66 \\
(25-75)\end{array}$ & 8,876 & $<0,001 *$ \\
\hline
\end{tabular}

Kisaltmalar: Ort: Ortalama Değer, SS: Standart Sapma, Min: Minimum, Maks: Maksimum, p: Yanılma Olasılı̆̆l, $t$ : İki Ortalama Arasındaki Farkın Önemlilik Testi Değeri, HAQ: Health assessment SF-36: Kısa Form-36 (*p<0,005)

\subsection{Kemik Mineral Yoğunluğu}

Kemik mineral yoğunluğu değerlendirilmeye alındığında KOAH Grubu ile Kontrol Grubunda değişkenlerinin hiçbirinde istatistiksel olarak anlamlı fark bulunmamıştır ( $\mathrm{p}>0,005)$ (Tablo 4.10). 
Tablo 4.10. Grupların Kemik Mineral Yoğunluğu Değerleri Karşılaştırılması.

\begin{tabular}{|l|c|c|c|c|}
\hline & $\begin{array}{c}\text { KOAH Grubu } \\
\text { Ort } \pm \text { SS } \\
\text { (Min }- \text { Maks) }\end{array}$ & $\begin{array}{c}\text { KONTROL Grubu } \\
\text { Ort } \pm \text { SS } \\
\text { (Min }- \text { Maks) }\end{array}$ & $\mathbf{t}$ & $\mathbf{p}$ \\
\hline L1-L4 t Skoru & $\begin{array}{c}-0,65 \pm 1,00 \\
(-2,8-1,5)\end{array}$ & $\begin{array}{c}-0,02 \pm 1,25 \\
(-2,8-2,7)\end{array}$ & 1,474 & 0,145 \\
\hline L1-L4 z Skoru & $\begin{array}{c}-0,02 \pm 1,25 \\
(-2,0-2,9)\end{array}$ & $\begin{array}{c}0,36 \pm 1,12 \\
(-2,0-2,3)\end{array}$ & 1,417 & 0,161 \\
\hline $\begin{array}{l}\text { Femur Boynu t } \\
\text { Skoru }\end{array}$ & $\begin{array}{c}-1,19 \pm 0,92 \\
(-3,0-1,7)\end{array}$ & $\begin{array}{c}-1,01 \pm 0,84 \\
(-3,0-0,8)\end{array}$ & 0,869 & 0,388 \\
\hline $\begin{array}{l}\text { Femur Boynu z } \\
\text { Skoru }\end{array}$ & $\begin{array}{c}-0,42 \pm 1,09 \\
(-3,1-2,7)\end{array}$ & $\begin{array}{c}-0,25 \pm 0,75 \\
(-2,1-0,8)\end{array}$ & 0,761 & 0,449 \\
\hline
\end{tabular}

Kisaltmalar: Ort: Ortalama Değer, SS: Standart Sapma, Min: Minimum, Maks: Maksimum, p: Yanılma Olasılı̆̆ı t: İki Ortalama Arasındaki Farkın Önemlilik Testi Değeri.

\subsection{Değerlendirme Parametrelerinin Etki Büyüklüklerinin}

\section{Karşılaştırılması}

Çalışmamızda uyguladığımız test ve anketlerin etki büyüklerini araştırmak için Cohen d etki büyüklüğü hesaplandı. Etki büyüklüklülerine göre kıyaslama yapıldığında HAQ etki büyüklüğü 6,212 ile ilk sırada, SF-36 Genel Sağlık Durumu Kısmı -3,343 ile ikinci sırada, FVC solunum parametresi -3,245 ile üçüncü sırada, $\mathrm{FEV}_{1}-2,826$ ile dördüncü sırada ve SF-36 Ağr1 Parametresi beşinci sırada gözlemlenmektedir. Değerlendirmeler genel olarak karşılaştırıldığında Yaşam Kalitesi Ölçekleri ve Solunum Fonksiyon Testlerinin etki büyüklükleri diğer parametrelere göre daha fazladır. 


\section{TARTIŞMA}

KOAH'lı hastalar için klinikte sıklıkla kullanılan değerlendirme parametrelerine ek olarak kas kuvveti ve kemik mineral yoğunluğu gibi kas-iskelet sistemine ait diğer parametreleri bir bütün olarak değerlendirmeyi amaçlayan bu çalışmaya, stabil durumdaki $40 \mathrm{KOAH}$ tanılı bireyden oluşan hasta grubu ile benzer özelliklere sahip (yaş, cinsiyet dağılımı) 35 bireyden oluşan kontrol grubu dahil edilmiştir. $\mathrm{Bu}$ çalışmada KOAH hastalarının solunum fonksiyonları, egzersiz kapasitesi, kas kuvveti, yaşam kalitesi, anksiyete ve depresyon düzeyi gibi parametreler kontrollü olarak incelenmiştir. Çalışmanın sonucunda KOAH tanılı hastaların KOAH olmayan bireylere göre solunum fonksiyonları, egzersiz kapasiteleri ve kas kuvvet değerlerinin azalmış olduğu; ağrı, anksiyete ve depresyon düzeylerinin artmış olduğu bulunmuştur. Buna karşılık kemik mineral yoğunluğu açısından gruplar arasında herhangi bir farka rastlanmamıştır.

\section{Demografik Özellikler}

Hastaların değerlendirmelerinde ilk olarak hastanın sosyodemografik özelliklerini (yaş, gelir düzeyi, yaşadığı bölge, komorbid durumlar, medeni durumu gibi) kaydedilmiştir. Çalışmamıza 42’si (\% 56) erkek ve 33’ü (\% 44) kadın olmak üzere yaş ortalaması $61,40 \pm 5,21$ olan (yaş aralığı 49 ile 69) toplam 75 kişi alınmış; hasta ve kontrol grubundaki bireylerin ortalama yaşları arasında herhangi bir farka rastlanmamıştır. Çalışmamızdaki hasta gruplarının ve kontrol grubunun benzer yaşlarda ve cinsiyet dağılımında olması, çalışma sonuçlarımızın güvenilirliğini artırması bakımından önemlidir. Çiçek ve Akbayrak (2004) tarafından KOAH'lı hastalarda yapılan benzer bir çalışmada da çalışma ve kontrol grubundaki hastaların yaş ve diğer sosyodemografik verileri arasında istatistiksel olarak önemli fark olmadığı belirlenmiştir. Bu verilerin bizim çalışma verilerimizle paralel yönde olduğu görülmektedir (84).

Obez kişilerde, yağ dokusu gögüs duvarında, diyafragma ve karında birikerek solunum mekaniğini değiştirir. Bunun sonucunda mekanik olarak sıkışan akciğer hacmi ve hava akışı azalır (85). Çalışmamızdaki KOAH'lı hastaların toplum ortalamasına yakın VKİ'ye sahip olduğu ve gruplar arasında anlamlı bir fark olmadığı bulunmuştur. 


\section{Sigara}

KOAH hastalığının gelişimine neden olan en önemli faktörlerden birisi, sigara içmedir. KOAH gelişiminde, sigaranın yol açtığı olumsuz etkiler kadar, sigaranın miktarı da önemlidir. KOAH'lı hastalarda sigara içiminin sürdürülmesi, akut alevlenmeye neden olan en önemli dördüncü etkendir. Sigara içme süresi ve miktarı arttıkça, KOAH'ın görülme sıklığı da artar. Sigarayı bırakma, bireylerde KOAH gelişme riskini ve ilerlemesini azaltır (86). Demirci Üçsular ve ark.'nın yaptığı bir çalışmada, KOAH'lı olguların sigara içme özellikleri araştırılmış ve sigara içen olguların sigarayı bırakmasının ve tedavi konusundaki eğitimin sağlanmasının, hastalığın morbidite ve mortalitesinin azalmasında yarar sağlayacağı belirtilmiştir (87). Çalışmamızdaki KOAH grubunda $(n=40)$ aktif sigara kullanan hiçbir hasta yok iken, KOAH olmayan gruptaki 35 hastanın 15 i $(\% 42,9)$ halen sigara içmekte olduğu görülmüştür. Ancak 40 bireyden oluşan KOAH grubunda geçmişte sigara içen 26 hastanın ( $\%$ 65) daha önceden ortalama 30,17 $\pm 8,88$ (12-42 yıl) süre ile günde ortalama $20,38 \pm 12,15$ tane sigara içtikleri ve 7,12 $\pm 5,13$ y1l önce sigaray 1 bıraktıkları bulunmuştur. Kontrol Grubunda geçmişinde sigara öyküsü olan bireyler dahil sigara içen 24 bireyin 16,16 \pm 7,20 yıl süre ile (2-32 yıl arası) günde 14,33 $\pm 8,94$ tane sigara içtiği ortaya çıkmıştır. Kontrol Grubunda 9 birey sigarayı 4,55 \pm 3,2 yıl önce bırakmıştır. Yapılan istatiksel analizin sonunda sigara içme yılının KOAH Grubunda daha uzun olduğu ve sigarayı daha erken biraktıkları tespit edilmiştir.

\section{Ağrı}

KOAH'lı hastaların günlük yaşam aktivitelerini ve yaşam kalitesini önemli ölçüde etkileyen faktörlerden birisi de ağrıdır. Çalışmamızda KOAH hastalarındaki ağrı düzeyinin, benzer yaş ve cinsiyetteki kontrol grubuna göre belirgin olarak arttığ bulunmuştur. Borge ve ark.'nın (2011) yaptıkları bir çalışmada da bizim sonucumuza benzer olarak KOAH'lı hastalarda kontrol grubuna göre ağrının önemli ölçüde arttığı ve hastaların \%72'sinde ağrı olduğu bildirilmiştirn(88). Bensten ve ark.'nın çalışmalarında da KOAH'lı hasta grubunda görülen ağrı oranının (\%45), kontrol 
grubunda görülen ağrı oranınan (\%34) göre anlamlı düzeyde yüksek olduğu bulunmuştur (89).

HajGhanbari ve ark.'nın 2012'de yayınladıkları bir çalışmaya göre KOAH'lı hastalar sağlıklı yetişkinlere kıyasla 2,5 kat daha fazla ağrı çekmekte ayrıca günlük aktivitelerde bu oran 3,7'ye kadar çıkabilmektedir (90). Bu farkın ortaya çıkmasındaki muhtemel etiyolojiler: sistemik inflamasyon, ağrıya ve dispneye karşı santral adaptasyonlar ve özellikle hiperekspanse durumundaki göğüs duvarından ötürü değişen kas-iskelet biyomekaniğidir. KOAH'lı hastalarda, hastalığın sistematik inflamatuvar doğasından kaynaklı kronik ve nöropatik ağrılar görülebilir. KOAH hastalarının uzun süre devam eden dispne ve ağrıları nedeniyle de ağrı algıları farklı olabilir; çünkü hem ağrı, hem de dispne hissi beyindeki ortak alanlarda haritalanmıştır. Sensoriyal ve affektif özelliklerinden ötürü uzun süre devam eden dispne de beyinde özellikle sensitizasyondan sonra ağrının algılanmasıyla ilgili bazı kalıcı değişiklilere neden olur. Ağrıyı etkilemesi muhtemel bir başka faktör de hiperekspanse ve rijid olan göğüs duvarı mekaniğidir. Bu şekilde adapte olan göğüs duvarı, torasik vertebraları hiperekstansiyonda tutmaya zorlayıp eklem hareket açıklığının azalmasına ve torasik ağrıya neden olmaktadır. Göğüs duvarının bu mekanik dezavantajı diyafragma ve interkostal kasların aşırı kullanımı ile sonuçlanır. Aynı zamanda fiziksel aktivitenin azalması ve bununla birlikte görülen kondüsyon kaybı da zamanla ağrının artmasına neden olmaktadır (91).

Literatürdeki KOAH çalışmalarında ağrının biyo-psiko-sosyo-kültürel boyutlarına yeterince önem verilmediği görülmektedir. Çalışmamızda korku-kaçınma inanışları anketi gibi ağrının psikolojik ve sosyal boyutlarını sorgulayan anketlere de yer verilmek istendiği halde, mevcut değerlendirme parametrelerimizin fazlalığı nedeniyle katılımcılar onay vermemişlerdir. $\mathrm{Bu}$ nedenle, ileride yapılacak araştırmalarda ağrının bu yönlerini de inceleyen daha kapsamlı çalışmalara ihtiyaç duyulmaktadir.

KOAH'lı hastalarda boyun ve göğ̈̈s ağrısının diğer vücut kısımlarına göre daha fazla hissedildiği bildirilmiştir. Bunun da sebebinin primer ve aksesuar solunum kaslarının bu bölgelerde bulunmasıyla ilgili olabileceğinden düşünülmektedir. Ancak HajGhanbari ve ark.'nın 2013 yılında yaptıkları bir çalışmada, bilinen bu ağrı tablosundan farklı olarak hastaların \%35'inde özellikle yürüme sırasında baldır ağrısı 
şikâyeti olduğunu bildirmişlerdir. Fakat bunun sebebinin KOAH'lı hastalara sıklıkla reçete edilen bazı ilaçların yan etkisinden olabileceği yorumunda da bulunmuşlardır (92). Bizim çalışmamızda hastalardaki ağrı değerlendirmesi bölgesel ağrı yerine, istirahat sırasında ve aktiviteden sonra yapılmış; KOAH'lı hasta grubunda ağrının hem istirahatte, hem de aktiviteden sonra KOAH olmayanlara göre anlamlı düzeyde artmış olduğu görülmüştür. Çalışmamızda her ne kadar HajGhanbari ve ark.'nın yaptığı gibi hastalardaki bölgesel ağrılar sorgulanmamış olsa da, bu çalışmanın sonuçlarını bir anlamda destekler nitelikte hastalarımızdaki ağrı düzeyinin aktiviteden sonra (6DYT sonrasında) daha fazla olduğu ve KOAH olmayan hastalar ile yapılan karşılaştırmada ağrı düzeyinin özellikle aktivite sonrası daha belirgin düzeyde artmış olduğu görülmüştür. Hastalarımızın istirahatteki ağrı düzeyleri VAS'

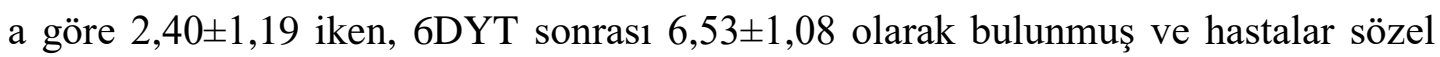
olarak yürüyüşten sonra en çok baldır bölgesindeki ağrıdan şikayetçi olmuşlardır. $\mathrm{Bu}$ da yürüyüş sırasında en çok kullanılan kas gruplarından biri olan Gastrosoleus kas grubunda (baldır kasları) aktivite sonrası ağrıda artış olduğunu düşündürmektedir. Ancak çalışmamızda bölgesel ağrıya yönelik özel bir sorgulama veya değerlendirme yapılmadığı için hastalardaki oranları belirlemek ve bu konuda daha detaylı yorum yapmak mümkün değildir. Ancak diğer çalışmacıların da belirtmiş olduğu gibi (93) KOAH’lı hastalarımızda aktiviteden sonra görülen ağrının nedeni, hastaların kullandığı bazı spesifik ilaçlardan veya kondüsyon kaybından kaynaklanmış olabilir; ancak bu konuda bir sorgulama veya bir istatistiksel analiz yapmadığımız için bu konuda kesin bir karara varmak doğru değildir.

\section{Postür}

KOAH tanılı hastaların postürünün, benzer yaş grubundaki sağlıklı kişilere göre oldukça bozulmuş olduğu görülmüş ve postür bozukluğunu artıran risk faktörlerinin ileri yaş, kas güçsüzlüğü, fiziksel inaktivite, oksijen desteği ihtiyacı ve hareket kısıtlılığı olduğu bildirilmiştir (94). Morais ve ark.'nın yaptıkları çalışmada (2016), KOAH'lı hastalarda postür ve üst gövde mobilitesinin solunum fonksiyonlarına olan etkisini incelemişlerdir. $15 \mathrm{KOAH}$ 'lı ve $15 \mathrm{KOAH}$ olmayan bireylerden oluşan çalışmada pulmoner fonksiyon $\mathrm{FEV}_{1}$ ve $\mathrm{FVC}$ solunum testleriyle 
değerlendirilirken, baş, gövde ve omuz dizilimi dijital fotoğraflama yapılarak incelenmiştir. Sonuç olarak KOAH'lı hastalarda maksimum protraksiyondaki omuz ile birlikte baş postürünün önde olduğu, torasik kifozun görüldüğü ve omuz fleksiyonunun azalmış olduğu bildirilmiş ve torasik kifozun FVC ile ilişkili olduğu saptanmıştır (95). KOAH'lı hastalarda postüral kontrol bileşenlerinin tümünde bir azalma mevcuttur. Bu durum biomekanik ve vertikal yöndeki postüral kısitl1l1klar, değişen duruş özellikleri, yürüyüş veya diğer aktiviteler sırasındaki postüral stabilite ve oryantasyon için gerekli duyusal girdi eksikliği veya yanlış girdi ile ilişkildir. KOAH'lı hastalarda görülen postür değişiklikleri literatürde rapor edilse de bunların kapsamlı olarak incelenmesi ve klinik açıdan önemi pek vurgulanmamıştır. Bu konuda yapılmış en kapsamlı sistematik derleme Lee ve ark.'nın yaptığı çalışma olarak görünmektedir. Lee ve ark. literatürdeki obstrüktif solunum problemi olan hastalarda postürel değerlendirme yapan araştırmaları incelemiş ve bunu raporlamıştır. İncelenen bu çalışmalarda postürel değerlendirme yöntemlerinin belirli bir standartta olmadığı ve bu değerlendirmelerde çok çeşitli yöntemlerin kullanıldığ1 bildirilmiş; KOAH'lı hastalarda en s1k görülen postürün, elevasyonda omuz protraksiyonu olduğu ortaya konulmuştur (96). Yaptığımız çalışmada bireylerin postürü değerlendirilirken diğer çalışmacıların yaptığı gibi postürografi veya digital fotoğraflama yöntemi kullanma olanağımızın olmaması ve bu parametrenin çalışmamızın hipotezinde önemli bir yer teşkil etmemesi nedeniyle hastaların postürü sadece tanımlayıcı bir özellik olarak ele alınmış ve bunun için gözlemsel bir analiz yapılmıştır. Yaptığımız gözlemsel değerlendirmenin sonucunda, KOAH'lı hastalarda özellikle kifoz ve lordoz gibi spinal deformitelerin daha fazla olduğu bulunmuştur. Değerlendirmenin sonucunda KOAH Grubunda 19'unda (\%47,5), Kontrol Grubunda 11 'inde $(\% 31,4)$ kifoz bulguları saptanmıştır. KOAH Grubunda 5 $(\% 12,5)$ ve Kontrol Grubunda 2 kişide $(\% 5,7)$ skolyoz, KOAH Grubunda 12 kişide (\%30) ve Kontrol Grubunda 9 kişide $(\% 25,4)$ lomber lordoz gözlemlenmiştir. KOAH Grubundaki 40 kişinin 12'sinde (\%30) ve 35 kişilik Kontrol Grubunun 5'inde $(\% 14,3)$ çökük göğüs fenotipi gözlemlenmiştir. KOAH Grubundan 14 kişi (\%35) ve Kontrol Grubundan 6 kişi (\% 17,1) üzerinde fiçı gögüs fenotipi saptanmıştır. Tüm bu sonuçlarımız literatür bilgisi ile uyumlu bulunmuştur. Ancak, bu sonuçların daha iyi yorumlanabilmesi için gözleme dayalı postür değerlendirmesinden çok, objektif 
veriler sağlayan daha kompleks değerlendirmelere ve postürografi gibi daha hassas ölçüm cihazlarına ihtiyaç vardır.

\section{Solunum Fonksiyonları}

Solunum fonksiyon testleri, klinik belirti ve semptomlara ek olarak KOAH tanısı koymada klinikte kullanılan objektif ölçüm yöntemlerinin en önemlilerinden birisidir. $\mathrm{Bu}$ testte obstrüksiyon bulgusu büyük önem taşımaktadır ve aynı zamanda hastalığın şiddetinin belirlenmesinde ve tedavinin planlanmasında da oldukça etkilidir. KOAH'lı hastalara uygulanan solunum fonksiyon testleri spirometrik ölçüm yöntemleri ile yapılır ve bu testlerde saptanabilen en önemli değişiklik, ekspiratuvar akımlardaki veya hacimlerdeki kısıtlanma olarak bilinir. $\mathrm{FEV} 1 / \mathrm{FVC}<\% 70$ oran obstrüksiyonu tanımlamada kullanılır. Bir saniyedeki zorlu ekspiratuvar volüm $\left(\mathrm{FEV}_{1}\right)$ değeri, KOAH hastalığının alevlenme dönemlerindeki hastaneye yatış kriterlerinde, kötü prognoz faktörü olarak kabul edilir. Yoshimi ve ark.'nın yapmış olduğu çalışmada 31 KOAH'lı hastanın sadece 1 tanesi evre I (FEV $1 \geq 80 \%)$, 4hastanın evre II $(50 \% \leq \mathrm{FEV} \geq 80 \%), 18$ hastanın evre III $(30 \% \leq \mathrm{FEV} \geq 50 \%), 8$ hastanın ise evre IV $\left(\mathrm{FEV}_{1}<30 \%\right)$ olarak tespit edilmiştir.(97) Kargın ve ark.'nın 2015 yılında 104 KOAH'lı hasta ile yapmış olduğu çalışmada ise değerlendirmelerinde hastaların FEV1 değerlerinin ortalaması \% 89,8 \pm 18,4, $\mathrm{FEV}_{1} / \mathrm{FVC}$ değerleri ortalamas1 \% 79,7 $\pm 8,6, \mathrm{FEF}_{25-75}$ değerleri ortalamas1 \% 77,5 \pm 27,1 olarak bulunmuştur (98). Durutürk'ün yapmış olduğu çalışmasında hastaların ilk tanımlayıc1 değerlendirmesinde FEV1 değerlerinin ortalaması \% 57,43 $\pm 14,55$, $\mathrm{FEV}_{1} / \mathrm{FVC}$ değerleri ortalamas1 \% 45,75 $\pm 10,73, \mathrm{FEF}_{25-75}$ değerleri \% 17,12 $\pm 6,17$ olarak tesbit edilmiştir (99). Bizim çalışmamızda $\mathrm{KOAH}$ grubunun $\mathrm{FEV}_{1} / \mathrm{FVC}$

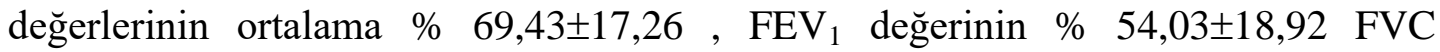

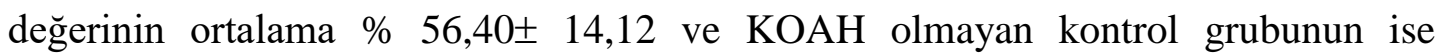
ortalama $\mathrm{FEV}_{1} / \mathrm{FVC}$ değerlerinin \% 103,31 $\pm 6,92$, ortalama $\mathrm{FEV}_{1}$ değerinin \%

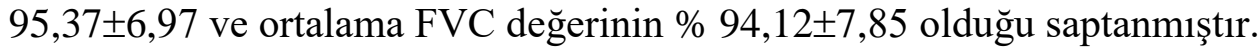

Diffüzyon Testi (DLCO), obstrüktif tip akciğer hastalıkların ayırıcı tanısında önemli bir yere sahiptir ve KOAH'ın erken tanısında oldukça önemlidir (100). Diffüzyon kapasitesi, KOAH tanılı olanlarda ve sigara içenlerde anatomik amfizem derecesinin iyi bir göstergesidir. Fakat KOAH'lı hastalarda $\mathrm{FEV}_{1}$ değerinin aksine, 
DLCO değeri ile dispnenin derecesi arasında iyi bir ilişki görülmemektedir (101).Egzersiz eğitimi pulmoner kan akımını artırarak DLCO'da artışa neden olur. Akkoca ve ark.'1 yaptıkları bir çalışmada, 32 KOAH hastasının ve 28 sağlıklı bireyin DLCO testini değerlendirmişler ve KOAH grubunda DLCO'nun azaldığını, diğer grupta ise normal kaldığını gözlemlemişlerdir (102). Morrison ve ark. akciğer elastisitesindeki ve DLCO deki azalmanın, KOAH'ta iki önemli fonksiyon bozukluğu olduğunu ifade etmişlerdir (103). Knudson ve ark. $1174 \mathrm{KOAH}$ tanılı hasta üzerinde yaptıkları bir çalışmada yine DLCO'nun KOAH hastalığı ile ilişkili olarak azaldığını göstermişlerdir (104). Bizim çalışmamızda da DLCO’nun literatür ile uyumlu olarak KOAH Grubundaki hastalarda KOAH olmayan bireylere göre çok daha düşük olduğu bulunmuştur.

KOAH hastalarında KOAH'ın kliniğini daha sağlıklı bir şekilde değerlendirmek ve KOAH tanısını destekleyebilmek için DLCO testinin de solunum fonksiyon testleri ile birlikte yapılması gerekmektedir. Bizim sonuçlarımız da bir anlamda bu sonuçları desteklemektedir.

\section{Egzersiz Kapasitesi}

Egzersiz kapasitesi ve fiziksel uygunluk düzeyi genel sağlık tanımının en önemli parçasıdır. Sağlıklı olmak, kişinin fiziksel, mental ve sosyal açıdan iyi olması hali olup bireyin yaşam kalitesinin devamlılığını sağlamaktadır. Koruyucu fizyoterapinin bir parçası olan fiziksel aktiviteler, bireyin sağlığını geliştiren ve devamlılığını sağlayan, hastalıklara ve yorgunluğa karşı direnci artıran, yaşam kalitesini koruyan hareketlerin toplamı olarak bilinmektedir. Fiziksel uygunluk düzeyinin değerlendirilmesi, çeşitli hastalıklarda ve sağlıklı kişilerde, kişisel ihtiyaçlara uygun eğitim programlarının belirlenmesinde yol göstericidir. Sağlıkla ilgili fiziksel uygunluğu belirlemek için; vücut kompozisyonu, kardiyorespiratuvar endurans, kas-iskelet sistemi (esneklik, kassal kuvvet ve endurans) ve motor uygunluğun (çeviklik ve denge) değerlendirilmesi gerekir (105). KOAH'lı hastaların aynı cins ve yaştaki sağlıklı bireyler ile karşılaştırıldığında, fonksiyonel kapasiteleri ve maksimal egzersiz performanslarında azalma olduğu görülmektedir. Akciğer mekanizmasında bozulma, solunum ve alt ekstremite kaslarının kas kuvvetinde azalma, kardiyolojik fonksiyon bozukluğu, dengesiz beslenme, kondüsyon kaybı ve 
psikolojik bozukluklar nedeni ile KOAH hastalarının egzersiz ve fonksiyonel kapasiteleri olumsuz yönde etkilenir (106).

Singer ve ark. KOAH tanılı 828 hastada yaptığı bir çalışmada, azalmış solunum ve alt ekstremite kas kuvvetinin 6 Dakikalık Yürüyüş Testi (6DYT) ve alt ekstremite fonksiyonları üzerine olan etkisini değerlendirmişlerdir. Çalışmanın sonucunda her iki cinsiyette de azalmış alt ekstremite ve solunum kas kuvvetinin, KOAH hastalarında azalmış egzersiz kapasitesi ile yakından ilişkili olduğu ve bu parametrelere bağlı olarak KOAH hastalarında egzersiz kapasitesinin önemli derecede azaldığı bildirilmiştir (107).

6 Dakikalık Yürüme Testi (6 DTY), fonksiyonel egzersiz kapasitesini değerlendirmek için literatürde sıklıkla kullanılan bir testtir. 6 DYT klinik ortamda uygulanması basit ve uygulayan tarafından anlaşılması kolay bir testtir. Güvenilirliği ve geçerliliği olan bu testin 14,0 m ile 30,5 m'ye kadar olan farkının klinik olarak önemli bir fark olduğu Bohannon ve ark.'nın (2016) yaptığı bir sistematik derleme ile gösterilmiştir (108). Literatüre uygun olarak bizim çalışmamızda da KOAH hastaları için 6DYT uygulanmıştır. Hastaların 6 DYT sonuçları KOAH Grubunda ortalama 369,13 $\pm 64,91$ metre olarak bulunurken, KOAH olmayan bireylerden

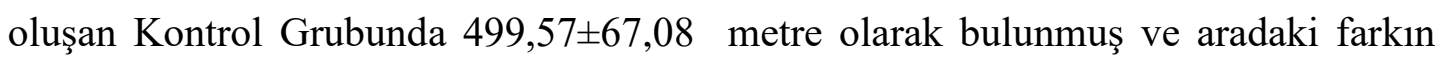
istatistiksel olarak anlamlı olduğu sonucuna varılmıştır. Bu sonuca göre KOAH'lı hastalarda egzersiz kapasitesinin KOAH olmayan bireylere göre belirgin olarak azalmış olduğu ortaya konulmuştur.

Fujimoto ve ark.'nın (2018) son yayınladıkları çalışmada 6DYT mesafesi ile DLCO ve FEV1 parametrelerini kullanarak hesaplanan Desaturasyon-Mesafe Oranı'nın kullanılabilirliği araştırılmıştır (109). Çalışmanın sonucunda KOAH hastalarında Desaturasyon-Mesafe Oranının pulmoner hipertansiyon ve amfizemi belirlemek için iyi bir indeks olduğunu belirtmişlerdir.Biz de çalışmamızda 6DYT, FEV1 ve DLCO oranlarını değerlendirdiğimiz için bu çalışmada bahsedilen oranın hesaplamak mümkündür; ancak pulmoner hipertansiyonu belirlemek bizim çalışma kapsamımız dışında kaldığ 1 için böyle bir hesaplama yapılmamıştır. KOAH ile ilgili çalışmalarda klinik olarak uygulanması zor olsa da birkaç test ve parametrenin birlikte uygulanmasının bir avantajı da bunun gibi benzer oran ve indekslerin hesaplanabilmesi olanağıdır. Her ne kadar çalışmamızda bu oran hesaplanmamış olsa 
da ileride yapılması muhtemel diğer çalışmalarda bu oranın değerlendirme parametrelerine eklenebileceği öngörülmektedir.

\section{Kas kuvveti}

KOAH'lı hastalarda görülen iskelet kaslarındaki zayıflık, özellikle alt ekstremite kaslarındaki zayıflık, bu hastalarda egzersiz kapasitesini azaltan en önemli sistemik etkilerindendir (110). Yapılan birçok çalışma ile KOAH'lı hastalarda iskelet kaslarının zaman içinde morfolojik yapısının bozulduğu ve fonksiyonunun azaldığı gösterilmiştir (111). KOAH'lı hastaların bacak kaslarındaki kuvvet kaybı ile düşük egzersiz kapasitesi arasındaki ilişkinin patofizyolojisi literatürde farklı şekillerde açıklanmıştır. Bu açıklamalardan biri, KOAH'lı hastaların iskelet kas liflerinin Tip I'den Tip II'ye dönüştüğü, kas lif demeti başına düşen mitokondriyal yoğunluğun ve kılcal damar yoğunluğunun azaldığı ve bunların sonucunda kas zayıflığının ortaya çıktığı yolundadır (112). KOAH'lı hastalarda C-reaktif protein (CRP) ve interlökin-8, interlökin-6 ve tümör nekroz faktörü $(\mathrm{TNF}-\alpha)$ gibi proinflamatuvar sitokinler daha yüksek oranlarda görülür (113). TNF- $\alpha$, kas kontraktibilitesini ve mitokondriyal biyogeneziyi inhibe eder ve apoptoz yoluyla kas yıkımını arttırır (114). Bir başka açıklama ise, azalmış fiziksel aktivite nedeniyle gelişen kas atrofisidir. Yaş, malnütrisyon, hipoksi, reaktif oksijen türleri ve oksidatif enzim düzeylerindeki azalma gibi diğer faktörler de KOAH'ı hastalardaki kas zayıflı̆̆ı ile ilişkili risk faktörleri olarak açıklanır (115).

Ekspiratuvar kas gruplarının en önemlilerinden biri olan abdominal kasların, kuadriseps kasına benzer kas lifi tipi dağılımı vardır. Bununla birlikte, KOAH'lı hastalarda, özelikle kronik dönemde kuadriseps kası yetersiz kullanılırken, abdominal kaslar öksürme sırasında ve egzersiz sırasında kasılır ve hatta dinlenme durumunda da aktif olabilir (116). Bundan dolayı, kuadriseps kas zayıflığı ile birlikte abdominal kaslarda da zayıflığın görülmesi, KOAH’ta sistemik faktörlerin önemli olduğunu gösterir ve ciddi KOAH tanılı hastalarda abdominal kasların kuvvetindeki azalma belirgin hale gelir (117).

Çalışmamızda, KOAH Grubu ve KOAH hastası olmayan kontrol hastalarının kuadriseps, hamstringler, gastrokinemius, abdominal ve sirt ekstansör 
kas grupları değerlendirilerek birbirleri ile karşılaştırılmıştır. Yapılan değerlendirmenin sonucunda, KOAH Grubunda abdominaller ve gastroknemius kas grubunun kas kuvvetinin KOAH olmayan gruba göre anlamlı düzeyde azalmış olduğu bulunmuş; buna karşıllk kuadriseps, hamstringler ve sırt ekstansörlerinin kuvvetlerinin birbirine benzer olduğu bulunmuştur. KOAH Grubunda abdominal kaslardaki kuvvet kaybının gastroknemius kas grubundaki kuvvet kaybından daha anlamlı olduğu görülmüştür. Literatürdeki bazı çalışmaların aksine KOAH Grubundaki hastalarda quadriceps kasında herhangi bir azalmanın olmaması, ayrıca hastalarımızda abdominal kaslarda zayıflık görüldüğü halde onunla ilişkili olarak quadriseps kas kuvvetinde herhangi bir azalmanın olmaması, bizim hasta grubumuzun GOLD sınflandırmasına göre evresinin düşük olmasından (GOLD a göre evre I ve II) kaynaklanabilir. Ayrıca KOAH grubumuzdaki hastalarımızın yaş ortalamasının (49-69 yaş arası; ortalama $61,63 \pm 6,02$ yıl) literatürdeki birçok çalışmadaki hastaların yaş ortalamasına göre daha düşük olması da buna bir neden olarak gösterilebilir. Literatürdeki çalışmalarda yer alan KOAH hastalarının büyük bir çoğunluğunun yaş ortalamasının bizim hastalarımızın yaş ortalamasından daha büyük olması ve ileri yaş ortalamasına sahip olan bu hastalarda quadrisepste görülen kas zayıflığının yaşlanmaya bağlı olarak ortaya çıkan fiziksel inaktivite ve özellikle quadrisepte görülen sarkopeniden kaynaklanabilir. Bizim hasta grubumuzun yaş ortalamasının küçük ve aktivite düzeyinin yüksek olması, özellikle yürümede aktif olarak kullanılan quadriseps kasında böyle bir kuvvet kaybına yol açmamış olabilir.

\section{Anksiyete ve Depresyon}

KOAH tanılı hastalar, azalmış egzersiz kapasitesi, artmış dispne hissi ve komorbid hastalıkları nedeni ile çoğunlukla kendilerini kısıtlı bir alana bağımlı hissederler ve hastalık ilerledikçe dispne ataklarıyla ilişkili olarak anksiyete ve depresyona olan eğilimleri de artar. Özellikle ileri dönem KOAH'lı hastalarda depresyon ve anksiyete prevalansı oldukça yüksektir. Bazen, hafif düzey KOAH'lı hastalarda bile anksiyete ve depresyon prevalansı yüksek olabilir. Bu nedenle birçok hasta ailelerine çok fazla bağımlı hale gelir; çaresizlik duyguları artar, benlik saygılarında azalma olur ve sonuç olarak zaman içinde daha kaygılı ve depresif 
olurlar. Zaman içinde bu şekilde ilerleme gösteren anksiyete ve depresyon belirtileri, KOAH'lı hastalarda daha olumsuz sonuçlar doğurur ve inaktivite oranı hızla yükselir. Çoğu hastada toplumsal izolasyona da neden olur $(118,119)$. Yapılan bir çalışmada, depresif özellikteki KOAH tanılı hastaların, depresif olmayan hastalara oranla hastalığın alevlenme riskinin yaklaşık üç kat daha fazla olduğu gösterilmiştir (120). Yapılan başka bir çalışmada ise, KOAH tanılı hastalarda depresif belirtilerin varlığı ile hastalığın alevlenme oranlarının artışı arasında güçlü bir ilişki olduğu tespit edilmiştir (121).

$\mathrm{Bu}$ nedenle bu hastalarda anksiyete ve depresyonunun azaltılması veya önlenmesi oldukça önemlidir. $\mathrm{Bu}$ durum hem hastalığın semptomlarını ve alevlenmesini azaltır; hem de fiziksel inaktivite ve buna bağlı olarak gelişen komorbiteyi önler. Yapılan çalışmaların bir kısmında pulmoner rehabilitasyon ile artan sosyal etkileşimin de hastalar üzerinde oldukça etkili olduğu gösterilmiştir (122). Casaburi ve ZuWallack (2009) yaptıkları bir çalışmada, KOAH'lı hastalarda sosyal etkileşimin nefes darlığı hissinde desensitizasyon sağlayarak dispne hissini azalttığını göstermişlerdir (50).

Anksiyete, KOAH ta görülen en önemli semptomlardan biri olup, yüksek mortalite ve morbitideye sahiptir. Literatürdeki çalışmaların büyük çoğunluğunda anksiyete ve depresyon genellikle 'Anksiyeteniz var mı?" gibi basit anket sorularıyla değerlendirilmekte, hastaların büyük çoğunluğu bu tarz sorulara objektif cevap vermemekte ve sonuçlar da iyi yorumlanamamaktadır. Yaptığımız çalışmada anksiyeteyi ölçmek için bu gibi anketlere göre daha kompleks ve daha detaylı sorulardan oluşan bir anket kullanılmak istenmiş ve çalışmamızdaki bireylerin anksiyete ve depresyon düzeyleri birçok çalışmada kullanıldığı gibi $(123,124)$ Beck Depresyon ve Beck Anksiyete Skalaları ile değerlendirilmiştir. KOAH Grubundaki bireylerin Kontrol grubundaki bireylere göre daha yüksek anksiyete ve depresyon puanına sahip olduğu bulunmuştur. $\mathrm{Bu}$ sonuçlar, literatürde bu konu ile ilgili çalışmaların sonuçlarına çıkmıştır (125).

Beck Depresyon ve Beck Anksiyete Skalalarının etki büyüklüğü bakımından tüm diğer değerlendirme ölçeklerimiz ile karşılaştırıldığında bu ölçeklerin, diğerlerine göre daha az etki büyüklüğ̈ olduğu saptanmıştır. Bu sonuca göre klinik pratikte birçok parametrenin bir arada değerlendirilmesinin zor olduğu bu hasta 
grubu için BECK Depresyon ve BECK Anksiyete ölçeklerinin önceliği yoktur ve diğer ölçeklerden sonra gelir. $\mathrm{Bu}$ hasta grubu için öncelikli olarak pulmoner fonksiyon testleri, CAT veya Saint George parameterleri,6 DYT uygulandiktan sonra BECK Depresyon ve BECK Anksiyete Skalası uygulanabilir. Ancak KOAH'lı hastalara Beck Anksiyete ve BECK Depresyon Anketleri uygulamasının, hastaların anksiyete ve depresyon durumunu değerlendirerek, aktivite kısıtlaması ve sosyal izolasyon nedeniyle hastalarda ortaya çıkabilecek kısır döngünün erken dönemde saptanıp ona göre önlenmesi açısından oldukça önemlidir.

\section{Yaşam Kalitesi}

Dispne hissi ile başa çıkamama, kas kitlesinde azalma, fiziksel aktivite eksikliği ve günlük yaşam aktivitelerinde limitlenme ve sonucunda yaşam kalitesinde bozulma, KOAH'lı hastaların yaşamını olumsuz yönde etkileyen en önemli sorunlardandır. KOAH hastalarında yaşam kalitesinin düzeyi, hastalığın ciddiyeti ve bulguların şiddeti ile, hastaların alevlenme sonucu hastaneye ve sağlık kurumlarına başvurma sıklıkları ile ve hastalıkları hakkında sahip oldukları bilgi düzeyleri ile yakından ilişkilidir.

Mahler ve Mackiowiak'a göre, SF-36 Yaşam Kalite Ölçeği, KOAH'lı hastalarda yaşam kalitesini ölçmek için değerli bir araçtır (126). Diğer taraftan, KOAH'lı hastaların SF-36 skorlarının rehabilitasyonun başlangıcında genel popülasyondan oldukça düşük değerlerde olması nedeni ile bu ölçeğin bu hastaların rehabilitasyondan gördükleri yararı değerlendirmede yeterli veya yeterince hassas olmadığı da tartışılmaktadır (127, 128). Literatürde, SF-36'nın KOAH'lı hastaların yaşam kalitesini değerlendirmek için yeterli bir ölçek olmadığı tartışması nedeniyle, çalışmamızda yaşam kalitesini değerlendiren başka bir ölçek olan HAQ kullanılmıştır ve bu ölçek ile hastaların yaşam kalitesi değerlendirildiğinde de benzer sonuçlar alınmıştır.

İnal'ın, KOAH'lı hastalar üzerinde yaşam kalitesini değerlendirdiği bir çalışmada, KOAH'lı hastaların kontrol grubundaki sağlıklı bireylere göre Nottingham Health Profili (NHP), cinsel hayat, enerji seviyesi, ilgiler ve hobiler alt boyutlarının daha fazla etkilenmiş olduğu bulunmuştur. Ayrıca, diğer bir çalışmada 
genel yaşam kalitesi olan SF-36, fiziksel fonksiyon, genel sağlık ve canlılık alt boyutlarının kontrol grubuna göre daha fazla etkilenmiş olduğu saptanmıştır (129).

Çalışmamızda KOAH'lı hastalar, KOAH hastası olmayan Kontrol grubuyla karşılaştırıldığında SF-36'nın tüm parametrelerinde KOAH Grubu aleyhine belirgin farklar bulunmuştur. HAQ ile yapılan değerlendirmede de benzer sonuçlar alınmış ve KOAH'lı hastaların yaşam kalitesinin Kontrol Grubuna göre oldukça düşük olduğu bulunmuştur. Yaptığımız etki büyüklüğü testleri sonucunda SF-36 ve HAQ yaşam kalitesi ölçeklerinin etki büyüklüklerinin diğer tüm parametreler için kullanılan ölçeklere göre daha fazla olduğu bulunmuştur. Bu sonuçlarımıza bakarak klinikte veya araştırmalarda yapılan $\mathrm{KOAH}$ değerlendirmesinde yaşam kalitesinin mutlaka değerlendirilmesi gerektiği düşünülmüştür.

\section{Kemik mineral yoğunluğu}

KOAH'lı hastalarda, hastalığın patogenezine bağlı kronik sistemik inflamasyon sonucu ortak risk faktörlerinden bağımsız olarak gelişen ve zaman içinde şiddetlerinin arttığı komorbiditeler bulunmaktadır. Bunlardan birisi de osteoporozdur (130). Düşük kemik mineral yoğunluğu veya osteoporoz, KOAH' da sıklıkla görülen bir durumdur. Bu nedenle de KOAH'da incelenmesi gereken bir diğer önemli parametre de kemik mineral yoğunluğudur. KOAH'lı hastalarda, kronik sistemik inflamasyon, uzun süreli glukokortikostroid kullanımı, azalmış fiziksel aktivite ve buna bağlı olarak kemik üzerine yeteri kadar yük binmemesi, osteoporoz için en önemli risk faktörleri olarak bilinir (131, 132). Sin ve ark.'a göre, KOAH'taki diğer faktörlerden bağımsız olarak hava akışındaki obstrüksiyonun varlığı da düşük kemik mineral yoğunluğu ile ilişkilidir (133).

KOAH'ın şiddeti ile kemik mineral yoğunluğu arasında yakın bir ilişki vardır; hastalığın evresi arttıkça kemik mineral yoğunluğu da anlamlı düzeyde azalır ve hastalarda görülen osteopeni ve osteoporoz insidans1 $\operatorname{artar}(131,132)$. 9502 katılımcı ile yapılan bir çalışmada, ağır derecede KOAH'ı olan kadın hastaların \%33'ünde osteoporoz, hafif ve orta derece KOAH'1 olan kadın hastaların hemen hepsinde osteopeni, ağır derece KOAH'1 olan erkek hastaların ise \%11'inde osteoporoz, \%60'ında osteopeni saptanmıştır. Ayrıca bu değerlerin beklenen sonuçlardan 3 kat daha fazla olduğu tespit edilmiştir (133). KOAH'ta osteoporoza 
bağlı olarak gelişen vertebra, kalça ve distal radius kırıkları, hastalar için önemli morbidite ve mortalite nedenleri arasındadır. Vertebra kırıkları kifoza, kronik sırt ağrılarına ve bunlarla ilişkili olarak vital kapasitenin azalmasına neden olur. $\mathrm{Bu}$ nedenle osteoporozun önlenmesi veya tedavisi, KOAH hastaları için önem teşkil eder (130, 134). Yapılan bir çalışmada, yüksek glukokortikosteroid kullanımının vertebralarda görülen kompresyon kırığı insidansını artırdığı bulunmuştur (132). KOAH'lı hastalarda torasik vertebra kırıkları arttıkça vital kapasitede ve total akciğer kapasitesinde ciddi oranda azalma olduğu saptanmıştır (134). Osteoporoz ile ilişkili kifozun da hastaların torakal kafes hareketliliğinde kısıtlanmalara ve inspiratuvar kasların fonksiyonlarında azalmalara neden olduğu, bunun da $\mathrm{FEV}_{1}$ ve FVC'deki kayıplara yol açtığı bulunmuştur (135).

Vrieze ve arkadaşları (2007) GOLD evre IV olan hastalarda \%75 oranında düşük mineral yoğunluğu görülebileceğini bildirmişlerdir. Aynı çalışmada VKİ azaldıkça kemik mineral yoğunluğunda anlamlı bir artış olduğu da raporlanmıştır. Yaptığımız bu çalışmada, KOAH grubumuzda genelde GOLD sınıflamasına göre evre I ve II olan stabil durumdaki hastalar yer aldığı için, Kontrol Grubu ile karşılaştırıldığında kemik mineral yoğunluğu bakımından anlamlı bir fark bulunmamıştır (136). KOAH Grubunda Kontrol grubu ile olan bu benzerlik, KOAH grubundaki hastaların fiziksel aktivite düzeylerinin çok düşük olmamasından ve VKİ ortalamalarının da istenen miktarda yüksek olmasından kaynaklanmış olabilir. Buna karşılık özellikle GOLD’a göre evre IV KOAH hastalarında VKİnin düşük olması, kemik mineral yoğunluğunda düşük t-skoru için bir risk faktörü olabilir ve kemik mineral yoğunluğu açısından kapsamlı bir değerlendirmeyi gerektirebilir. 2013 yılında Denisson ve arkadaşlarının yaptığı bir kohort çalışmada 60-72 yaşları arasındaki 985 kişide solunum fonksiyonlarının ( $\left.\mathrm{FEV}_{1}, \mathrm{FVC}, \mathrm{FEV}_{1} / \mathrm{FVC}\right)$ kemik mineral yoğunluğu ile olan ilişskisi incelenmiş ve aralarında herhangi bir ilişkinin olmadığı bildirilmiştir (137). Bizim çalışmamız kohort çalışma niteliğinde bir çalışma olmadığı ve her ne kadar aynı parametreler değerlendirilmiş olsa da, parametreler arasında böyle ilişkinin varlığına bakılmış olmadığı için, bu çalışmacıların sonuçları ile herhangi bir karşılaştırma yapma olanağımız yoktur.

Literatüre bakarak KOAH hastalarının hepsinin düşük kemik mineral yoğunluğuna sahip olduğu yorumunu yapmak doğru olmayabilir; çünkü bizim 
sonuçlarımız bu fikri doğrulamamaktadır. Ancak hastalarımızın GOLD’ a göre evre I ve II olmaları nedeniyle fiziksel olarak daha aktif olmalarının, olumlu anlamda daha yüksek VKİye sahip olmaları ve daha düşük doz ilaç kullanmalarının sonuçlarımıza olumlu etkisi olabilir. İleride yapılacak çalışmalarda GOLD evre III veya evre IV KOAH hastalarında daha farklı sonuçlar alınabileceği ve bu hastalarda kemik mineral yoğunluğu araştırılırken GOLD sınıflamasına göre KOAH evrelerinin gözönünde bulundurulmasının önemli olduğu düşünülmektedir.

Sonuçlarımıza göre, GOLD evre I ve II olan stabil KOAH hastalarında pulmoner fonksiyonlar, egzersiz kapasitesi, yaşam kalitesi ve kas kuvveti azalırken, ağrı seviyesi, anksiyete ve depresyon düzeyleri artar. Postür ve kemik mineral yoğunluğunda ise hiçbir değişiklik olmaz. Ancak, bu sonuçlar, hastalığın evresi düşük ve yaşı ortalaması düşük (49-69 yaş arası; ortalama 61,63 $\pm 6,02$ yıl) olan $\mathrm{KOAH}$ hastaları için geçerli olduğu için, ileride yapılacak çalışmalarla evresi daha yüksek olan ve ileri yaş KOAH hastaları için ayrı bir profil ortaya konulmalıdır. Böylelikle KOAH hastalarının hem değerlendirmesinde, hem de tıbbi tedavisi ve rehabilitasyonunda standart bir protokol yerine, beklenen profil doğrultusunda bir uygulama prensibi geliştirilmiş olur. $\mathrm{Bu}$ prensipler, KOAH hastalarının bireysel özelliklerinin daha sistematik hale getirilmesini sağlayarak, klinisyenler için daha pratik ve etkili bir değerlendirme ve tedavi programı planlanmasına, araştırmacılar için çalışma planının daha iyi yapılmasına ve daha hassas sonuçların alınmasına olanak sağlar.

Yapmış olduğumuz çalışmamıza göre;

Hipotez -1: KOAH'lı hastalarda solunum fonksiyonları ve egzersiz kapasitesi KOAH olmayan bireylere göre azalmıştır. KOAH'lı hastalarda bu parametrelerin azalması hipotezimizi doğrulamaktadır.

Hipotez -2: KOAH'lı hastalarda yaşam kalitesi ve psikososyal durum KOAH olmayan bireylerden farklıdır. KOAH'lı hastalarda yaşam kalitesi azalırken, anksiyete ve depresyon düzeylerinde artma görülmüştür ve hipotezimiz doğrulanmaktadır.

Hipotez-3: KOAH'lı hastalarda kemik mineral yoğunluğu, ağrı ve kas kuvveti $\mathrm{KOAH}$ olmayan bireylere göre farklıdır. KOAH'lı hastalarda kemik mineral yoğunluğunda fark bulunmazken, ağrı düzeylerinde artış görülmüş ve kas 
kuvvetlerinde ise azalma tesbit edilmiştir. Tüm bu sonuçlar hipotezimizin kısmen gerçekleştiğini doğrulamaktadır.

\section{Çalışmanın Limitasyonları}

1-Çalışmamızda GOLD evre I ve II KOAH tanılı hastalar dahil edildiği için ileri evrelerde görülebilecek bazı semptom ve bulgular ortaya konulamamış olabilir.

2-Kas kuvveti ölçümünde ve postür analizinde daha hassas ölçüm yapılabilmesi için gerekli olan hassas ölçüm cihazları elimizde olmadığı için kullanılamamıştır.

3-Çalışmamızda yapmış olduğumuz hasta grubumuzun ileri yaş KOAH grubunu temsil etmemiş olması çalışmamızın limitasyonlarından birisidir. 


\section{SONUÇLAR VE ÖNERILER}

$\mathrm{Bu}$ çalışma yaşları 49-69 arasında değişen $40 \mathrm{KOAH}$ tanılı hasta ile yaşları 53-69 değişen $35 \mathrm{KOAH}$ tanısı olmayan bireyin ağrı, postür, kemik mineral yoğunluğu, kas kuvveti, solunum fonksiyon kapasitesi, yaşam kalitesi, egzersiz kapasitesi ve anksiyete faktörlerin bir arada incelenmesi amacıyla yapılmıştır.

1. Çalışmamızdaki KOAH tanılı bireylerin KOAH olmayan bireylere oranla solunum fonksiyonları, kas kuvvetleri, egzersiz kapasitesi, yaşam kaliteleri belirgin derecede azalmış, ağrı, anksiyete ve depresyon düzeyleri ise artmıştır. Tüm bu sonuçlar literatür ile benzer özellik göstermiştir.

2. KOAH tanılı hastalarda anksiyete ve depresyonun fazla olduğu ve bunların hastaların yaşam kalitesini doğrudan etkilediği görülmüştür.

3. KOAH'lı hastalar ile kontrol grubundaki bireylerin kemik mineral yoğunluğunda fark bulunmaması, yapmış olduğumuz çalışmada daha çok stabil durumdaki GOLD evre I ve II hastalarından oluştuğu ve bireylerin fiziksel aktivite düzeylerinin çok düşük olmamasından ve VKİ ortalamalarının da istenen miktarda yüksek olmasından kaynaklanmış olabileceği düşünülmüştür.

4. Çalışmamızda uyguladığımız test ve anketlerin etki büyüklüğü değerlendirildiğinde, SF-36 ve HAQ parametrelerinin etki büyüklüklerinin diğer tüm parametrelerden daha fazla olduğu, KOAH hastalarında yaşam kalitesi değerlendirilmesinin önemini göstermiştir. HAQ’a göre yaşam kalitesinin etki büyüklügüünün en yüksek çıkmış olması mümkünse bu değerlendirmenin öncelikli olarak tercih edilebileceğini göstermiştir.

5. Yapmış olduğumuz çalışmamızda sadece stabil durumda olan GOLD evre I ve II tanılı KOAH'lı hastaları dahil ettik belki tüm evreleri dahil edip yapmış olduğumuz değerlendirmeler ile GOLD'a göre ileri evreler ile erken evreleri kendi aralarında karşılaştırma olanağına sahip olabilirdik.

6. Kemik mineral yoğunluğu bakımından almış olduğumuz erken evre hastalarımıza ileri evre KOAH hastaları dahil edilip bu parametrenin değişimi gözlenebilir ve yapmış olduğumuz diğer parametrelerimiz ile kolerasyon durumlarını inceleyebilirdik. 
7. Çalışmamızda yapmış olduğumuz değerlendirmeler doğrultusunda uyguladığımız parametrelerin öncelik sıraları göz önünde bulundurularak, hastalara iyi planlanmış bir rehabilitasyon protokolünün etkinliği değerlendirilebilinir. 


\section{KAYNAKLAR}

1. 2017 REPORT Global Initiative for Chronic Obstructive Lung (GOLD) [Internet]. 2017[Erişim Tarihi:14 Eylül 2018]. Erişim adresi: http://www.goldcopd.com

2. Chacon PFS, Schon CF, Furtado VHLA, Signoretti GLAM, Oliveira JPP, Ribeiro AG, et al. Support and rehabilitation of patients with pulmonary expansion deficit by using game therapy. Annu Int.Conf.2016:5632-5.

3. Coventry PA, Bower P, Keyworth C, Kenning C, Knopp J, Garrett C, et al. The effect of complex interventions on depression and anxiety in chronic obstructive pulmonary disease: systematic review and meta-analysis. PLoS One. 2013;8(4):e60532.

4. Leidy NK, Murray LT, Monz BU, Nelsen L, Goldman M, Jones PW, et al. Measuring respiratory symptoms of COPD: performance of the EXACTRespiratory Symptoms Tool (E-RS) in three clinical trials. Respir Res. 2014 Oct;15:124.

5. Liu X-L, Tan J-Y, Wang T, Zhang Q, Zhang M, Yao L-Q, et al. Effectiveness of home-based pulmonary rehabilitation for patients with chronic obstructive pulmonary disease: a meta-analysis of randomized controlled trials. Rehabil Nurs. 2014;39(1):36-59.

6. Weldam SWM, Lammers J-WJ, Decates RL, Schuurmans MJ. Daily activities and health-related quality of life in patients with chronic obstructive pulmonary disease: psychological determinants: a cross-sectional study. Health Qual Life Outcomes. 2013 Nov;11:190.

7. Sciriha A, Lungaro-Mifsud S, Scerri J, Magro R, Camilleri L, Montefort S. Health status of COPD patients undergoing pulmonary rehabilitation: A comparative responsiveness of the CAT and SGRQ. Chron Respir Dis. 2017;14(4):352-9.

8. Pitta F, Troosters T, Probst VS, Langer D, Decramer M, Gosselink R. Are patients with COPD more active after pulmonary rehabilitation? Chest. 2008 Aug;134(2):273-80.

9. Yavuz Selim İntepe, Eylem Yıldırım, Bayram Metin, Seyhan Karaçavuş, Özlem Balbaloğlu. The Evaluation of Bone Mineral Density in Patients with Chronic Obstructive Pulmonary Disease. Bozok Medilcal J. 2015;1(1):20-6.

10. Man WD-C, Kemp P, Moxham J, Polkey MI. Exercise and muscle dysfunction in COPD: implications for pulmonary rehabilitation. Clin Sci (Lond). 2009;117(8):281-91.

11. Celli B, Goldstein R, Knobil K. Future perspectives in COPD. 2005Dec;p.418.

12. Larson T, Gudavalli R, Prater D, Sutton S. Critical analysis of common canister programs: a review of cross-functional considerations and health system economics. Curr Med Res Opin. 2015 Apr;31(4):853-60. 
13. Islam SMS, Purnat TD, Phuong NTA, Mwingira U, Schacht K, Froschl G. Non-communicable diseases (NCDs) in developing countries: a symposium report. Vol. 10, Globalization and health. England; 2014. p. 81.

14. Kart L, Akkoyunlu M.E, Bayram M, Yakar F, Kutbay Özçelik H, Karaköse F, et al. COPD: an underdiagnosed disease at hospital environment. Wien Klin Wochenschr. 2014 Feb;126(3-4):73-8.

15. Ghattas C, Dai A, Gemmel DJ, Awad MH. Over diagnosis of chronic obstructive pulmonary disease in an underserved patient population. Int $\mathrm{J}$ Chron Obstruct Pulmon Dis. 2013;8:545-9.

16. Abul Y,Özlü T,Türkiyede KOAH epidemiyolojisi,Karadeniz Teknik Üniversitesi Göğüs hastalıkları Anabilim Dalı,Trabzon 2013;1(1):7

17. Arslan Z, Ilgazli A, Etiler N, Hamzaoglu O. Prevalence of chronic obstructive pulmonary disease in kocaeli: an industrialised city in Turkey. Balkan Med J. 2013 Dec;30(4):387-93.

18. Perez-Padilla R, Fernandez R, Lopez Varela MV, Montes de Oca M, Muino A, Talamo C, et al. Airflow obstruction in never smokers in five Latin American cities: the PLATINO study. Arch Med Res. 2012 Feb;43(2):159-65.

20. Guirguis-Blake JM, Senger CA, Webber EM, Mularski R, Whitlock EP. Screening for Chronic Obstructive Pulmonary Disease: A Systematic Evidence Review for the U.S. Preventive Services Task Force. Rockville (MD); 2016.

21. Kalfopoulos M, Wetmore K, K ElMallah M. Pathophysiology of Alpha-1 Antitrypsin Lung Disease. Methods Mol Biol. 2017;1639:9-19.

22. Karl FM, Holle R, Bals R, Greulich T, Jorres RA, Karch A, et al. Costs and health-related quality of life in Alpha-1-Antitrypsin Deficient COPD patients. Respir Res. 2017 Apr;18(1):60.

23. Rajkumar P, Pattabi K, Vadivoo S, Bhome A, Brashier B, Bhattacharya P, et al. A cross-sectional study on prevalence of chronic obstructive pulmonary disease (COPD) in India: rationale and methods. BMJ Open. 2017 May;7(5):e015211.

24. Edwards SC, Fairbrother SE, Scowcroft A, Chiu G, Ternouth A, Lipworth BJ. The burden of chronic obstructive pulmonary disease associated with maintenance monotherapy in the UK. Int J Chron Obstruct Pulmon Dis. 2016;11:2851-8.

25. Murray CJL, Atkinson C, Bhalla K, Birbeck G, Burstein R, Chou D, et al. The state of US health, 1990-2010: burden of diseases, injuries, and risk factors. JAMA. 2013 Aug;310(6):591-608.

26. Murray CJL, Richards MA, Newton JN, Fenton KA, Anderson HR, Atkinson $\mathrm{C}$, et al. UK health performance: findings of the Global Burden of Disease Study 2010. Lancet (London, England). 2013 Mar;381(9871):997-1020.

27. Qaseem A, Wilt TJ ve diğerleri. (2011). Diagnosis and Management of Stable Chronic Obstructive Pulmonary Disease: A Clinical Practice Guideline Update from the American College of Physicians, American College of Chest 
Physicians, American Thoracic Society and European Respiratory Society. Ann Intern Med, 155, 179- 191

28. Grone O, Garcia-Barbero M. Integrated care: a position paper of the WHO European Office for Integrated Health Care Services. Int J Integr Care. 2001; $1:$ e21.

29. Rajput C. Chronic Obstructive Pulmonary Disease Meta Genome-Wide Association Studies. New Insights into the Genetics of Chronic Obstructive Pulmonary Disease. Am J Respir Cell Mol Biol. 2017 Jul;57(1):1-2.

30. Wain L V, Shrine N, Artigas MS, Erzurumluoglu AM, Noyvert B, BossiniCastillo L, et al. Genome-wide association analyses for lung function and chronic obstructive pulmonary disease identify new loci and potential druggable targets. Nat Genet. 2017 Mar;49(3):416-25.

31. Milanzi EB, Brunekreef B, Koppelman GH, Wijga AH, van Rossem L, Vonk JM, et al. Lifetime secondhand smoke exposure and childhood and adolescent asthma: findings from the PIAMA cohort. Environ Health. 2017 Feb;16(1):14.

32. Fontana L, Lee S-J, Capitanelli I, Re A, Maniscalco M, Mauriello MC, et al. Chronic Obstructive Pulmonary Disease in Farmers: A Systematic Review. J Occup Environ Med. 2017 Aug;59(8):775-88.

33. Sadhra S, Kurmi OP, Sadhra SS, Lam KBH, Ayres JG. Occupational COPD and job exposure matrices: a systematic review and meta-analysis. Int J Chron Obstruct Pulmon Dis. 2017;12:725-34.

34. Mannino, D.M.,Buist, A.S. (2007) Global burden of COPD: risk factors, prevalence, and future trends. Lancet, 370 (9589), 765-773.

35. Mannino, D.M.,Davis, K.J. (2006). Lung function decline and outcomes in an elderly population. Thorax, 61 (6), 472-477.

36. Leung JM, Tiew PY, Mac Aogain M, Budden KF, Yong VFL, Thomas SS, et al. The role of acute and chronic respiratory colonization and infections in the pathogenesis of COPD. Respirology. 2017 May;22(4):634-50.

37. Grigsby M, Siddharthan T, Chowdhury MA, Siddiquee A, Rubinstein A, Sobrino E, et al. Socioeconomic status and COPD among low- and middleincome countries. Int J Chron Obstruct Pulmon Dis. 2016;11:2497-507.

38. Mahmood T, Singh RK, Kant S, Shukla A Das, Chandra A, Srivastava RK. Prevalence and etiological profile of chronic obstructive pulmonary disease in nonsmokers. Lung India. 2017;34(2):122-6.

39. Park HJ, Byun MK, Kim HJ, Kim JY, Kim Y-I, Yoo K-H, et al. Dietary vitamin $\mathrm{C}$ intake protects against COPD: the Korea National Health and Nutrition Examination Survey in 2012. Int J Chron Obstruct Pulmon Dis. 2016;11:2721-8.

40. Mekary RA. A higher overall diet quality is inversely associated with the risk of chronic obstructive pulmonary disease (COPD) in men and women. Evid Based Med. 2016 Feb;21(1):36. 
41. Casanova C, Oca MM De, Mendez RA, Plata VP, Cabral HJ, Ph D. The BodyMass Index, Airflow Obstruction, Dyspnea, and Exercise Capacity Index in Chronic Obstructive Pulmonary Disease. 2004;1005-12.

42. Başyiğit İ. (2010). KOAH Patogenezi ve Fizyopatolojisi. Toraks Cerrahisi Bülteni. 1(2), 114- 118.

43. 2014 Global Initiative for Chronic Obstructive Lung (GOLD), ). the Global Strategy For The Diagnosis, Management and Prevention of Chronic Obstructive Pulmonary Disease. [Internet]. 2014[Erişim Tarihi:10 Eylül 2018]. [Erişim adresi: http://www.goldcopd.com]

44. Raherison, C.,Girodet, P.O. (2009). Epidemiology of COPD. European Respiratory Review; 18 (114), 213-221.

45. MacNee, Pathogenesis of chronic obstructive pulmonary disease. Proceedings of the American Thoracic Society; 2 (4), 258-266

46. Eapen MS, Myers S, Walters EH, Sohal SS. Airway inflammation in chronic obstructive pulmonary disease (COPD): a true paradox. Expert Rev Respir Med. 2017 Aug;1-13.

47. DeTurk W.E., Cahalin, L.P. (2004). Cardiovasculary and Pulmonary Physical Therapy. Newyork::GTS

48. MacNee, W. (2005). Pathogenesis of chronic obstructive pulmonary disease. Proceedings of the American Thoracic Society, 2 (4), 258-266; discussion 290-251.

49. Antoniu SA. Descriptors of dyspnea in obstructive lung diseases. Vol. 5, Multidisciplinary Respiratory Medicine. 2010. p. 216-9.

50. Casaburi R, ZuWallack R. Pulmonary rehabilitation for management of chronic obstructive pulmonary disease. N Engl J Med. 2009 Mar;360(13):1329-35.

51. Gülbay BE, Saryal SB, Acican T. (2003). Patogenez ve inflamasyon. Kronik Obstruktif Akciğer Hastalı̆̆ . Ankara Bilimsel Tıp Yayınevi. B2, 21- 33

52. Spruit MA, Singh SJ, Garvey C, ZuWallack R, Nici L, Rochester C, et al. An official American Thoracic Society/European Respiratory Society statement: key concepts and advances in pulmonary rehabilitation. Am J Respir Crit Care Med. 2013 Oct;188(8):e13-

53. Laveneziana P. Physiology and consequences of lung hyperinflation in COPD. 2006;61-7.

54. Ho C-F, Maa S-H. [Application of the 6-Minute Walking Test and Shuttle Walking Test in the Exercise Tests of Patients With COPD]. Hu Li Za Zhi. 2016 Aug;63(4):107-15.

55. Miller MR, Hankinson J, Brusasco V, Burgos F, Casaburi R, Coates A, et al. Standardisation of spirometry. Eur Respir J. 2005 Aug;26(2):319-38.

56. Pellegrino R, Viegi G, Brusasco V, Crapo RO, Burgos F, Casaburi R, et al. Interpretative strategies for lung function tests. Eur Respir J. 2005 Nov;26(5):948-68. 
57. Fahndrich S, Bernhard N, Lepper PM, Vogelmeier C, Seibert M, Wagenpfeil $\mathrm{S}$, et al. Exacerbations and duration of smoking abstinence are associated with the annual loss of FEV1 in individuals with PiZZ alpha-1-antitrypsin deficiency. Respir Med. 2017 Aug;129:8-15.

58. Kim K, Byun M, Lee W, Cynn H, Kwon O, Yi C. Effects of breathing maneuver and sitting posture on muscle activity in inspiratory accessory muscles in patients with chronic obstructive pulmonary disease. Vol. 7, Multidisciplinary Respiratory Medicine. 2012. p. 9.

59. Gonçalves MA, Francisco DS, Medeiros CS, Brüggemann AK,Mazo GZ, Paulin E, Postural alignment of patients with chronic obstruktive pulmonary disease,Fisioter.mov.vol.30, no.3 Crutiba,2017

60. Mador MJ, Kufel TJ. Reproducibility of visual analog scale measurements of dyspnea in patients with chronic obstructive pulmonary disease. Am Rev Respir Dis. 1992 Jul;146(1):82-7.

61. Nishiyama O, Taniguchi H, Kondoh Y, Nishimura K, Suzuki R, Takagi K, et al. The effectiveness of the visual analogue scale 8 in measuring health-related quality of life for COPD patients. Respir Med. 2000 Dec;94(12):1192-9.

62. Dajczman E,Wardini R,Kasymjanova G, Prefontaine D, Baltzan MA,Wolkove N,Six minute walk distance is a predictor of survival in patients with chronic obstructive pulmonary disease undergoing pulmonary rehabilitation,Can Respir J.,2015Jul;22(4) 225-229.

63. Spruit MA, Burtin C, Boever P, Langer D,Vogiatzis I, Wouters E ve ark. COPD and exercise:does it make a difference?,Breathe She.,2016 Jun;12(2)38-49.

64. Gökbel H, Kronik akciğer hastalığı ve egzersiz,Selçuk Üniversitesi Tıp Fakültesi,Konya,Türkiye Klinikleri J Sport Med-Special Topics.2015;1(2):159.

65. Kim K, Byun M, Lee W, Cynn H, Kwon O, Yi C. Effects of breathing maneuver and sitting posture on muscle activity in inspiratory accessory muscles in patients with chronic obstructive pulmonary disease. Vol. 7, Multidisciplinary Respiratory Medicine. 2012. p. 9.

66. Bestall JC, Paul EA, Garrod R.(1999).Usefulness of Medical Research Council (MRC) dyspnea scale as a measure of disability in patients with chronic obstructive pulmonary disease.Thorax,54;581-86.

67. Mahler DA, Criner GJ. (2007). Assesment tools for chronic obstructive pulmonary disease. Do never metrics allow for disease modification? Proc Am Thorac Soc, 4, 507- 511.

68. Dodd JW, Hogg L, Nolan J, Jefford H, Grant A, Lord VM, et al. The COPD assessment test (CAT): Response to pulmonary rehabilitation. A multicentre, prospective study. Thorax. 2011;66(5):425-9.

69. Yorgancıoğlu A, Polatlı M, Aydemir Ö, Demirci N, Kırkıl G, Naycıatış G. Ve ark.,KOAH değerlendirme testinin Türkçe geçerlilik ve güvenilirliği. Tuberk Toraks. 2012;60(4):314-20. 
70. Jones PW, Quirk FH, Baveystock CM. (1991). The St Georges Respiratory Questionnaire. Respiratory medicine, 85(B), 25- 31

71. Polatlı M, Yorgancıoğlu A, Aydemir Ö, Yılmaz Demirci N, Kırkıl G, Atış Nayc1 S, et al. Validity and reliability of Turkish version of St. George's respiratory questionnaire. Tuberk Toraks [Internet]. Erişim tarihi: 2013;61(2):81-7.

72. Celli B, Tetzlaff K, Criner G, Polkey MI, Sciurba F, Casaburi R, et al. The 6Minute-Walk Distance Test as a Chronic Obstructive Pulmonary Disease Stratification Tool. Insights from the COPD Biomarker Qualification Consortium. Am J Respir Crit Care Med [Internet]. 2016 Dec 15;194(12):1483-93.

73. Press VG, Cifu AS, White SR. Screening for Chronic Obstructive Pulmonary Disease. JAMA. 2017 Nov;318(17):1702-3.

74. Yang IA, Brown JL, George J, Jenkins S, McDonald CF, McDonald VM, et al. COPD-X Australian and New Zealand guidelines for the diagnosis and management of chronic obstructive pulmonary disease: 2017 update. Med J Aust. 2017 Nov;207(10):436-42.

75. Ho C-F, Maa S-H. [Application of the 6-Minute Walking Test and Shuttle Walking Test in the Exercise Tests of Patients With COPD]. Hu Li Za Zhi. 2016 Aug;63(4):107-15.

76. RW L, EG M. Certain aspects of infantile paralysis: With a description of a method of muscle testing. J Am Med Assoc [Internet]. 1916 Mar 4;LXVI(10):729-33. Available from: http://dx.doi.org/10.1001/jama.1916.02580360031009

77. Bandy WBNRW. Chapter 1. Measurement of Range of Motion and Muscle Length: Background, History and Basic Principles. In: Joint Range of Motion and Muscle Length Testing. 1st ed. 9781416068709; 2002.

78. Tobergte DR, Curtis S. Beck'S Depression Inventory. J Chem Inf Model. 2013;53(9):1689-99.

79. Tuğlu C.,Aktürk Z, Dağdeviren N, Türe M, Birinci Basamak İçin Beck Depresyon Tarama Ölçeğinin Türçe Çeviriminin Geçerlik Güvenirliği. Türk Aile Hekimliği Dergisi. 2005;9(3):117-22.

80. Seber G, Dilbaz N, Kaptanoğlu C, Tekin D. Umutsuzluk Ölçeği: Geçerlilik ve Güvenirliği. Kriz Derg [Internet]. 1998;1(3):139-42.

81. Kucukdeveci AA, Sahin H, Ataman S, Griffiths B, Tennant A. Issues in crosscultural validity: example from the adaptation, reliability, and validity testing of a Turkish version of the Stanford Health Assessment Questionnaire. Arthritis Rheum. 2004 Feb;51(1):14-9.

82. R. P. Sağlık araştırmalarında yeni bir kavram: Yaşam kalitesi, bir yaşam kalitesi ölçeğinin kronik hastalarda geçerlik ve güvenirliğinin sinanması. Hemşirelik Bülteni. 1995;(9):85-95. 
83. Polatlı, M., Yorgancıŏglu, A., Aydemir, Ö., Yılmaz Demirci, N., Kırk1l, G., Atış Naycı, S. ve diğerleri. (2013) St. George solunum anketinin Türkçe geçerlilik ve güvenilirliği. Tüberküloz ve Toraks, 61 (2), 81-87

84. Sutcu Cicek H, Akbayrak N. Kronik Obstrüktif Akciğer Hastaligi olan bireylerde solunum egzersizlerinin kan gazlari ve solunum fonksiyon testlerine etkisi. Gulhane Med J. 2004;46(1):1-9.

85. Faria AG, Ribeiro MAGO, Marson FAL, Schivinski CIS, Severino SD, Ribeiro JD, et al. Effect of exercise test on pulmonary function of obese adolescents. J Pediatr (Rio J). 2014;90(3):242-9.

86. American Thoracic Society. (1981). Medical Section of the American Lung Association. Pulmonary rehabilitation. Am Rev Respir Dis, 124(5), 663- 666

87. Demirci Üçsular F,Kayık Demir A,Polat G,Güçlü S.KOAH'lı olguların sigara içme özellikleri.2004;(3):107-112

88. Borge CR,Wahl AK,Moum T, Pain and quality of life with chronic obstructive pulmonary disease, Heart Lung.2011;40(3) 90-101.

89. Bentsen S, Christine M, Bruce AC, Vivi LC, Anne H, Holm A,Rustoen T, Distinct pain profiles in patients with chronic obstructive pulmonary disease, Int J Chron Obstruct Pulmon.Dis. 2018;13:801-811.

90. HajGhanbari B, Holsti L, Road JD, Reid D, Pain in people with chronic obstructive pulmonary disease (COPD).University of British Columbia,Canada. 2012

91. Knight DA, Yang I, Ko FWS, Lim TK. (2012). Year in review 2011: Asthma, COPD and airway biology. Respirology, 17, 563- 572

92. HajGhanbari B,Garland S.J.,Road JD.,Reid W.D,Pain and physical performancein people with COPD,University of Biritish Columbia,Canada 2013

93. Mannino DM, Buist AS. (2007). Global burden of COPD: risk factors, prevalence, and future trends. Lancet. 370, 765- 73

94. Smith MD, Chang AT, Seale HE, Walsh JR, Hodges PW. (2010). Balance is impaired in people with chronic obstructive pulmonary disease. Gait \& Posture, 31, 456- 460

95. Morais N,Cruz J, Marques A,Posture and mobility of the upper body quadrant and pulmonary function in COPD,Braz J Phys Ther.2016; 20 (4):345-354.

96. Lee A, Zabjek K, Goldstein R, Brooks D, Postural abnormalities in people with chronic obstructive pulmonary disease, Europan Respiratory Journal 2016;48:PA1344

97. Yoshimi K, Ueki J, Seyama K, Takizawa M, Yamaguchi S, Kitahara E, et al. Pulmonary rehabilitation program including respiratory conditioning for chronic obstructive pulmonary disease (COPD): Improved hyperinflation and expiratory flow during tidal breathing. Vol. 4, Journal of Thoracic Disease. 2012. p. 259-64.

98. Kargın N, Marakoğlu K, Sigarayı bırakmanın solunum işlevleri üzerine etkisi, 
Selçuk Üniversitesi Tıp Fakültesi Aile Hekimliği Anabilim Dalı,Konya, 2015; 19(3):130-135.

99. Durutürk N,(2013)Kronik Obstrüktif Akciğer Hastalığı Olan Hastalarda Bisiklet Ergometresi İle Kalistenik Egzersiz Eğitiminin Karşılaştırılması,Doktora Yeterlilik Tezi,Hacettepe Üniversitesi,Ankara

100. Bodil Bjoernshave, Jens Korsgaard, Chris Jensen CVN. Participation in pulmonary rehabilitation in routine clinical practice. Clin Respir J. 2011;

101. Corhay J-L, Dang DN, Van Cauwenberge H, Louis R. Pulmonary rehabilitation and COPD: providing patients a good environment for optimizing therapy. Vol. 9, International Journal of Chronic Obstructive Pulmonary Disease. 2014. p. 27-39.

102. Akkoca Ö,Karabıyıkoğlu G, Kronik obstruktif akciğer hastalarında diffüzyon kapasitesinin spesifik diffüzyon katsayısının önemi, Ankara Üniversitesi T1p Fakültesi,Ankara 1996 ; 49 (1): 39-44

103. Morrison NJ, Abboud RT, Ramadan F et al.Comparison of DLCO and pressure-volume curves in detecting emphysema. Am Rev Respir Dis 1989; 139:1179-1187.

104. Knudson RJ, Kaltenbom WT, Knudson DE,et al. The single-breath carbon monoxide diffusing capacity: reference equations derived from a healthy nonsmoking population and effects of hematocrit. Am Rev Respir Dis 1987; 135: 805-811.

105. Troosters T, Gosselink R, Decramer M. (2001). Exercise training in COPD: how to distinguish responders from non-responders. J Cardiopulm Rehabil, $21,10-7$

106. Nici L. (2000). Mechanisim and measures of exercise intolerance in COPD. Clin Chest Med, 21, 693- 704

107. Singer J, Yelin EH, Katz PP, Sanchez G, Iribarren C, Eisner MD, et al. Respiratory and skeletal muscle strength in COPD: Impact on exercise capacity and lower extremity function. J Cardiopulm Rehabil Prev [Internet]. 2011;31(2):111-9.

108. Bohannon RW. Muscle strength: clinical and prognostic value of hand-grip dynamometry. Curr Opin Clin Nutr Metab Care. 2016;18(5):465-470.

109. Fujimoto K, Kitaguchi Y, Kubo K, Honda T. Clinical analysis of chronic obstructive pulmonary disease phenotypes classified using high-resolution computed tomography. Respirology. 2018;11(6):731-740.

110. Lear S, Brozıc A, Myers JN, Ignaszewsk1 A. (1999). Exercise stres testing. Sports Med, 27(5), 285- 312

111. Kim K, Byun M, Lee W, Cynn H, Kwon O, Yi C. Effects of breathing maneuver and sitting posture on muscle activity in inspiratory accessory muscles in patients with chronic obstructive pulmonary disease. Vol. 7, Multidisciplinary Respiratory Medicine. 2012. p. 9.

112. Antonello N, Valentina M, Bruna G, Maura F-B, Banfi P, Cornelius B. 
Comparison Of Effectiveness Of Temporary Positive Expırayory Pressure Versus Oscillatory Positıve Expıratory Pressure In Severe Copd Patients. Clin Respir J. 2017 Jun;

113. Johnson MA, Polgar J, Weightman D, Appleton D. Data on the distribution of fibre types in thirty-six human muscles. An autopsy study. J Neurol Sci. 1973 Jan;18(1):111-29.

114. Fritz M, Fransen E, Broekhuizen R ve diğerleri. (2005). Limp muscle dysfunction in COPD: Effects of muscle wasting and exercise trainig. Med Sci Sport Exerc, 37, 2- 9

115. Beauchamp MK, Hill K, Goldstein RS, Janaudis-Ferreira T, Brooks D. (2009). Impairments in balance discriminate fallers from non-fallers in COPD. Respiratory Medicine, 103, 1885- 91

116. Man WDC, Mustfa N, Nikoletou D, Kaul S, Hart N, Rafferty GF, et al. Effect of salmeterol on respiratory muscle activity during exercise in poorly reversible COPD. Thorax. 2004 Jun;59(6):471-6.

117. Mador MJ, Mogri M, Patel A. Contractile fatigue of the quadriceps muscle predicts improvement in exercise performance after pulmonary rehabilitation. J Cardiopulm Rehabil Prev. 2014;34(1):54-61.

113. Carbo N, Busquets S, van Royen M, Alvarez B, Lopez-Soriano FJ, Argiles JM. TNF-alpha is involved in activating DNA fragmentation in skeletal muscle. Br J Cancer. 2002 Mar;86(6):1012-6.

114. Jobin J, Maltais F, Doyon JF, LeBlanc P, Simard PM, Simard AA, et al. Chronic obstructive pulmonary disease: capillarity and fiber-type characteristics of skeletal muscle. J Cardiopulm Rehabil. 1998;18(6):432-7.

115. Dentener MA, Creutzberg EC, Schols AM, Mantovani A, van't Veer C, Buurman WA, et al. Systemic anti-inflammatory mediators in COPD: increase in soluble interleukin 1 receptor II during treatment of exacerbations. Thorax. 2001 Sep;56(9):721-6.

116. Aniwidyaningsih W, Varraso R, Cano N, Pison C. Impact of nutritional status on body functioning in chronic obstructive pulmonary disease and how to intervene. Curr Opin Clin Nutr Metab Care. 2008 Jul;11(4):435-42.

117. Barnes, P.J., Celli, B.R. (2009) Systemic manifestations and comorbidities of COPD. European Respiratory Journal, 33 (5), 1165-1185.

118. Wittchen HU, Jacobi F, Rehm J, Gustavsson A, Svensson M, Jönsson B, et al. The size and burden of mental disorders and other disorders of the brain in Europe 2010. Eur Neuropsychopharmacol [Internet]. 2011;21(9):655-79. Available

from: http://www.sciencedirect.com/science/article/pii/S0924977X11001726

119. Pumar MI, Gray CR, Walsh JR, Yang IA, Rolls TA, Ward DL. Anxiety and depression-Important psychological comorbidities of COPD. J Thorac Dis. 2014 Nov;6(11):1615-31.

120. Bratas O, Espnes GA, Rannestad T, Walstad R. Pulmonary rehabilitation reduces depression and enhances health-related quality of life in COPD 
patients--especially in patients with mild or moderate disease. Chron Respir Dis. 2010;7(4):229-37.

121. Janssen DJA, Spruit MA, Leue C, Gijsen C, Hameleers H, Schols JMGA, et al. Symptoms of anxiety and depression in COPD patients entering pulmonary rehabilitation. Chron Respir Dis. 2010 Aug;7(3):147-57. 
122. Van Ede L, Yzermans CJ, Brouwer HJ. (1999). Prevalence of depression in patients with chronic obstructive pulmonary disease: A systematic review. Thorax, 54, 688- 92

123. Kim HF, Kunik ME, Molinari VA, Hillman SL, Lalani S, Orengo CA, Petersen NJ, Nahas Z. (2000). Goodnight-White S. Functional impairment in COPD patients: The impact of anxiety and depression. Psychosomatics, 41, 465- 71.

124. Schneider C, Jick SS, Bothner U, et al. COPD and the risk of depression.Chest 2010, 137(4);341-347

125. Goodwin RD,Lavoie KL, Lemeshow AR,et al.Depression,anxiety and copd:The unexamined role of nicotine dependence.Nicotine Tob Res 2012;14:176-183.

126. Mahler DA, Mackowiak JI. Evaluation of the short-form 36-item questionnaire to measure health-related quality of life in patients with COPD. Chest. 1995 Jun;107(6):1585-9.

127. Limsuwat C, McClellan R, Amiri HM, Nugent K. Pulmonary rehabilitation improves only some domains of health-related quality of life measured by the Short Form-36 questionnaire. Vol. 9, Annals of Thoracic Medicine. India; 2014. p. $144-8$.

128. Sousa Pinto JM, Martin-Nogueras AM, Morano MTAP, Macedo TEPM, Arenillas JIC, Troosters T. Chronic obstructive pulmonary disease patients' experience with pulmonary rehabilitation: a systematic review of qualitative research. Chron Respir Dis. 2013 Aug;10(3):141-57.

129. İnal D. (1997). Kronik obstruktif akciğer hastalarında ve sağlıklı kişilerde yaşam kalitesinin değerlendirilmesi. Bilim Uzamanlığ 1 Tezi, Hacettepe Üniversitesi, Ankara

130. Carter JD, Patel S, Sultan FL, Thompson ZJ, Margaux H, Sterre A, et al. The recogni on and treatment of vertebral fractures in males with chronic obstruc ve pulmonary disease. Respir Med. 2008;102(8):1165-72.

131. Ciric Z, Stankovic I, Pejcic T, Ris c L, Rancic M, Radovic M, et al. Osteoporosis in pa ents with chronic obstruc ve pulmonary disease. Med Arh. 2012;66(6):385-387.

132. Jørgensen NR, Schwarz P, Holme I, Henriksen BM, Petersen LJ, Backer V. The prevalence of osteoporosis in pa ents with chronic obstruc ve pulmonary disease: a cross sec onal study. Respir Med. 2007;101(1):177-85.

133. Sin DD, Man JP, Man SF. The risk of osteoporosis in Caucasian men and women with obstructive airways disease. Am JMed 2003; 114:10-14.

134. Leech JA, Dulberg C, Kellie S, Pattee L, Gay J. Relationship of lung function to severity of osteoporosis in women. Am Rev Respir Dis 1990; 141:68-71.

135. Schlaich C, Minne HW, Bruckner T, Wagner G, Gebest HJ, Grunze M, Ziegler R, Leidig- Bruckner G. Reduced pulmonary function in patients with spinal osteoporotic fractures. Osteoporos Int 1998; 8:261-267. 
136. Vrieze A,dE Greef MH,Wijkstra PJ,Wempe JB,Low bone mineral density in COPD patients related to worse lung function,low weight and decreased fatfree mass.Osteoporos Int.2007 Sep;18(9):1197-202.

137. Dennison EM, Dhanwai DK, Shaheen SO, Azagra R, Jameson KA, Sayer AA, ve ark.Is lung function associated with bone mineral density?Results from the hertfordshire cohort study. Arch Osteoporos.2013;8(0):115. 


\section{EKLER}

Ek 1. Modifiye MRC Dispne Skalas1

\section{Ek Tablo 1: Modifiye MRC Dispne Skalası}

Lütfen size en uygun olan kutucuğu işaretleyiniz (Sadece tek kutucuk).

mMRC EVRE 0

mMRC EVRE 1 Düz yolda hızlı yürürken veya hafif bir yokuşu çıkarken nefes darlığı var.

MMRC EVRE 2 Nefes darlığı nedeni ile düz yolda kendi yaşındaki insanlardan daha yavaş yürüyor veya düz yolda kendi hızıyla yürürken nefes almak için durması gerekiyor.

mMRC EVRE 3 Ortalama 100 metre veya birkaç dakika yürüdükten sonra durup nefes alması gerekir.

mMRC EVRE 4 Nefes darlığı nedeni ile ev dışına çıkamıyor veya giyinip soyunurken nefes darlığ 1 oluyor. 
Ek 2. KOAH Değerlendirme Anketi (COPD- Assessement Test=CAT

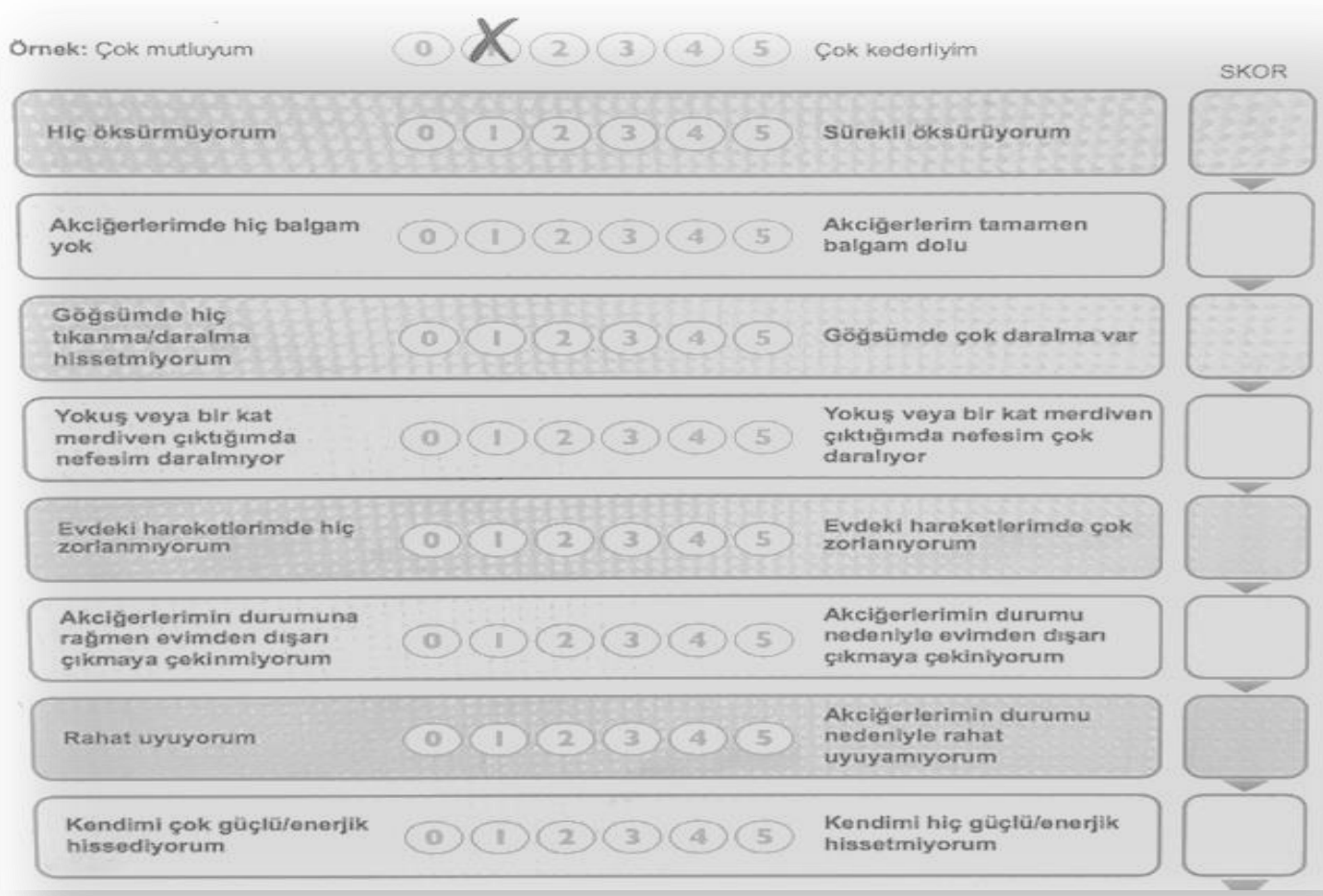


Ek 3. St.George's Respiratory Questionnaire (SGRQ)

SOLUNUM SISTEMİ ANKETI (St. George's Respiratory Questionnaire (SGRQ)

Bu anket, göğüs hastalığınızın size verdiği sıkıntıyı ve yaşamınıza olan etkisini daha iyi anlamanızı sağlamak üzere hazırlanmıştır. Bu anket, doktorların tanılarının yanı sıra, şikayetlerinize sebep olan göğüs hastalığınızı tüm yönleriyle değerlendirmek amacı ile kullanılacaktır.

Lütfen soruları dikkatle okuyunuz. Anlamadığınız her şeyi sorunuz.

Cevap verirken sorular üzerinde çok düşünmeyiniz.

Adınız-Soyadınız:

Tarih:

Cinsiyetiniz:

Yaşınız:

\section{BİRINCII KISIM}

Bu bölümde son 1 sene içinde akciğer hastalığınızın ne durumda olduğunu tanımlayacak sorular yer almaktadır. Her soru için kutulardan birini işaretleyiniz.

1-Son bir sene içinde öksürme sıklığım:

$\square$ Haftanın hemen her günü

$\square$ Haftanın çoğu günü

$\square$ Ayda birkaç gün

$\square$ Sadece üşüttüğüm zaman

$\square$ Hiç

2-Son bir sene içindeki balgam çıkarma sıklığım:

$\square$ Haftanın hemen her günü

$\square$ Haftanın çoğu günü

$\square$ Ayda birkaç gün

$\square$ Sadece üşüttüğüm zaman

$\square \mathrm{Hiç}$

3-Son bir sene içinde nefes darlığı durumum:

$\square$ Haftanın hemen her günü

$\square$ Haftanın çoğu günü

$\square$ Ayda birkaç gün

$\square$ Sadece üşüttüğüm zaman 
$\square$ Hiç

4- Son bir sene içinde göğsümde hissettiğim hırıltı-hışıltı sıklığı:

$\square$ Haftanın hemen her günü

$\square$ Haftanın çoğu günü

$\square$ Ayda birkaç gün

$\square$ Sadece üşüttüğüm zaman

$\square$ Hiç 5-Son bir sene içinde kaç defa çok ciddi veya sıkıntı yaratan gögüs hastalığı geçirdiniz?

$\square$ 3'den fazla

$\square 3$ atak

$\square 2$ atak

$\square 1$ defa

$\square$ Hiç

6-En ağır atağınız ne kadar sürdü ? Eğer ağır bir atak geçirmediyseniz 7. Soruya geçiniz.

$\square 1$ hafta veya daha uzun

$\square 3$ gün veya daha uzun

$\square$ 1-2 gün

$\square 1$ günden $\mathrm{az}$

7-Son bir senede, haftada ortalama kaç gün gögüs hastalığınız ile ilgili hiçbir problem olmadan rahat gün geçirdiniz ?

$\square 0$ gün (Haftanın her günü rahatsızdım)

$\square 1$ veya 2 günü rahat geçirdim

$\square 3$ veya 4 günü rahat geçirdim

$\square$ Hemen hemen her gün rahattım

$\square$ Her gün rahattım 8-Göğsünüzde hırıltı-hışıltı varsa bu sabahları kötüleşiyor mu?

$\square$ Evet

$\square$ Hayır

\section{İKINCİ KISIM BÖLÜM-1}

Akciğer hastalığınız ile ilgili durumu nasıl değerlendiriyorsunuz? Lütfen uygun olan kutuyu işaretleyiniz.

$\square$ En önemli problemim 
$\square$ Bana fazla problem yaratıyor

$\square$ Bana az problem yaratıyor

$\square$ Hiç problem yaratmıyor

Eğer bir işte çalışıyorsanız aşağıdakilerden birini işaretleyiniz.

$\square$ Akciğer hastalığım nedeni ile iş hayatım tamamen sona erdi.

$\square$ Akciğer hastalığım nedeni ile işimi yapmam zorlaştı veya işimi değiştirdim.

$\square$ Akciğer hastalığım işimi etkilemiyor

\section{BÖLÜM-2}

Bugünlerde sizde nefes darlığı yapan hareketlerle ilgili sorulardır. Her madde için uygun olan "Doğru” veya "Yanlış" kutusunu işaretleyiniz.

Otururken veya yatarken $\square$ Doğru $\square$ Yanlış

Y1kanırken ve giyinirken $\square$ Doğru $\square$ Yanlış

Ev içinde dolanırken $\square$ Doğru $\square$ Yanlış

Dışarıda düz yolda yürürken $\square$ Doğru $\square$ Yanlış

Merdiven çıkarken $\square$ Doğru $\square$ Yanlış

Yokuş yukarı çıkarken $\square$ Doğru $\square$ Yanlış

Spor yaparken $\square$ Doğru $\square$ Yanlış

\section{BÖLÜM-3}

Bugünlerde olan öksürük ve nefes darlığınızla ilgili soruları içermektedir.

Öksürdüğümde canım acıyor $\square$ Doğru $\square$ Yanlış

Öksürmek beni yoruyor $\square$ Doğru $\square$ Yanlış

Konuşunca nefes nefese kalıyorum $\square$ Doğru $\square$ Yanlış

Öne eğilince nefes nefese kalıyorum $\square$ Doğru $\square$ Yanlış

Öksürük veya nefes darlığım nedeni ile uykum bölünüyor $\square$ Doğru $\square$ Yanlış

Çok çabuk yoruluyorum $\square$ Doğru $\square$ Yanlış

\section{BÖLÜM-4}

Bugünlerde akciğer hastalığınızın sizin üzerinizdeki etkileri ile ilgili sorulardır.

Öksürüğüm veya solunum sıkıntım topluluk içinde utanmama neden oluyor $\square$ Doğru $\square$ Yanlış

Akciğerimle ilgili şikayetlerim yakın çevremi, ailemi, arkadaşlarımı, komşularımı rahatsız ediyor $\square$ Doğru $\square$ Yanlış 
Nefes alamadığım zaman paniğe kapılıyorum veya çok korkuyorum $\square$ Doğru $\square$ Yanlış

Akciğer hastalığımı kontrol altında tutamadığımı düşünüyorum $\square$ Doğru $\square$ Yanlış Akciğerlerimin daha iyi olacağını ummuyorum $\square$ Doğru $\square$ Yanlış

Akciğer hastalığım nedeni ile zayıf, halsiz ve güçsüz biri oldum $\square$ Doğru $\square$ Yanlış Egzersiz yapmaktan kaçınıyorum (Benim için tehlikeli olacağını düşünüyorum) $\square$ Doğru $\square$ Yanlış

Kolumu kaldıracak halim olmadığını hissediyorum $\square$ Doğru $\square$ Yanlış

BÖLÜM-5 Tedaviniz ile ilgili soruları içermektedir. Eğer herhangi bir tedavi almıyorsanız bu bölümü atlayınız ve 6 . Bölüme geçiniz.

Tedavimin faydasını görmüyorum $\square$ Doğru $\square$ Yanlış

İlaçlarımı başkalarının yanında kullanmaktan çekiniyorum $\square$ Doğru $\square$ Yanlış

Tedavimin bazı hoş olmayan yan etkilerini hissediyorum $\square$ Doğru $\square$ Yanlış

Tedavim yaşantımı çok fazla etkiliyor $\square$ Doğru $\square$ Yanlış

\section{BÖLÜM-6}

Bu bölüm; nefes darlınız ile hareketlerinizin ne şekilde kısıtlandığı konusundaki konusundaki soruları içermektedir. Her bir soruda sizin için geçerli olan kutuyu işaretleyiniz.

Y1kanmak veya giyinmek uzun zamanımı alıyor $\square$ Doğru $\square$ Yanlış

Banyo yapamıyorum veya duş alamıyorum, ya da bunlar uzun zamanımı alıyor $\square$ Doğru $\square$ Yanlış

Diğer insanlardan daha yavaş yürüyorum veya dinlenmek için durmak zorunda kalıyorum $\square$ Doğru $\square$ Yanlış

Ev işi gibi faaliyetler uzun zamanımı alıyor, veya dinlenmek için durmak zorunda kalıyorum $\square$ Doğru $\square$ Yanlış

Bir kat merdiven çıkarken yavaş çıkmak veya dinlenmek için durmak zorunda kalıyorum $\square$ Doğru $\square$ Yanlış

Eğer acele edersem veya hızlı yürürsem durup dinlenmek veya yavaşlamak zorunda kalıyorum $\square$ Doğru $\square$ Yanlış

Nefes darlığım nedeni ile yokuş yukarı çıkarken, merdivenden yukarı yük taşırken, çiçek ekmek gibi kolay bahçe işleriyle uğraşırken, dans ederken veya golf oynarken zorlanıyorum v Doğru $\square$ Yanlış 
Nefes darlığım nedeni ile ağır yük taşırken, bahçe kazarken, saatte 5-6 km hızla yürürken, yavaş tempoda koşarken, tenis oynarken veya yüzerken zorlanıyorum $\square$ Doğru $\square$ Yanlış

Nefes darlığım nedeni ile ağır işler yaparken, koşarken bisiklete binerken, hızlı yüzerken veya spor yaparken zorlanıyorum

$\square$ Doğru $\square$ Yanlış

\section{BÖLÜM-7}

Akciğer hastalığınızın günlük yaşamınız üzerinde nasıl etki yaptığını öğrenmek istiyoruz. "Doğru" veya "Yanlış" kutusunu işaretleyiniz. "Doğru” yanıtı verdiğiniz durumların, nefes darlığınız nedeni ile sizi etkileyen faaliyetler olduğunu unutmayınız.

Spor yapamıyorum $\square$ Doğru $\square$ Yanlış

Sosyal etkinlere katılamıyorum $\square$ Doğru $\square$ Yanlış

Alışveriş için dışarıya çıkamıyorum $\square$ Doğru $\square$ Yanlış

Ev işi yapamıyorum $\square$ Doğru $\square$ Yanlış

Yatağımdan, koltuğumdan daha uzak bir yere gidemiyorum $\square$ Doğru $\square$ Yanlış Aşağıda akciğer hastalığınız nedeni ile yapmakta güçlük çekebileceğiniz faaliyetler listelenmiştir. Bu listede yer alan faaliyetleri yapmıyorsanız işaretlemeyiniz. $\mathrm{Bu}$ faaliyetler nefes darlığı nedeniyle yapmakta zorlanabileceğiniz hareketlerden bazılarıdır.

口 Yürüyüşe çıkmak veya köpeği gezdirmek

$\square$ Ev içinde veya bahçede bir şeyler yapmak

$\square$ Cinsel ilişski

$\square$ Camiye gitmek veya bir sosyal aktiviteye katılmak

$\square$ Kötü havada dışarı çıkmak veya dumanlı ortamda bulunmak

$\square$ Aile, arkadaş ziyaretlerinde bulunmak veya çocuklarla oynamak

Yukarıda belirtilenler dışında, akciğer hastalığınız nedeni ile yapamadığınız bir başka aktivite veya önemli faaliyetler varsa burada 
Şimdi, akciğer hastalığınızın sizi nasıl etkilediğini en iyi ifade eden cümleyi işaretleyiniz. Sadece bir seçeneği işaretleyiniz.

$\square$ Hastalığıma rağmen yapmak istediğim her şeyi yapabiliyorum.

$\square$ Hastalığım nedeni ile yapmak istediğim bir iki şeyi yapamıyorum.

$\square$ Hastalığım nedeni ile yapmak istediklerimin çoğunu yapamıyorum.

$\square$ Hastalığım nedeni ile yapmak istediğim hiçbir şeyi yapamıyorum. 
Ek 4. Beck Anksiyete Ölçeği

\section{Beck Anksiyete Ölçeği}

Hastanın Soyadı, Adı:.

Tarih:.

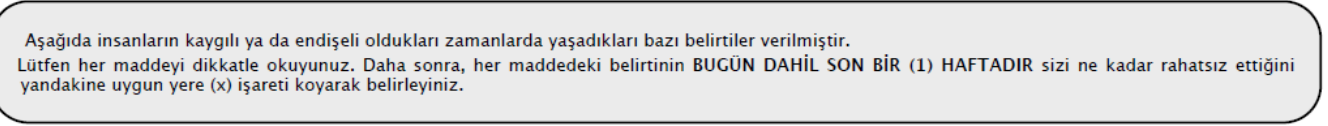

\begin{tabular}{|c|c|c|c|c|}
\hline & Hiç & $\begin{array}{l}\text { Hafif düzeyde } \\
\text { Beni pek et- } \\
\text { kilemedi }\end{array}$ & $\begin{array}{c}\text { Orta düzeyde } \\
\text { Hoș değildi ama k-at } \\
\text { lanabildim }\end{array}$ & $\begin{array}{l}\text { Ciddi düzeyde } \\
\text { Dayanmakta çok zor- } \\
\text { landım }\end{array}$ \\
\hline \multicolumn{5}{|l|}{$\begin{array}{l}\text { 1. Bedeninizin herhangi bir } \\
\text { yerinde uyușma veya karın- } \\
\text { calanma }\end{array}$} \\
\hline \multicolumn{5}{|l|}{ 2. Sıcak/ateş basmaları } \\
\hline \multicolumn{5}{|l|}{ 3. Bacaklarda halsizlik, titreme } \\
\hline \multicolumn{5}{|l|}{ 4. Gevșeyememe } \\
\hline \multicolumn{5}{|l|}{$\begin{array}{l}\text { 5. Çok kötü şeyler olacak } \\
\text { korkusu }\end{array}$} \\
\hline \multicolumn{5}{|l|}{ 6. Baş dönmesi veya sersemlik } \\
\hline \multicolumn{5}{|l|}{ 7. Kalp çarpıntısı } \\
\hline \multicolumn{5}{|l|}{ 8. Dengeyi kaybetme duygusu } \\
\hline \multicolumn{5}{|l|}{ 9. Dehșete kapılma } \\
\hline \multicolumn{5}{|l|}{ 10. Sinirlilik } \\
\hline \multicolumn{5}{|l|}{$\begin{array}{l}\text { 11. Boğuluyormuş gibi olma } \\
\text { duygusu }\end{array}$} \\
\hline \multicolumn{5}{|l|}{ 12. Ellerde titreme } \\
\hline \multicolumn{5}{|l|}{ 13. Titreklik } \\
\hline \multicolumn{5}{|l|}{ 14. Kontrolü kaybetme korkusu } \\
\hline \multicolumn{5}{|l|}{ 15. Nefes almada güçlük } \\
\hline \multicolumn{5}{|l|}{ 16. Ölüm korkusu } \\
\hline \multicolumn{5}{|l|}{ 17. Korkuya kapılma } \\
\hline \multicolumn{5}{|l|}{$\begin{array}{l}\text { 18. Midede hazımsızlık ya da } \\
\text { rahatsızlık hissi }\end{array}$} \\
\hline \multicolumn{5}{|l|}{ 19. Baygınlık } \\
\hline \multicolumn{5}{|l|}{ 20. Yüzün kızarması } \\
\hline $\begin{array}{l}\text { 21. Terleme (sıcaklığa bağlı } \\
\text { olmayan) }\end{array}$ & & & & \\
\hline
\end{tabular}

Toplam BECK-A skoru: 
Ek 5. Beck Depresyon Ölçeği

\section{Beck Depresyon Ölçeği}

Bu form son bir (1) hafta içerisinde kendinizi nasıl hissettiğinizi araştırmaya yönelik 21 maddeden oluşmaktadır. Her maddenin karşısındaki dört cevabı dikkatlice okuduktan sonra, size en çok uyan, yani sizin durumunuzu en iyi anlatanı işaretlemeniz gerekmektedir.

$1 \square$ (0) Üzgün ve sıkıntılı değilim.

글 (1) Kendimi üzüntülü ve sıkıntılı hissediyorum.

口 (2) Hep üzüntülü ve sıkıntılıyım. Bundan kurtulamıyorum.

․ (3) O kadar üzgün ve sıkıntılıyım ki, artık dayanamıyorum.

$2 \square(0)$ Gelecek hakkında umutsuz ve karamsar değilim.

(1) Gelecek için karamsarım.

口 (2) Gelecekten beklediğim hiçbir şey yok.

- (3) Gelecek hakkında umutsuzum ve sanki hiçbir şey düzelmeyecekmiş gibi geliyor.

$3 \square$ (0) Kendimi başarısız biri olarak görmüyorum.

口. (1) Başkalarından daha başarısız olduğumu hissediyorum.

口 (2) Geçmişe baktığımda başarııızlıklarla dolu olduğunu görüyorum.

ㅁ (3) Kendimi tümüyle başarısız bir insan olarak görüyorum.

4 (0) Herşeyden eskisi kadar zevk alıyorum.

口 (1) Birçok şeyden eskiden olduğu gibi zevk alamıyorum.

口 (2) Artık hiçbir şey bana tam anlamıyla zevk vermiyor.

口 (3) Herşeyden sıkılıyorum.

$5 \quad$ (0) Kendimi herhangi bir biçimde suçlu hissetmiyorum.

- (1) Kendimi zaman zaman suçlu hissediyorum.

口 (2) Çoğu zaman kendimi suçlu hissediyorum.

․ (3) Kendimi her zaman suçlu hissediyorum.

6 (0) Kendimden memnunum.

(1) Kendimden pek memnun değilim.

(2) Kendime kızgınım.

(3) Kendimden nefrete ediyorum.

$7 \square$ (0) Başkalarından daha kötü olduğumu sanmıyorum.

口 (1) Hatalarım ve zayıf taraflarım olduğunu düşünmüyorum.

口 (2) Hatalarımdan dolayı kendimden utanıyorum.

ㅁ (3) Herşeyi yanlış yapıyormuşum gibi geliyor ve hep kendimi kabahat buluyorum.

$8 \square(0)$ Kendimi öldürmek gibi düşüncülerim yok.

口 (1) Kimi zaman kendimi öldürmeyi düşündüğüm oluyor ama yapmıyorum.

ㄱ (2) Kendimi öldürmek isterdim.

(3) Fırsatını bulsam kendimi öldürürüm.

9 (0) Içimden ağlamak geldiği pek olmuyor.

(1) Zaman zaman içimden ağlamak geliyor.

口 (2) Çoğu zaman ağlıyorum.

(3) Eskiden ağlayabilirdim ama şimdi istesem de ağlayamıyorum.

10 (0) Her zaman olduğumdan daha canı sıkkın ve sinirli değilim.

- (1) Eskisine oranla daha kolay canım sıkılıyor ve kızıyorum.

(2) Herşey canımı sıkıyor ve kendimi hep sinirli hissediyorum.

(3) Canımı sıkan şeylere bile artık kızamıyorum. 
Ek 6. Sağlık Değerlendirme Anketi HAQ

\section{SAĞUKDEĞERIENDIRME ANKETI}

Așağıda belirtilenleri yapabiliyor musunuz?

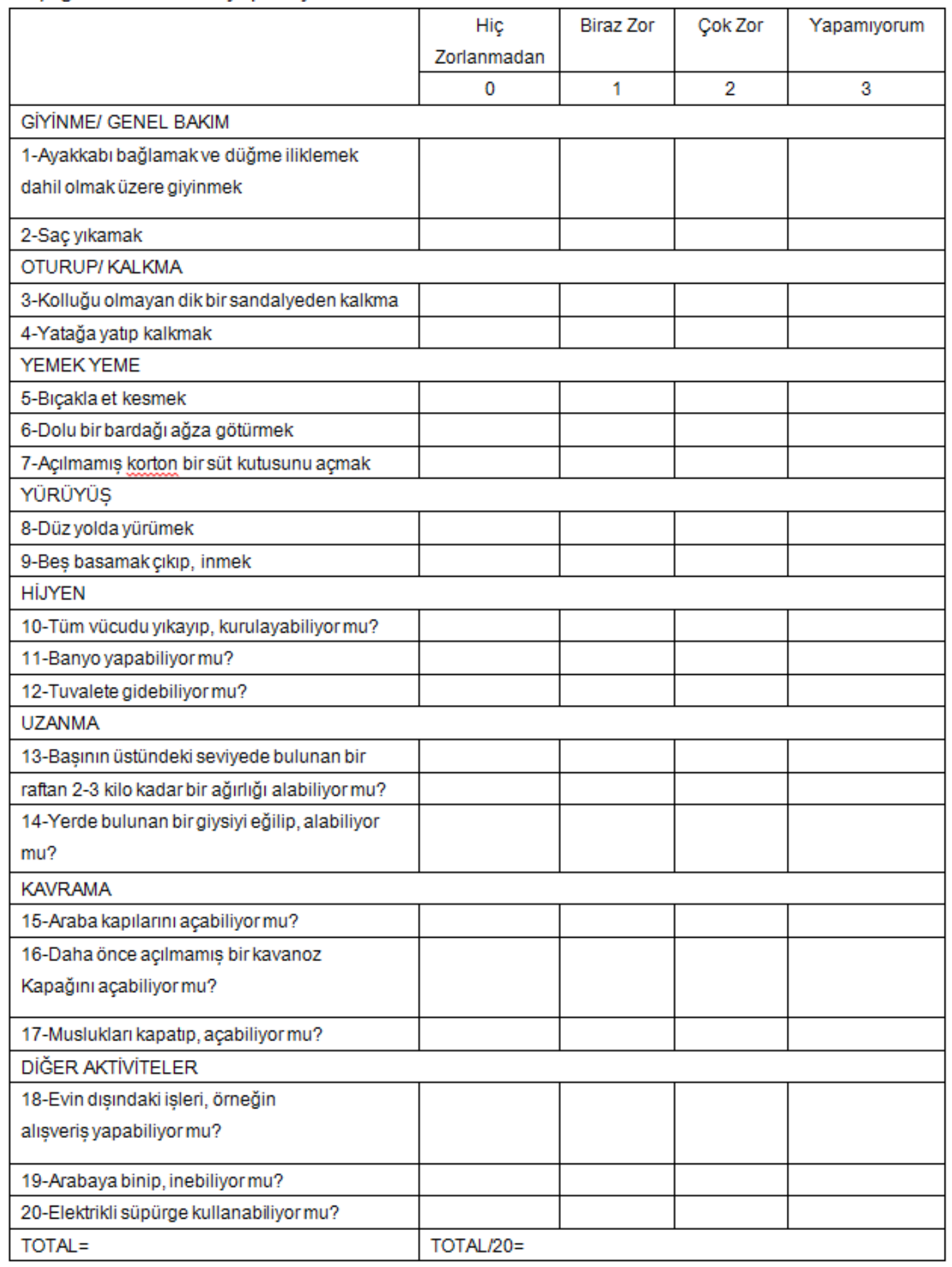


EK 7. SF-36 Yaşam Kalitesi Ölçeği

Adı-Soyadı:

YAŞAM KALİTESİ ÖLÇEĞİ

Tarih:

1. Genel sağlığınızı nasıl değerlendirirsiniz?

\begin{tabular}{|l|c|}
\hline & Bir tanesini yuvarlak içine alınız \\
\hline Mükemmel & 1 \\
\hline Çok iyi & 2 \\
\hline İyi & 3 \\
\hline Orta & 4 \\
\hline Kötü & 5 \\
\hline
\end{tabular}

2. Gecen yıl ile karșlaștırıldığında, sağlığınızı şu an için nasıl değerlendirirsiniz?

\begin{tabular}{|l|c|}
\hline & Bir tanesini yuvarlak içine alınız \\
\hline Geçen seneden çok daha iyi & 1 \\
\hline Geçen seneden biraz daha iyi & 2 \\
\hline Geçen sene ile aynı & 3 \\
\hline Geçen seneden biraz daha kötü & 4 \\
\hline Geçen seneden çok daha kötü & 5 \\
\hline
\end{tabular}


3. Aşağıdaki tipik bir günümüzde yapmış olabileceğiniz bazı aktiviteler yazılmıştır.

Sağlığınız bunları yaparken sizi sınırlandırmakta mıdır? Öyleyse ne kadar?

\begin{tabular}{|l|c|c|c|}
\hline & \multicolumn{3}{|c|}{ Bir tanesini yuvarlak içine alınız } \\
\hline AKTİiTELER & $\begin{array}{c}\text { Evet, çok } \\
\text { kısıtlıyor }\end{array}$ & $\begin{array}{c}\text { Evet, çok } \\
\text { az } \\
\text { kısıtlıyor }\end{array}$ & $\begin{array}{c}\text { Hayır, hiç } \\
\text { Kısıtlamıor }\end{array}$ \\
\hline $\begin{array}{l}\text { a. Kuvvet gerektiren aktiviteler, koşma, } \\
\text { ağır eşyaları kaldırmak, zor sporlar }\end{array}$ & 1 & 2 & 3 \\
\hline $\begin{array}{l}\text { b. Orta aktiviteler, bir masayı oynatmak, } \\
\text { elektrik süpürgesi ile süpürmek, bowling, } \\
\text { golf }\end{array}$ & 1 & 2 & 3 \\
\hline c. Sebze-meyveleri kaldırmak, taşımak & 1 & 2 & 3 \\
\hline d. Pek çok katı çıkmak & 1 & 2 & 3 \\
\hline e. Tek katı çıkmak & 1 & 2 & 3 \\
\hline f. Çömelmek, diz çökmek, eğilmek & 1 & 2 & 3 \\
\hline g. 1 kilometreden fazla yürüyebilmek & 1 & 2 & 3 \\
\hline h. Pek çok mahalle arası yürüyebilmek & 1 & 2 & 3 \\
\hline i. Bir mahalleden (sokak) diğerine yürümek & 1 & 2 & 3 \\
\hline j. Kendi kendine yıkanmak, giyinmek & 1 & 2 & 3 \\
\hline
\end{tabular}

4. Son 4 hafta içerisinde, fiziksel sağlığınız yüzünden günlük iş veya aktivitelerinizde aşağıdaki problemlerle karşılaştınız mı?

\begin{tabular}{|l|c|c|}
\hline & \multicolumn{2}{|c|}{$\begin{array}{c}\text { Bir tanesini yuvarlak içine } \\
\text { alınız }\end{array}$} \\
\hline \multicolumn{1}{|l|}{$\begin{array}{l}\text { EVET } \\
\text { zamânda kesinti }\end{array}$} & 1 & 2 \\
\hline $\begin{array}{l}\text { b. İstediğinizden daha az miktar işin tamamlanması } \\
\text { c. İşin veya diğer aktivitelerin çeşidinde kısıtlama }\end{array}$ & 1 & 2 \\
\hline d. İş veya diğer aktiviteleri yaparken zorluk olması & 1 & 2 \\
\hline
\end{tabular}


5. Son 4 hafta içerisinde, duygusal problemler (örnek-üzüntü ya da sinirli hissetmek) yüzünden günlük iş veya aktivitelerinizde aşağıdaki problemlerle karşılaştınız mı?

\begin{tabular}{|l|c|c|}
\hline & \multicolumn{2}{|c|}{$\begin{array}{c}\text { Bir tanesini yuvarlak içine } \\
\text { alınız }\end{array}$} \\
\hline & EVET & HAYIR \\
\hline $\begin{array}{l}\text { a. İş ya da diğer aktiviteler ayırdığınız süreden } \\
\text { kesilme oldu mu? }\end{array}$ & 1 & 2 \\
\hline $\begin{array}{l}\text { b. İstediğinizden daha az kısım tamamlanması } \\
\begin{array}{l}\text { c. İşin veya diğer aktiviteleri eskisi gibi dikkatli } \\
\text { yapmama }\end{array}\end{array}$ & 1 & 2 \\
\hline
\end{tabular}

6. Geçen 4 hafta içinde, fiziksel sağlık veya duygusal problemler, aileniz, arkadaşınız, komşularınız veya gruplar ile olan normal sosyal aktivitelerinize ne kadar engel oldu?

\begin{tabular}{|l|c|}
\hline & Bir tanesini yuvarlak içine alınız \\
\hline Hiç & 1 \\
\hline Çok az & 2 \\
\hline Orta derecede & 3 \\
\hline Biraz & 4 \\
\hline Oldukça & 5 \\
\hline
\end{tabular}

7. Son 4 hafta içerisinde, ne kadar fiziksel acı(ağrı) hissettiniz?

\begin{tabular}{|l|c|}
\hline & Bir tanesini yuvarlak içine alınız \\
\hline Hiç & 1 \\
\hline Çok az & 2 \\
\hline Orta & 3 \\
\hline Çok & 4 \\
\hline İleri derecede & 5 \\
\hline Çok şiddetli & 6 \\
\hline
\end{tabular}


8. Son 4 hafta içerisinde, ağrı normal işinize ne kadar engel oldu?

\begin{tabular}{|l|c|}
\hline & Bir tanesini yuvarlak içine alınız \\
\hline Hiç & 1 \\
\hline Çok az & 2 \\
\hline Orta & 3 \\
\hline Çok & 4 \\
\hline İleri derecede & 5 \\
\hline
\end{tabular}

9. Aşağıdaki sorular sizin son 4 hafta içerisinde kendinizi nasıl hissettiğiniz ve işlerin nasıl gittiği ile ilgilidir. Lütfen her soru için hissettiğinize en yakın olan sadece 1 cevap verin.

\begin{tabular}{|l|c|c|c|c|c|c|}
\hline & \multicolumn{5}{|c|}{ Bir tanesini yuvarlak içine alınız } \\
\hline & $\begin{array}{c}\text { Her } \\
\text { Zaman }\end{array}$ & $\begin{array}{c}\text { Çoğu } \\
\text { Zaman }\end{array}$ & $\begin{array}{c}\text { Bir } \\
\text { Kısım }\end{array}$ & Bazen & $\begin{array}{c}\text { Çok } \\
\text { Nadir }\end{array}$ & $\begin{array}{c}\text { Hiçbir } \\
\text { Zaman }\end{array}$ \\
\hline $\begin{array}{l}\text { a.Kendinizi capcanlı hissediyor } \\
\text { musunuz? }\end{array}$ & 1 & 2 & 3 & 4 & 5 & 6 \\
\hline $\begin{array}{l}\text { b. Çok sinirli bir kişi misiniz? } \\
\text { c.Kendinizi hiçbir şey } \\
\text { güldürmeyecek kadar batmış } \\
\text { hissediyor musunuz? }\end{array}$ & 1 & 2 & 3 & 4 & 5 & 6 \\
\hline $\begin{array}{l}\text { d.Kendinizi sakin ve huzurlu } \\
\text { hissettiniz mi? }\end{array}$ & 1 & 2 & 3 & 4 & 5 & 6 \\
\hline $\begin{array}{l}\text { e. Çok enerjiniz var mı? } \\
\text { f.Kendinizi çökmüş ve karamsar } \\
\text { hissettiniz mi? }\end{array}$ & 1 & 2 & 3 & 4 & 5 & 6 \\
\hline g. Yıpranmış hissettiniz mi? & 1 & 2 & 3 & 4 & 5 & 6 \\
\hline h. Mutlu bir insan mıydınız? & 1 & 2 & 3 & 4 & 5 & 6 \\
\hline i. Yorulmuş hissettiniz mi? & 1 & 2 & 3 & 4 & 5 & 6 \\
\hline
\end{tabular}


10. Geçen 4 hafta içende, fiziksel sağlık veya duygusal problemler, sosyal aktivitelerinize (arkadaşları, akrabaları ziyaret etmek gibi) ne kadar engel oldu?

\begin{tabular}{|l|c|}
\hline & Bir tanesini yuvarlak içine alınız \\
\hline Her zaman & 1 \\
\hline Çoğu zaman & 2 \\
\hline Bazı zamanlarda & 3 \\
\hline Çok az zaman & 4 \\
\hline Hiçbir zaman & 5 \\
\hline
\end{tabular}

11. Aşağıdaki cümleler sizin için ne kadar doğru ya da yanlış?

\begin{tabular}{|l|c|c|c|c|c|}
\hline & \multicolumn{5}{|c|}{ Bir tanesini yuvarlak içine alınız } \\
\hline & $\begin{array}{c}\text { Tamamen } \\
\text { Doğru }\end{array}$ & $\begin{array}{c}\text { Çoğunlukla } \\
\text { Doğru }\end{array}$ & Bilmiyorum & $\begin{array}{c}\text { Çoğunlukla } \\
\text { Yanlış }\end{array}$ & $\begin{array}{c}\text { Tamamen } \\
\text { Yanlış }\end{array}$ \\
\hline $\begin{array}{l}\text { a. Diğer } \\
\text { insanlardan biraz } \\
\text { daha kolay hasta } \\
\text { oluyorum }\end{array}$ & 1 & 2 & 3 & 4 & 5 \\
\hline $\begin{array}{l}\text { b. Tanıdığım } \\
\text { herkes kadar } \\
\text { sağlıklıyım }\end{array}$ & 1 & 2 & 3 & 4 & 5 \\
\hline $\begin{array}{l}\text { c.Sağlığımın } \\
\text { kötüleşmesini } \\
\text { bekliyorum }\end{array}$ & 1 & 2 & 3 & 4 & 5 \\
\hline $\begin{array}{l}\text { d. Sağlığım } \\
\text { mükemmel }\end{array}$ & 1 & 2 & 3 & 4 & 5 \\
\hline
\end{tabular}


EK 8. Etik Kurul Formu

KLINIIK ARAŞTIRMALAR ETIKK KURULU KARAR FORMU

\begin{tabular}{|l|l|}
\hline ARAŞTIRMANIN AÇIK ADI & $\begin{array}{l}\text { Aktif Egzersiz Ĕ̆itimi ve Ekstansör Strt Korsesinin KOAH'l } \\
\text { Hastalardaki Kemik Yoğunluğu, Kas Kuvveti, Egzersiz } \\
\text { Kapasitesi ve Yaşam Kalitesine Olan Etkilerinin Incelenmesi }\end{array}$ \\
\hline VARSA ARAŞTIRMANIN PROTOKOL KODU & \\
\hline
\end{tabular}

\begin{tabular}{|c|c|c|c|c|c|}
\hline \multirow{5}{*}{ 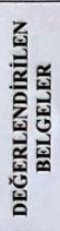 } & Belge Adı & Tarihi & $\begin{array}{l}\text { Versiyon } \\
\text { Numarast }\end{array}$ & \multicolumn{2}{|c|}{ Dili } \\
\hline & ARAȘTIRMA PROTOKOLƠ & & & Turkse $\boldsymbol{Q}$ Ingilizce $\square$ & Diger $\square$ \\
\hline & $\begin{array}{l}\text { BILGILENDIRILMIȘ GONOÚLLƠ OLUR } \\
\text { FORMU }\end{array}$ & & & Turkce $\otimes \quad$ Ingilizce $\square$ & Diger $\square$ \\
\hline & OLGU RAPOR FORMU & & & Torkçe $\square \quad$ Ingilizce $\square$ & Diger $\square$ \\
\hline & ARAȘTIRMA BROŞŨ & & & Torkse $\square \quad$ Ingilizce $\square$ & Diger $\square$ \\
\hline \multirow{9}{*}{ 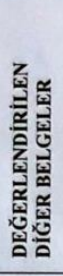 } & Belge Adt & & \multicolumn{3}{|c|}{ Açıklama } \\
\hline & SIGORTA & $\square$ & & & \\
\hline & ARASTTIRMA BÖTCCESI & $\square$ & & & \\
\hline & $\begin{array}{l}\text { BYYOLOJIK MATERYEL TRANSFER } \\
\text { FORMU }\end{array}$ & $\square$ & & & \\
\hline & ILAN & $\square$ & & & \\
\hline & 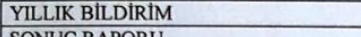 & 믐 & & & \\
\hline & SONUC RAPORU & $\bar{\square}$ & & & \\
\hline & GOOVENLILIK BILDIRIMLERI & प्र & & & \\
\hline & DiĞER: & $\square$ & & & \\
\hline \multirow[b]{2}{*}{ 运产 } & Karar No: 2018/05 & \multicolumn{4}{|l|}{ Tarih: 06.06.2 } \\
\hline & \multicolumn{5}{|c|}{ 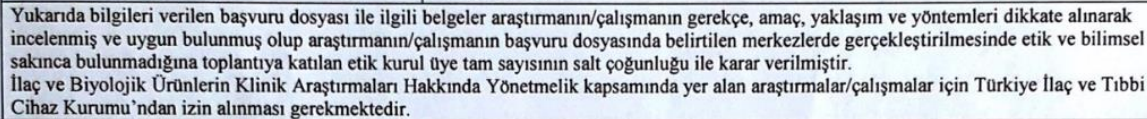 } \\
\hline
\end{tabular}

\begin{tabular}{|l|l|}
\hline \multicolumn{2}{|c|}{ KLíiNiK ARAŞTIRMALAR ETiK KURULU } \\
\hline ETiK KURULUN ÇALIŞMA ESASI & llą̧ ve Biyolojik Orunlerin Klinik Araştırmaları Hakkında Yơnetmelik, Iyi Klinik Uygulamaları Kılavuzu \\
\hline BAŞKANIN UNVANI/ ADI / SOYADI: & Dr. Öğr.Öyesi Nebiye YAŞAR \\
\hline
\end{tabular}

\begin{tabular}{|c|c|c|c|c|c|c|c|c|c|}
\hline \multirow{2}{*}{$\begin{array}{r}\text { Unvanı/Adı/Soyadı } \\
\text { Prof.Dr. Kemal ARIKAN }\end{array}$} & \multirow{2}{*}{$\begin{array}{l}\text { Uzmanlık Alanı } \\
\text { Psikiyatri }\end{array}$} & \multirow{2}{*}{$\begin{array}{r}\text { Kurumu } \\
\text { Ôskudar Ôniversitesi }\end{array}$} & \multicolumn{2}{|c|}{ Cinsiyet } & \multicolumn{2}{|c|}{$\begin{array}{c}\text { Arasstırma ile } \\
\text { ilişki }\end{array}$} & \multicolumn{2}{|c|}{ Katllım * } & \multirow{2}{*}{ İmza } \\
\hline & & & $\mathrm{E} \otimes$ & к० & ED & $\mathrm{H} \otimes$ & ED & $\mathrm{H} \otimes$ & \\
\hline Prof. Dr. Hüsnü ERKMEN & Psikiyatri & Oskudar Oniversitesi & $\mathrm{E} \otimes$ & к० & $\mathrm{E} \square$ & $\mathrm{H} \otimes$ & $\mathrm{E} \otimes$ & $\mathrm{H} \square$ & \\
\hline Prof. Dr. Ali Oğuz TANRIDAĞ & Nơroloji & Oskudar Ôniversitesi & $\mathrm{E} \otimes$ & Kप & $\mathrm{E} \square$ & $\mathrm{H} \otimes$ & $\mathrm{E} \otimes$ & $\mathrm{H}_{\mathrm{f}}$ & \\
\hline Prof. Dr. Yaşar KESKín & Halk Sağığı̆ & Marmara Oniversitesi & $\mathrm{E} \otimes$ & $\mathrm{K} \square$ & ED & $\mathrm{H} \otimes$ & ED & $\mathrm{H} \otimes$ & \\
\hline Prof. Dr. Esra SAĞLAM & Tibbi Farmakoloji & $\begin{array}{l}\text { Maltepe Oniversitesi tip } \\
\text { Fakultesi }\end{array}$ & E口 & $\mathrm{K} \otimes$ & $\mathrm{E} \square$ & $\mathrm{H} \otimes$ & $\mathrm{E} \otimes$ & н & \\
\hline Prof. Dr. Hanzade DOĞAN & Tip Etigi & Cerrahpaşa Universitesi & ED & $\mathrm{K} \otimes$ & ED & $\mathrm{H} \boldsymbol{\nabla}$ & $\mathrm{E} \otimes$ & н口 & \\
\hline Doç. Dr. Barış METiN & Nơroloji & Öskudar Oniversitesi & $\mathrm{E} \otimes$ & к० & $\mathrm{E} \square$ & $\mathrm{H} \otimes$ & ED & $\mathrm{H} \otimes$ & \\
\hline Uzm. Dr. Celal ŞALÇini & Noroloji & $\begin{array}{l}\text { NPISTANBULL Beyin } \\
\text { Hastanesi }\end{array}$ & $\mathrm{E} \otimes$ & к & $\mathrm{E} \square$ & $\mathrm{H} \otimes$ & $\mathrm{E} \otimes$ & н口 & \\
\hline Dr. Ali BAYRAM & $\begin{array}{l}\text { Biyomedikal } \\
\text { Mahendisligi }\end{array}$ & Istanbul Oniversitesi & $\mathrm{E} \otimes$ & K & ED & $\mathrm{H} \otimes$ & $\mathrm{E} \otimes$ & $\mathrm{HO}$ & \\
\hline Dr. Ögr. Üyesi Nebiye YAŞAR & $\begin{array}{l}\text { Sağlik Mensubu } \\
\text { Olmayan Óye }\end{array}$ & Ôskudar Ôniversitesi & ED & $\mathrm{K} \boldsymbol{\nabla}$ & ED & $\mathrm{H} \boldsymbol{\nabla}$ & $\mathrm{E} \boldsymbol{\nabla}$ & H口 & \\
\hline Av. Cüneyd DOĞAN & Hukukq̧u & Y\&G Hukuk Bürosu & $\mathrm{E} \otimes$ & K 口 & ED & $\mathrm{H} \otimes$ & $\mathrm{E} \otimes$ & н & \\
\hline
\end{tabular}

Etik Kłarul Başkan V.

Unvarı/Adı/Soyadı: Dr. Öğr. Üyesi Nebiye YAŞAR

İmza: 


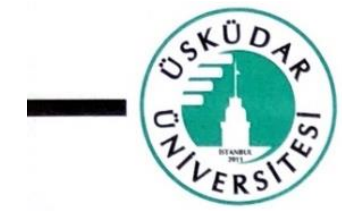

Altunizade Mahallesi Haluk Türksoy Sokak No:14 34662 Üsküdar/ISTANBUL T: 02164002222 F: 02164741256 bilgiduskudar edut T.C.

ÜSKÜDAR ÜNIVERSITESI

KLINIKK ARASTIRMALAR

ETIKK KURULU BAŞKANLIĞI

SAYI: $61351342 / 2018 / 09$

07/06/2018

\section{İLGİLİ MAKAMA}

Prof. Dr. Filiz CAN (Sorumlu Araştırmacı), Fatma Fulden ŞAHMAN ÇAKIR (Yardımcı Araştırıcı) tarafindan, Üsküdar Üniversitesi Klinik Araştırmalar Etik Kurulu'na başvurusu yapılmıș olan “Aktif Egzersiz Eğitimi ve Ekstansör Sırt Korsesinin KOAH’lı Hastalardaki Kemik Yoğunluğu, Kas Kuvveti, Egzersiz Kapasitesi ve Yaşam Kalitesine Olan Etkilerinin Incelenmesi' adlı araștırma önerisi, kurulumuzun 06 Haziran 2018 tarihli, 05 No.lu toplantısında değerlendirilerek, çalışmanın başvuru dosyasında belirtilen merkezlerde gerçekleștirilmesinde etik ve bilimsel sakınca bulunmadığına oy birliği ile karar verilmiștir.

Bilgilerinize rica ederim

Dr. Öğr. Üyesi Nebiye Y̧AȘAR

Klinik Araştırmalar Etik Kurıl \$aş̧an Yardımcısı 
'STABIL DURUMDAKI KOAH HASTALARINDA SOLUNUM FONKSIYYONLARI, EGZERSIZ KAPASITESI, YAŞAM KALITESI, ANKSIYYTE ILE BİRLIKTE AĞRI, KAS KUVVETİ VE KEMİK MINERAL YOĞUNLUĞUNUN İNCELENMESI' ÇALIŞMASI İÇIN AYDINLATILMIŞ (BİLGILENDİRILLMIŞ) ONAM FORMU

(Fizyoterapistin Beyanı)

Stabil durumdaki KOAH hastalarında solunum fonksiyonları, egzersiz kapasitesi, yaşam kalitesi, anksiyete ile birlikte ağrı, kas kuvveti ve kemik mineral yoğunluğunun incelenmesi için klinik ve bilimsel çalışmalara yol gösterecek yeni bir çalışma yapmaktayız.

İstanbul LiV Hospital Göğüs Hastalıkları Polikliniği ve Bahçeşehir Üniversitesi, Sağlık Bilimeri Fakültesi, Fizik Tedavi ve Rehabilitasyon Bölümü'nün ortak katılımı ile gerçekleştirilecek bu çalışmaya katılmanızı öneriyoruz. Ancak hemen söyleyelim ki bu araştırmaya katılıp katılmamakta serbestsiniz. Çalışmaya katılım gönüllülük esasına dayalıdır. Kararınızdan önce araştırma hakkında sizi bilgilendirmek istiyoruz. $\mathrm{Bu}$ bilgileri okuyup anladıktan sonra araştırmaya katılmak isterseniz formu imzalayınız.

Eğer araştırmaya katılmayı kabul ederseniz Fzt. Fulden ŞAHMAN ÇAKIR tarafından solunum,kas kuvvetiniz ve egzersiz kapasiteniz değerlendirilecek, egzersiz kapasitenizi ve günlük yaşam aktivitelerinde yaşadığınız zorlukları değerlendirmek için çeşitli performans testleri yapılacaktır. Ayrıca günlük yaşam aktivitelerinizde nefes darlığı veya diğer semptomlara bağlı kısıtlılıklarınızı ve hastalığın yaşam kalitenizi ne kadar etkilediğini değerlendirmek için çeşitli anketler uygulanacaktır. Yine izniniz doğrultusunda değerlendirmeleri fotoğraf ya da video kaydı ile belgelemek istemekteyiz. Bu kayıtlar ilerde tekrar incelenecektir. Bu kayıtlar kimliğiniz belirtilmeden fizyoterapi ve rehabilitasyon bölümü öğrencilerinin eğitiminde veya bilimsel nitelikte yayınlarda kullanılabilir. Bu amaçların dışında bu kayıtlar kullanılmayacak ve başkalarına verilmeyecektir.

Çalışmaya İstanbul LIV Hospital Gögüs Hastalıkları Polikliniği tarafindan hafif şiddetli-orta şiddetli kronik obstrüktif akciğer hastalığı tanısı konulan 40-70 yaş arası hastalar dahil edilecektir.

$\mathrm{Bu}$ çalışmaya katılmanız için sizden herhangi bir ücret istenmeyecektir. Çalışmaya katıldığınız için size ek bir ödeme de yapılmayacaktır. 
Sizinle ilgili tıbbi bilgiler gizli tutulacak, ancak çalışmanın kalitesini denetleyen görevliler, etik kurullar ya da resmi makamlarca gereği halinde incelenebilecektir.

Değerlendirme sırasında oluşabilecek riskler: Düşünülen herhangi bir risk bulunmamaktadır. $\mathrm{Bu}$ çalışmaya katılmayı reddedebilirsiniz. $\mathrm{Bu}$ araştırmaya katılmak tamamen isteğe bağlıdır ve reddettiğiniz takdirde size uygulanan tedavide herhangi bir değişiklik olmayacaktır. Yine çalışmanın herhangi bir aşamasında onayınızı çekmek hakkına da sahipsiniz.

\section{(Katılımcının/Hastanın Beyanı)}

Sayın Fulden ŞAHMAN ÇAKIR tarafindan İstanbul LIV Hospital Göğüs Hastalıkları Polikliniği ve Bahçeşehir Üniversitesi, Sağlık Bilimeri Fakültesi, Fizik Tedavi ve Rehabilitasyon Bölümü’nün ortak katılımı ile tıbbi bir araştırma yapılacağı belirtilerek bu araştırma ile ilgili yukarıdaki bilgiler bana aktarıldı. Bu bilgilerden sonra böyle bir araştırmaya "katılımcı" (denek) olarak davet edildim.

Eğer bu araştırmaya katılırsam fizyoterapist ile aramda kalması gereken bana ait bilgilerin gizliliğine bu araştırma sırasında da büyük özen ve saygı ile yaklaşılacağına inanıyorum. Araştırma sonuçlarının eğitim ve bilimsel amaçlarla kullanımı sırasında kişisel bilgilerimin ihtimamla korunacağı konusunda bana yeterli güven verildi.

Projenin yürütülmesi sırasında herhangi bir sebep göstermeden araştırmadan çekilebilirim. (Ancak araştırmacıları zor durumda bırakmamak için araştırmadan çekileceğimi önceden bildirmemim uygun olacağının bilincindeyim) Ayrıca tıbbi durumuma herhangi bir zarar verilmemesi koşuluyla araştırmacı tarafından araştırma dişı tutulabilirim.

Araştırma için yapılacak harcamalarla ilgili herhangi bir parasal sorumluluk altına girmiyorum. Bana da bir ödeme yapılmayacaktır.

İster doğrudan, ister dolaylı olsun araştırma uygulamasından kaynaklanan nedenlerle meydana gelebilecek herhangi bir sağlık sorunumun ortaya çıkması halinde, her türlü tıbbi müdahalenin sağlanacağı konusunda gerekli güvence verildi. (Bu tıbbi müdahalelerle ilgili olarak da parasal bir yük altına girmeyeceğim).

Araştırma sırasında bir sağlık sorunu ile karşılaştığımda; herhangi bir saatte, Fzt.Fulden ŞAHMAN ÇAKIR'1 0530 235-80-95 no'lu telefondan arayabileceğimi biliyorum. $\mathrm{Bu}$ araştırmaya katılmak zorunda değilim ve katılmayabilirim. 
Araştırmaya katılmam konusunda zorlayıcı bir davranışla karşılaşmış değilim. Eğer katılmayı reddedersem, bu durumun fizyoterapi programıma ve fizyoterapist ile olan ilişkime herhangi bir zarar getirmeyeceğini de biliyorum.

Bana yapılan tüm açıklamaları ayrıntılarıyla anlamış bulunmaktayım. Kendi başıma belli bir düşünme süresi sonunda adı geçen bu araştırma projesinde "katılımcı" (denek) olarak yer alma kararını aldım. Bu konuda yapılan daveti büyük bir memnuniyet ve gönüllülük içerisinde kabul ediyorum.

İmzalı bu form kağıdının bir kopyası bana verilecektir.

Kat1limc1

Ad1, soyad1: Adres: Tel: İmza:

Görüşme tanı̆̆ 1

Ad1, soyad1: Adres: Tel: İmza:

Katılımcı ile görüşen fizyoterapist

Adı soyadı, unvanı: Fzt. FULDEN ŞAHMAN

Adres: LIV Hospital Göğüs Hastalıkları Polikliniği İSTANBUL

Tel: 0(216) 2308080

İmza:

Sorumlu araştırmac1

Ad1, soyad1: Prof. Dr. Filiz CAN

Adres: : Hacettepe Üniversitesi, Sağlık Bilimleri Fakültesi, Fizyoterapi ve Rehabilitasyon Bölümü, 06100 Samanpazarı / Ankara

Tel: 0(312) 3051576

İmza: 
EK 9. Orjinallik Ekran Çıktısı

\section{Fulden Tez}

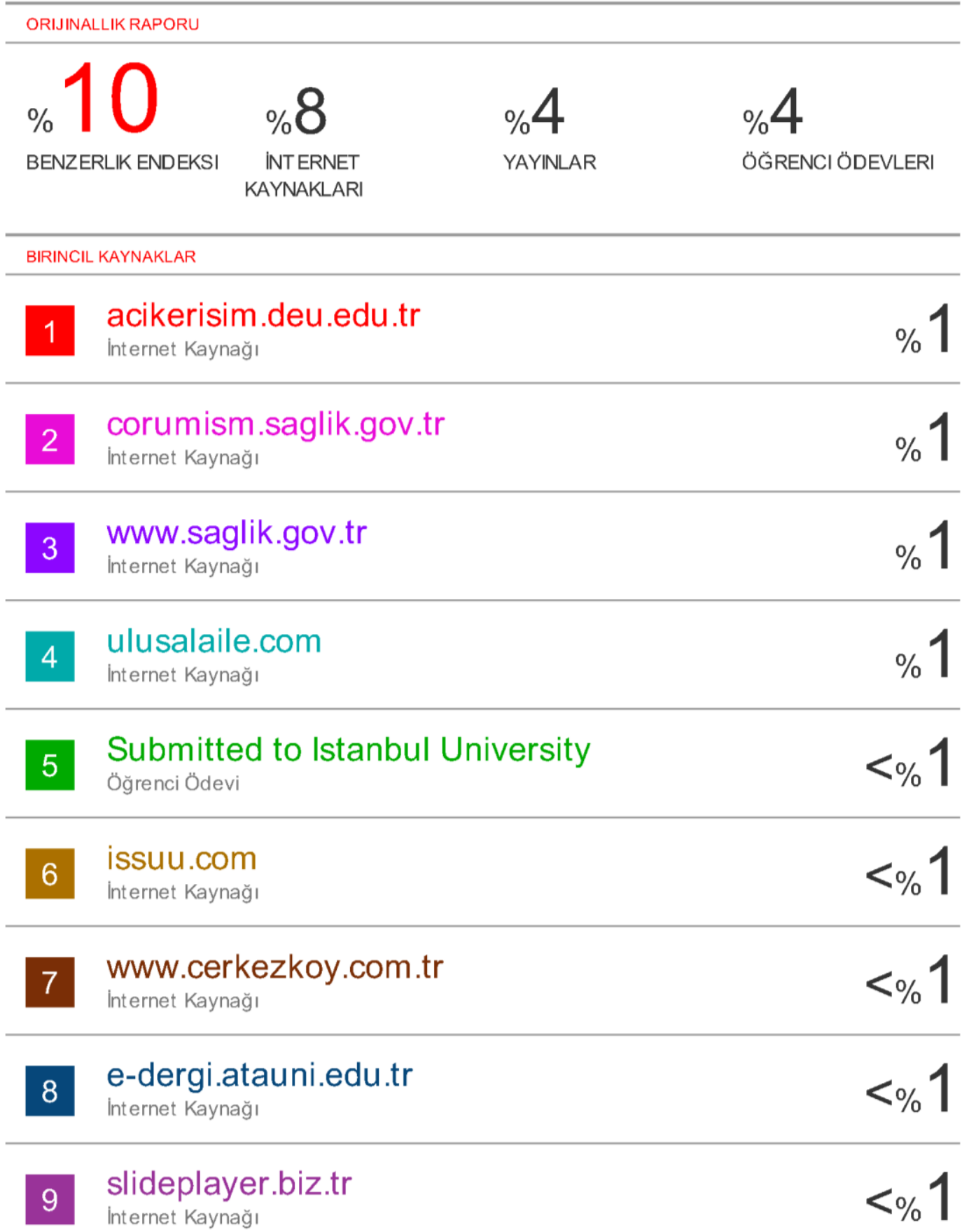


EK 10. Dijital Makbuz

\section{turniting}

\section{Dijital Makbuz}

Bu makbuz ödevinizin Turnitin'e ulaştığını bildirmektedir. Gönderiminize dair bilgiler şöyledir:

Gönderinizin ilk sayf ası aşağıda gönderilmektedir.

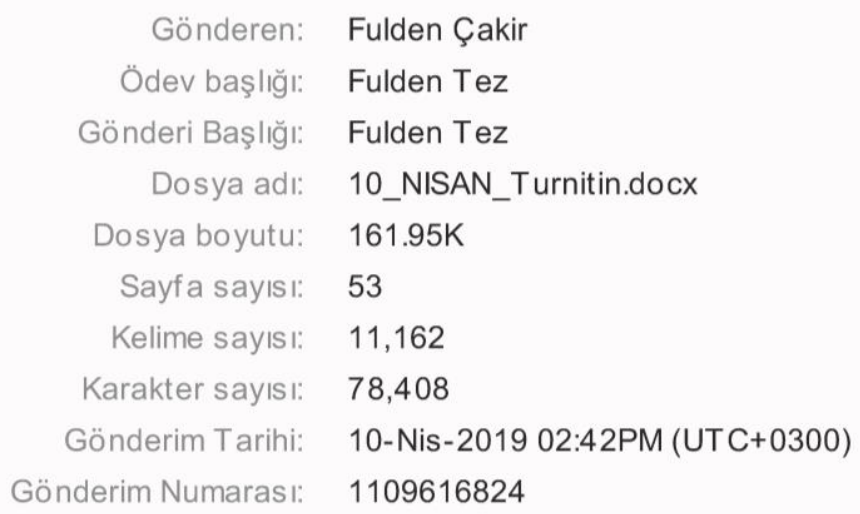




\section{9. ÖZGEÇMIŞ}

\section{F.FULDEN ŞAHMAN ÇAKIR}

Mersin, 1985

Yenibahar sokak Aktas Sitesi Bblok Daire 9 Levazım Beşiktaş_İstanbul EĞİTì

1996-2003 M.T.S.O Anadolu Lisesi, Mersin

2005-2010 Başkent Üniversitesi, Ankara Sağl1k Bilimleri Fakültesi

Fizik Tedavi ve Rehabilitasyon Bölümü

2009 Yaz Dönemi Santa Monica College Dil Eğitim Programı

2009-2011 Anadolu Üniversitesi Açıköğretim Fakültesi Sağlık Kurumları İşletmeciliği

2010-2013 Hacettepe Üniversitesi Sağlık Yüksekokulu Fizik Tedavi ve Rehabilitasyon Bölümü-Protez Ortez Biomekanik Bölümü Yüksek Lisans ÖDÜLLERİ

2005-2010 Başkent Üniversitesi \% 20 Başarı Bursu

\section{SOSYAL AKTIVITTELER}

Başkent Üniversitesi Fizik Tedavi ve Rehabilitasyon Topluluğu Üyesi

Türkiye Fizyoterapistler Birliği Üyesi

Türk Toraks Derneği Üyesi

\section{PROJELER}

Aktif Egzersiz Eğitimi ve Ekstansör Surt Korsesinin Koah'lı Hastalardaki Kemik Yoğunluğu,Kas Kuvveti,Egzersiz Kapasitesi ve Yaşam Kalitesine Olan Etkilerinin İncelenmesi,Fibromyalji ve Kronik Yorgunluk Sendromu

\section{ALDIĞI EĞİTIMMLER}

Ortopedik Manuel Terapi Eğitimi (Üst ekstremite, Alt ekstremite) Ortopedik Manuel Terapi Eğitimi (Omurga) Manuel Trigger Point eğitimi 
Kinesiolojik bantlama eğitimi Refleksoloji

Klinik Pilates

BİLGİ ve BECERİLER

Bilgisayar: Windows,Microsoft World, Exel Powerpoint, SPSS (iyi düzey)

Yabancı Dil: İngilizce (iyi düzey) Almanca (başlangıç)

İŞ DENEYİMI

Başkent Üniversitesi Hastanesi,Ümitköy Polikliniği,Ankara (staj)

Başkent Üniversitesi Erişkin Rehabilitasyon Hastanesi,Ayaş,Ankara(staj)

Başkent Üniversitesi Fizik Tedavi ve Rehabilitasyon Polikliniği,Ankara (staj)

Başkent Üniversitesi Merkez Hastanesi,Ankara (staj)

Hacettepe Üniversitesi Hastanesi ,Protez-Ortez_Biyomekanik Bölümü, Ankara (staj)

T.S.K Güvercinlik Hastanesi Pediatri Bölümü,Ankara (staj)

Mersin Özel Fizyomed Fizik Tedavi ve Rehabilitasyon Polikliniği,Mersin (staj)

Doç.Dr. Albay Sadettin Güngör (Kadın Doğum) Özel Muayenesi,Ankara

(staj)(gebelik pilatesi)

Ankara Özdecan Özel Eğitim Merkezi (Fizyoterapist)

Mersin Metin Uğur Sarıkaya Özel Eğitim Merkezi (Fizyoterapist)

Özel Medistate Hastanesi Kavacık,İstanbul (Baş Fizyoterapist)

LIV Hastanesi,İstanbul(Solunum Fizyoterapisti)

Bahçeşehir Üniversitesi,Fizik Tedavi ve Rehabilitasyon Bölümü, İstanbul (Öğretim Görevlisi) 
